FACULDADE DE SAÚdE PÚBLICA

O MEDICAMENTO COMO PROBLEMA DE SAÚdE PÚBLICA. CONTRIBUIÇÃO PARA O ESTUDO DE UMA MERCADORIA SIMBÓLICA

FERNANDO LEFEVRE

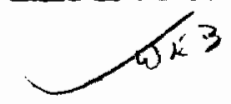

Tese apresentada a Faculdade de Saúde Pública da Universidade de São Paulo para obtenção do título de Foutor em Saúde Pública.

Orientador Profa. Titular NELL YSPAPRATS FERREIRA CANDEIAS WES

\title{
SĀO PAULO
}

1989 


\section{Para Ana}

e seus filhos

Para Camila, Guilherme e Daniel 


\section{AGRADECIMENTOS}

Dra. Nelly Candeias, pela paciência e comprensåo

Huda Farah Siqueira Cunha, pela competência entrevistante

Dr. Hugo Caplan, pela hipertensão

Funcionários e pacientes do Centro de Saúde Geraldo de Paula Souza

Prof.Esdras Costa,pela pesquisa qualitativa

Professora Lucrécia D’Aléssio Ferrara,pela semiótica

Cornélia, pelo inglês.

Dr.Cid Guimarães, Dra.Lourdes de Freitas Carvalho e Dr. Rosemburg,pelo apoio institucional.

Denize, pela ordenação dos capítulos.

Amigos e colegas da Faculdade, pelo apoio intelectual e moral 


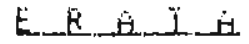

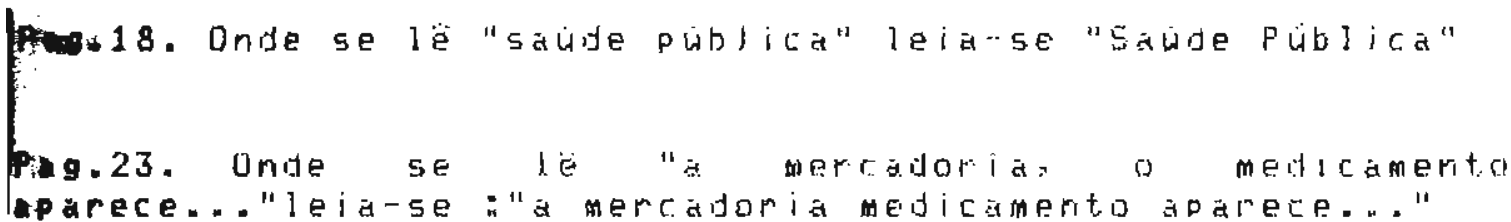

Pag.45. Onde se lë: "contgerem" leja”se "corterem".

Pag.46. Onde se lé "uas das razoes" leia-se "wál bas razos".

Pag.47. Onde se le : "nos procedimentos e nas intepnaboes cotidianas" Ieia-se "nos procediaentos e nas interackes rotidianas".

Pag. 75. Onde se lë: "simbo-dizajo" leia-se "simbojizado".

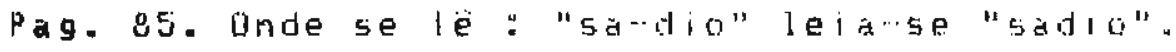

Pag. 92. Onde se le: "ou seja, como obiologico" leia-so

"ou seja, con o biológico".

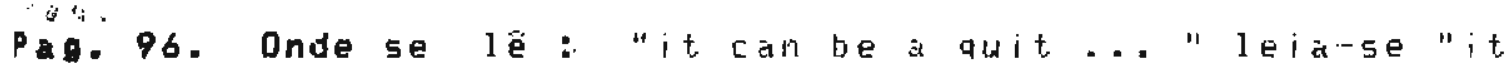
can be a quite..."

Pag. 96. Onde se 1é : "more time" p "the less" leia-se "more time" e the less"

Pag. 112. A bltima frase do primeiro paragrato deve sep sublinhada.

Pag. 113. No final Jo quarto paragrato existen apenas agis enteristicos a ná quatron

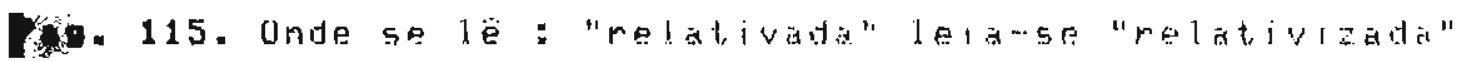




\section{INDICE}

\section{RESUMO}

\section{SUMMARY}

I - INTRODUÇÃO_....................................................................................................................................12

1. Definição do problema ...................................................................................................................12

2. O problema no contexto das visões de Saúde .....................................................................20

3. O problema e sua pertinência para a Educação em Saúde Pública...............................25

II - PRESSUPOSTOS TEORICO-METODOLOGICOS ….....................................................28

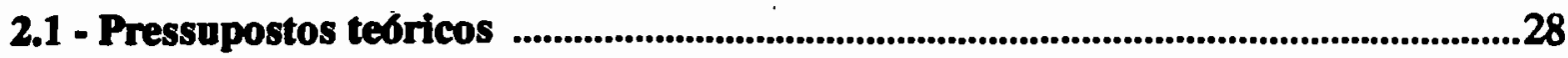

2.1.1 - Dialética e Semiótica .................................................................................................28

2.1.2 - Conceito de Ideologia .......................................................................................31

2.1.3 - O simb6lico e a assimetria epistemol6gica .....................................................32

2.1.3.1 - O simbólico e a representação ............................................................35

2.1.3.2 - A produção social do significado do medicamento ....................35

2.2 - Pressupostos metodologicos ...........................................................................................37

2.2.1 - Status do paciente hipertenso no trabalho .....................................................40

2.2.2. - Pesquisa qualitativa ..............................................................................................42

2.2.3. - O cotidiano ............................................................................................................44

2.2.4 - Entrevistas livres .....................................................................................................47

2.25 - Açāo com sentido x sentido da ação...............................................................48

2.2.6.- Vivência e subjetividade .................................................................................50

\section{CAPITULO I - O MEDICAMENTO DO PONTO DE VISTA DO SOCIAL}

I.1 - Saúde como mercadoria ...............................................................................................................51

1.1.1. - Saúde como bem de consumo ............................................................................51

1.1.2. - Saúde, mercadoria, alienação e reificação...................................................53

1.1.3 - Saúde e a tensão entre o bem e 0 mal ..............................................................54 


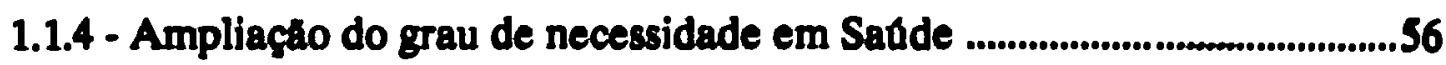

I.1.5 - Hipertrofia da dimensáo orgÂnica da Saáde ..................................................59

I.1.6 - A Saude e necessidade de Saude..................................................................................6.61

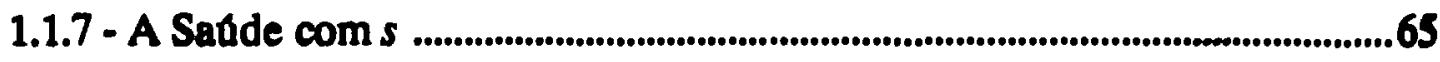

I.1.8 - Sarde como aquilo que produz saúde ...............................................................67

I.1.9 - A saúde e o ponto de vista ......................................................................................68

1.2 - Medicamento como mercadoría simb6lica .............................................................................70

I.2.1 - Medicamento como tecnologia ....................................................................70

I.2.2 - A mercadoria medicamento e os seus sentidos...............................................71

I.2.3 - Saude se "escreve" medicamento ......................................................................72

1.2.4 - Símbolo e consumo de símbolo ......................................................................75

1.2.5 - O medicamento e a saude como desejo consumido .......................................77

1.2.6- Medicamento e hóstia .............................................................................................78

I.2.7 - O medicamento como ícone quimico ........................................................79

1.2.8 - O f́cone ampliado .............................................................................................85

1.2.9.- Um interpretante do ícone: resoluçăo tecnológica da vida $x$ resoluçăo natural da vida ....................................................................................88

I.2.10 - A eficiência e a eficácia como fatos simbólicos ........................................92

I.2.11 - A ideia de eficiencia e a rapidez: ilustraçōes .............................................94

1.2.12 - O medicamento e a economia simbólica ...................................................96

I.2.13 - Eficiência simbólica e cumprimento de papéis ..........................................97

\section{CAPITULO II - RELAÇÕES SIMBÓLICAS MANTIDAS COM O MEDICAMENTO PELO PRESCRITOR MÉDICO. .}

I.1 - Introdução ......................................................................................................................105

II.2 - Relações simbolicas e relações terapeuticas ..................................................................107

II.3 - Relações simbólicas .............................................................................................................108

II.4 - Uma visão paradigmática.................................................................................................111

II.5 - Uma visão sintagmática ......................................................................................................114 
CAPITULO III- O SENTIDO DO MEDICAMENTO DO PONTO DE VISTA DO INDIVIDUO.

III.1 - Introduçáo

III.2 - Interpretaçăo e contextualizaçáo 11

III.3 - Cura e controle:eficiência e eficácia simbblica

III.4 - O medicamento, ambiguidade e moral.

III.5 - O medicamento como símbolo ambiguo e o deficiente químico .......................13

III.6 - O medicamento e a hipertensão como doença e não doença ..............................13

III.7 - O medicamento e o controle da vida $x$ controle da doença ..................................13

III.8 - O medicamento como símbolo de saúde e doença ..................................................14

III.9 - O medicamento e a necessidade .........................................................................................14

III.10 - O medicamento e a saúde como compromisso social ...........................................15.

III.11 - O medicamento e o consumo de uma alteridade negativa ................................16

III.12 - Saúde natural x saúde artificial: uma oposição simbblica...................................16

III.13 - O medicamento e a relação de comunicação..........................................................17

III.14 - O hipertenso como consumidor exemplar de medicamento ................................17

\section{IV - CONCLUSOES E RECOMENDAÇÕES}

IV.1 - Eixos temáticos .............................................................................................................18

IV.2 - Hip6teses.........................................................................................................................................182

IV.2.1 - Preâmbulo ......................................................................................................... 182

IV.2.2 - Hipóteses .........................................................................................................183

IV.3 - Conclusão geral ..........................................................................................................................190

IV.3.1 - O Sentido da Saúde e a Educação em Saúde .............................................190

IV.3.2 - Sentido global e sentido particular ...............................................................192

IV.4 - Recomendaçס̃es .................................................................................................195

\section{REFERENCIAS BIBLIOGRAFICAS}

\section{ANEXOS}




\section{RESUMO}

Na perspectiva da Saúde Pública e da Educaçăo em Saúde Pública, através de uma pesquisa de geraçăo de hipóteses, buscou-se analisar o sentido do medicamento, em nosso país, no momento presente.

Tendo como amparo térico-filos6fico geral a dialética e como amparo instrumental-analítico a semítica, considerou-se o medicamento de três pontos de vista: do ponto de vista do social, do ponto de vista do indivíduo e do ponto de vista do médico, considerados como instâncias capazes de atribuir sentido ao medicamento.

Do ponto de vista do social, considerou-se que a saúde está sujeita hoje, em nosso país, a um processo de reificação/simbolização e que o medicamento pode ser considerado, no bojo deste processo, como uma mercadoria simbolica.

Do pọto de vista dos indivíduos (representados pelos pacientes hipertensos), considerados ao mesmo tempo como objetos de um esforço social de inculcação ideológica e como sujeitos produtores autônomos de sentido, pode-se dizer que o medicamento aparece, associado a uma ampla temática correlata, como símbolo ambíguo, que remete ao mesmo tempo à Saúde e à Doença.

O ponto de vista do médico (o terceiro grande agente atribuidor de sentido ao medicamento) foi analisado sob a rubrica: relaçōes simbólicas mantidas com o medicamento pelo prescritor médico.

Como conclusão do trabalho são levantadas seis hipóteses relativas ao sentido do medicamento para os individuos. 
Seria possivel, evidentemente, levantar hipoteses sobre 0 . sentido do medicamento para o social e para o médico.

Optou-se pelo individuo considerando que, tradicionalmente, a Educaçăo em Saúde Pública é vista como prática de intervençăo sobre indivíduos e grupos, sem desconsiderar o fato de que os comportamentos destes individuos e grupos sào determinados, em última instância, a nível macrossocial.

As hip6teses dizem respeito aos seguintes temas :

- o medicamento e a oposição: natural x artificial;

- o medicamento e a relação de comunicação;

- o medicamento como símbolo ambíguo de saúde e doença;

- o medicamento e a moral: obediência e transgressāo; autonomia e heteronomia;

- o medicamento e o desejo: eficiência e eficácia simb6lica;

- o medicamento e a relação de consumo.

As hipóteses relativas a estes seis temas serão consideradas pontos de partida para trabalhos posteriores, em que se buscará verificar, em populaçōes específicas, a veracidade e a pertinência das afirmaçōes nelas contidas.

Pretende-se que o presente trabalho dê lugar à criação de uma linha de pesquisa em Educação em Saúde Pública, que tenha como núcleo a produção do sentido da Saúde na sociedade brasileira contemporânea. 


\section{SUMMARY}

This paper represents an attempt to analyse the meaning os Drug in our country, at the present moment, both from Public Health and Public Health Education perspectives by carryng out an hipothesis-generation research.

Adopting dialectics as a general theoretical-philosophical embasement and semiotics as an analytical tool, Drug is considered under three points of view: the social's,the individual's and, the physician's, all of them esteemed as instances able to assign meaning to Drug.

From the individual's point of view (represented by the hypertensive patients), seen, dialecticaly, as victims of a social effort of ideological imposition and as agents able to produce,automously, their own meanings, one can say that Drug, associated to an ample series of corelate themes, turns out as an ambiguous symbol, referred to either as Health or Illness.

The physician's point of vew (the third great agent in assigning meaning to Drug ) is analysed under the heading : "symbolic relationships concerning Drugs, heald by the prescriber physician".

Six hypothesis concerning the Drug's meaning for individuals are draw out of this work, as a conclusion. Obviously, it would also be possible to draw out hypothesis on the Drug's meaning under the social and the physician's focuses. However, the option fell on the individual, taking into acount that, traditionally, Public Health Education is seen as a discipline and as a practice wich interferes on the behavior of individual and groups (without neglecting the fact that,ultimately, the behavior of the individuals and groups is macrassocially determined). 
The hypothesis concern the following topics:

- Drug and the opposition: natural $x$ artificial;

- Drug as a message;

- Drug as an ambiguos symbol of health and illness.

- Drug and mores; compliance and transgression; autonomy and heteronomy;

- Drug and the desire: symbolic efficiency and efficacy;

- Drug and the consumption relationship.

The hypothesis concerning these six topics are considered as starting points for future works in which the purpose would be to make attemps to * check out, in target populations, the veracity and pertinency of the statements.

It is hoped that the present work provides the basis for a new research field in Public Health Education, focusing the meaning of Healht, socially produced, in the brazilian contemporaneous society. 


\section{EVOLUÇẢO?}

"It is common in Africa, for a patient whose complaints have been cured by a course of antibiotic to ask for more of the same medicine to ensure a continuing state of good health".

MICHEL,J.M. "Why people like medicines? A perspective from Africa." Lancet 1 (8422), 1985.

"Na realidade, desde há muito tempo, o brasileiro tem (ou sofre) um processso de acompanhamento quimico que vai do nascimento ao final de seus dias (...)Desenvolveu-se, desde cedo, o quimismo familiar que, em fases posteriores, passara, talvez, para os anorexigenos ou quem sabe, aos hipnóticos, antidistônicos e fortificantes. Enfim, haverá sempre uma solução química para o problema de cada um".

SA,B.A.-Drogas/seus estímulos. Jornal do Brasil 1/12/1986.

Os africanos acreditam no antibiótico; nós, no medicamento em geral. Quererá isto dizer que somos mais evoluidos que nossos irmãos africanos? 


\section{DA AUTO-MEDICAÇÃO A SAÚDE COMO MERCADORIA.}

"Eu cheguei ló, eu tou com um problema, cheguei la: "o que é que você tem? Eu olhei e: escuta aqui, nāo é médico isso af? Se eu soubé o que eu tenho eu vou na farmácia e compro o remédio que me interessa".

Dna. Eulice: Pesquisa Participante Itapecerica da Serra. Reuniāo da Pesquisa: 07/03/87.

"Há quem ache inevitável a destruição do meio ambiente no planeta. Para fazer frente às atividades destruidoras na biosfera, uma indústria japonesa produziu recipientes com cinco litros de oxigênio e um empresário abriu um "bar de oxigênio". Säo reflexos de uma filosofia de vida e da saúde que considera necessário comprar um produto para ter saúde $e$ que pode ser transformada em mercadoria o bem mais comum que tem a humanidade".

BERLINGUER, G. IN: Proposta. Radis/Fiocruz 2 (11), 1988. 


\section{NOBRES PROPOSITOS.}

"La industria farmacéutica es la única en la que és posible hacer que la explotación parezca un noble propósito"

Dr. Dale Causale: ex-director médico de la Squibb in BODENHEIMER,T.S. "La indústria farmacéutica internacional y la salud de la población mundial". Cuadernos Médico Sociales, 1983. 


\section{I-INTRODUÇAO}

\section{Definiça de problems}

Um problema estava na base deste trabalho quando ele foi originalmente concebido. Este problema dizia respeito d̀ auto-medicação.

O consumo de medicamentos sem prescrição ou orientação médica atinge, $(3,14,22,31,37,43,48,64)$, altas proporções em nosso meio e em outros países $(9,13,25,51,73)$, como por exemplo, os Estados Unidos. De . acordo com HAFFEN (38) "os americanos estão literalmente submergidos numa orgia de auto-medicaçāo" (op. cit. pag. 39).

Este comportamento representa importante problema de Saúde Pública, por este consumo implicar nos riscos diretos e indiretos, inerentes a utilizaçāo de medicamentos $(18,34,38,75)$. Estes se potencializam, naturalmente, quando aqueles são consumidos sem indicaçăo e supervisão médica. Cumpre aqui referir, também, que o consumo de medicamentos sem prescrição ou orientação médica leva a consequências não menos importantes, como a perda de poder dos antibióticos, fenômeno que está ligado à sua utilizaçāo descontrolada e generalizada pela população $(17,66,78)$. Além disto, o amplo consumo de medicamentos sem . prescrição ou orientação médica em nosso país representa problema importante de Saúde Pública por constituir fator condicionante de inibiçâo de condutas preventivas: a publicidade de certos medicamentos não afirma que o indivíduo pode comer quanto e o que quiser se recorrer a determinado remédio? Representa igualmente fonte adicional de gastos que compromete, cada vez mais, o orçamento familiar das classes médias e pobres, desviando recursos já escassos que poderiam ser aplicados em fatores potencializadores da saúde, como a alimentação (30). 
Existem fatores legais (ausencia de controle sobre as farmácias $(32,43,48)$ que deveriam exigir do cliente, a receita medica para a compra de remédios que a exigem): políticos (grupos de pressăo ligados às poderosas indástrias farmactuticas) (9) e outros, como as dificuldades de acesso aos serviços de saúde (3), que determinam, em boa medida o comportamento de consumir medicamentos sem prescrição ou orientação médica.

O problema está também ligado às deficiências na formaçāo dos profissionais de saúde bem como aos vícios de suas práticas $(69,74)$.

O comportamento de consumo de medicamentos não . orientado ou prescrito ou dirigido pelo profissional médico, aparecia então com um problema de Saúde Pública e de Educação em Saúde Pública.

No curso de desenvolvimento do trabalho fomos percebendo que poderíamos estar laborando sobre um problema real mas secundário em relação a outro problema maior. Com efeito, ao elegermos o consumo leigo de medicamentos como um problema de Educação em Saúde Pública não estávamos implicitamente, "inocentando" (também como um problema de Educação em Saúde Pública) o consumo não leigo? Não traduziria esta uma visão ingênua do problema, que conduziria a uma postura simplista frente a Educação em Saúde Pública?

Efetivamente, na medida em que consideramos a automedicação como um problema de Educação em Saúde Pública, porque ela constitui a usurpaçāo leiga de uma atribuição técnica, estamos trabalhando com os seguintes pressupostos:

a) Existe um conjunto de comportamentos em relação a saúde/doença no que tange ao medicamento; 
b) Este conjunto pode ser partido em dois sub-conjuntos:

- o sub-conjunto dos comportamentos adequados frente ao medicamento,

- o sub-conjunto dos comportamentos inadequados frente ao medicamento;

c) Quem decide o que é um comportamento adequado e inadequado é o médico ou a autoridade de saúde avalizada por este. Portanto, o problema educativo do comportamento adequado frente ao medicamento esgota-se na esfera do terapêutico, onde reina a autoridade médica.

No momento em que explicitamos, para nós mesmos, os pressupostos sobre os quais estávamos, implicitamente trabalhando, revelou-se-nos, claramente, a necessidade de uma ótica mais abrangente.

Com efeito, se atentarmos para o pressuposto $c$ que sintetiza os demais, veremos que ele é limitante exatamente porque encerra a problemática educativa ligada ao medicamento na dimensão terapêutica.

Verificamos que o consumo de medicamentos, em si, desta perspectiva, não aparece como problema. O problema aí não é o substantivo: consumo de medicamentos, mas o adjetivo: consumo exagerado, inadequado, leigo, de medicamentos.

Com efeito, as respostas habituais ao problema de Saúde Pública, consumo de medicamentos, se encaminham, de uma maneira geral, na direção de análises sobre as "disfunções" no uso dos medicamentos. 
Em grandes linhas podemos afirmar que há toda uma literatura nacional e internacional, indexada principalmente sob as rubricas: "consumo de medicamentos sem prescriçăo medica", "cumprimento das recomendaçoes médicas" e "prescriçáo abusiva de medicamentos", que é reiterativa na constataçáo superficial de alguns fatos:

a) - os individuos, vivendo em sociedades capitalistas, "selvagens" e "não selvagens", consomem, em largas proporçōes, livremente (isto ésem prescrição médica) variados tipos de medicamentos. Este consumo é mais controlado nas sociedades menos "selvagens" e menos controlado nas sociedades mais "selvagens" $(41,43,51,64)$ mas, de qualquer forma, $\epsilon$ generalizadamente considerado como abusivo.

b) - os médicos sobre-prescrevem medicamentos $(14,36$, $38,44,48)$.

c) - os pacientes, em largas proporções (57) não cumprem as recomendações médicas, em geral, e particularmente no que diz respeito ao medicamento.

Parte-se do pressuposto básico que a questão do medicamento é um problema essencialmente médico e de que existe um ato médico puro no interior do qual o problema do consumo de medicamentos deve ser enquadrado.

Com estes pressupostos em mente, concebe-se o consumo sem prescrição como um desvio ou usurpaçāo leiga da atribuição técnica ; a prescriçāo abusiva como uma extrapolaçāo profissional, freqüentemente feita pelo médico como resposta a uma pressão do paciente (14) e o não cumprimento da prescriçāo como uma questão de rebeldia ou falta de fé do paciente no médico ou . como uma questão técnica do médico "vender bem o seu peixe" para o paciente(49). 
Concebidas assim estas questoes, propoe-estratégias educativas, junto ao médico e demais profissionais de saúde e junto ao paciente, bem como intervençoes no plano administrativo dos serviços de saúde e no plano legal, todas elas visando reduzir as proporçóes do fenomeno.

Assim, no curso das reflexסes sobre o assunto foi-se-nos impondo gradativamente a idéia de que a relação (do consumidor, mas também do prescritor) com o medicamento implica, do ponto de vista da Educação em Saúde Pública, em mais coisas do que auto-medicação, ou cumprimento, ou descumprimento das recomendações médicas, porque o sentido do medicamento não se esgota na dimensão terapêutica.

Mais precisamente, ao abordarmos ingenuamente o problema da auto medicação, podemos estar pressupondo que o sentido do medicamento se confunde com sua funçāo terapêutica. Ora, segundo cremos, o medicamento é mais do que um agente quimioterápico.

Assim, as limitações percebidas num estudo sobre a automedicação nos levaram a idéia de que era necessário ir mais a fundo na investigação do sentido do medicamento.

Como deve, pensamos, fazer parte das atribuiçōes da Educação em Saúde - interessada que está em interferir eficazmente nos comportamentos dos indivíduos e grupos com vistas a, segundo ALLEGRANTE in CLEARY (19) " promover, manter e incrementar a saúde individual e da comunidade" (pag.67), entender as várias dimensões associadas ao ato de consumir e prescrever medicamentos, pareceu-nos que seria pertinente o encaminhamento da investigação para além do espaço terapêutico. 
A partir dal foi se delineando o proposito de investigar o sentido do que está por trás do ato de consumir, da forma que seja, um medicamento (o que leva, automaticamente, a investigar tambem o sentido subjacente ao ato de prescrever um medicamento). Nessa linha colocam-se questóes como: o que significa consumir um medicamento? Qual o sentido deste objeto de consumo?

A busca deste sentido nos conduziu para o espaço social mais amplo das formaçð̄es sociais capitalistas, onde pontifica a Mercadoria e o Símbolo em relações de estreita interdependência.

Na tentativa de entender o porquê (e não apenas o como) o consumo de medicamentos constitui, hoje, um problema de Saúde Pública em nosso país (e alhures), é preciso ir mais fundo, ultrapassar o nível descritivo de análise do social.

Ao ir mais fundo nos defrontamos, inevitavelmente, com questões mais primárias, relativas à própria natureza do medicamento, do seu consumo e do consumo em geral de mercadorias.

A decisão de ir mais além da mera descrição do fenômeno, prende-se ao fato de que, colocada a questão no nível em que ela é habitualmente colocada, permanece-se na superficie enganosa do tecido social: o consumo de medicamentos aparece como problema para a Saúde Pública apenas na medida em que é visto como uma disfunção (o consumo sem prescrição, o consumo abusivo, etc.), um desvio de rota a perturbar o equilifrio, dando ensejo ao nascimento de estratégias destinadas à retomada do equilíbrio. 
Ora, a perspectiva teorica adotada neste trabalho permite amparar e desenvolver a crença de que o consumo de medicamentos (de um modo geral e nåo apenas o consumo sem prescriçăo, exagerado, etc.) no Brasil, boje, é um problema de saúde pública náo enquanto disfunçăo social mas ao contrário por ser uma funçāo, ou expressăo social da hegemonia da mercadoria.

Assim, em conformidade com o referencial teorico adotado, este estudo sobre a entidade "medicamento" procurará enfocar, ou como se diz modernamente, "construir" o objeto não como um fato positivo ("O método dialético, portanto, é oposto em seu projeto a todo método de tipo positivista") (BRUYNE (12), pag 74), mas como um campo tensional onde coexistem diferentes tipos e funçōes do medicamento.

Nesse sentido, partimos do pressuposto que o objeto medicamento, na formaçāo social brasileira, nảo é uma mas, pelo menos, três coisas: um agente quimioterápico, uma mercadoria e um símbolo.

E nāo se trata aqui, simplesmente, nem principalmente, de descrevê-lo de forma justaposta, enquanto agente quimioterápico, enquanto mercadoria e enquanto símbolo; ou da perspectiva da biologia/farmacologia/medicina, da perspectiva da sociologia e da psicossociologia e da perspectiva da semiologia.

Cremos que na formaçāo social concreta do Brasil atual, o entendimento da problemática de Saúde Pública ligada ao medicamento ganharia muito, a nosso ver, se esse fosse visto nāo corno uma destas três coisas mas como as três coisas ao mesmo tempo ("A ambiguidade dialética insiste na ambivalência de certos fenômenos que são, ao mesmo tempo, de natureza $A$ e de natureza não-A (...) 
as situaçơes vividas concretas såo freqüentemente desta natureza") (BRUYNE (12), pag. 70).

Portanto, não se nega - o que seria um absurdo - que o medicamento cura, controla e previne (dimensão quimioterápica/médica); não se afirma simplesmente que aliena e domina (dimensão social e psicossocial) e que representa e simboliza (dimensão semiotica e simbólica).

O que se nega é que ele perfaça, essencialmente, uma destas três funçōes. "O marxismo estabelece em princípio o reconhecimento do dado da estrutura complexa de todo objeto concreto... Não temos mais uma unidade simples, mas uma unidade complexa estruturada" ((ALTHUSSER in: BRUYNE (12), pag. 67).

E pois dentro desta perspectiva mais ampla que buscaremos entender o objeto medicamento, localizando-o em regiōes mais críticas do tecido social das formações sociais capitalistas como a brasileira, o que implica em entendê-lo como uma mercadoria, que traduz um processo de reificaçāo da saúde; como um agente quimioterápico, que funciona aliviando, curando e controlando . processos mórbidos a nível do organismo e como símbolo, que permite que a Saúde (ou mais precisamente, a Saúde" biologizada") esteja representada no medicamento.

Evidentemente, estas três dimensōes do medicamento ligam-se entre si de modo que ao mesmo tempo que é necessário analisá-las isoladamente é igualmente preciso analisá-las em conjunto, na busca da articulaçāo entre a mercadoria reificada, o agente quimioterápico e o símbolo. 
Dito isto, nos debruçamos sobre a tarefa de buscar nos novos pressupostos a sustentação do que acreditamos ser um enfoque mais pertinente, do ponto de vista da Educação em Saúde Pública, em relaçăo ao problema do medicamento, qual seja: a descriçáo dos processos ligados à simbolizaçáo dos agentes quimioterápicos associado à sua caracterização como mercadoria, o que configura um processo de consumo de símbolos (5) de saúde.

O trato destas questōes, sob o enfoque da Educação em Saúde Pública, é o desafio que nos propomos a enfrentar.

\section{2 - . O problema no contexto das visões de Saúde.}

Toda tese sobre Saúde Pública tem uma visão implícita ou explícita de Saúde. Este trabalho adota uma visão ampla de Saúde, que permite indicar, por contraste, o que cremos ser o caráter restritivo das visões hegemômicas* de Saúde, vigentes, na prática, nas formações sociais capitalistas e em nosso país.

Esta distinção entre a visão ampla e a visão restrita encontra-se, em outros termos, na oposição estabelecida por LUZ (48), entre "Saúde e saúde". A autora contrapõe: "Saúde como sinônimo de medicalização e que remete às Instituições Médicas e a saúde que remeteria, nas formações sociais capitalistas, diretamente às condiçōes globais de vida (alimentação, habitação, repouso, educaçāo e participação decisórias nos vários níveis da vida social).... portanto às condições em que se dá a produção social" (pag. 61, 62).

" Segundo LUZ (48) de acordo com GRAMSCI, hegemonia é o: "poder político-ideológico que a classe dominante procura estender ao conjunto da sociedade, à totalidade das classes e grupos sociais". (pag. 29). 
A Saúde aparece, hegemonicamente, na prática, como uma mercadoria. Ou melhor, ela toma a forma, no modo de produçáo capitalista e em nosso país, de mercadorias propiciadoras de saúde: Golden Cross é saúde, Hepatovis é a saúde de seu fígado, a consulta médica é saúde.

É o que afirma LUZ (48) a propósito do papel do Estado na área da Saúde, em nosso país: "quais as propostas, em termos políticos, de saúde do Estado? Responderá de acordo com os interesses sociais que o constituem. E entre esses interesses salientam-se os das indústrias farmacêuticas e de equipamentos médicos..."

"Desta maneira, incentivam-se as consultas ambulatoriais médicas, por um lado e o consumo de medicamentos por outro" (pag. 19).

Mas ao lado, ou em decorrência do seu caráter de mercadoria, a saúde aparece como coisa: é o processo de reificação da saúde. Ela toma a forma hegemônica de uma coisa concreta deixando eclipsada a sua dimensāo de relação (com o social, com o comportamental).

A Saúde, então, estreita-se, afunila-se,reduz-se, enfim, transforma-se de Condição Humana Prévia, Preliminar, em Mercadoria (o medicamento é uma delas). A Saúde é, assim, expropriada - e esta expropriaçāo é um lento processo histórico - da sua condição de Premissa Existencial para ser (apenas) recuperada e recuperável num mercado de bens de consumo.

Este processo histórico transforma a Saúde numa necessidade jamais satisfeita, não apenas porque - como a fome - deve ser re-satisfeita cotidianamente mas também porque, no processo mesmo de expropriação, a Saúde 
perde - no sentido moral da palavra - o seu Unico sentido posstvel (o de Premissa Existencial) passando a admitir Todos os sentidos posstveis .

Em decorrência disto, nas sociedades de consumo modernas é possível realizar-se plenamente - a farsa virou tragédia - o propósito daquele médico de ficção que afirmava que o "sadio é um doente que se ignora".

Com efeito, nestas sociedades, a ninguém é permitido sentir-se verdadeiramente saudável porque estará, sempre, "faltando algo" (no plano orgânico, mental,estético, comportamental, etc.); haverá, sempre, uma sensação de vazio, a ser preenchido por algum serviço ou mercadoria.

A Saúde foi então, historicamente, adaptando-se à lógica do mercado* e hoje em dia é possível afirmar-se,e reunir elementos empíricos que tornem plausível esta hipótese,que ela se expressa ou é representada (no "palco" social) através de serviços ou mercadorias; ou seja, de que a Saúde acabou tornandose algo que obtém-se ou re-obtém-se permanente e infinitamente, pelo consumo de substâncias (medicamentos, yogurtes,etc.) ou ações (ginásticas,massagens,etc.), investidas de Saúde. A Saúde deixa de ser uma característica de todo ser biologicamente bem formado,vivendo numa sociedade "bem formada", e passa a ser algo a ser obtido pelo consumo ; semioticamente, ela passa a estar na mercadoria "saudável".

Esta mercadoria/Saúde porisso mesmo, é um signo. Afirma BAUDRILLARD (5) a respeito.

\footnotetext{
"E o processo que aparece, no pensamento sanitário, sob a rubrica de "medicalizaçāo" da sociedade mas que $e$, em geral, mal comprendido porque está vinculado à noção funcionalista de "disfunção social" ou "desvio" (a ser corrigido por bem intencionados sanitaristas) e não aos mecanismos estruturais, ligados à ampliação e generalização do "mercado"
} 
"Nos atingimos aqui a lógica formal da mercadoria analisada por MARX: da mesma forma que as necessidades, os sentimentos, a cultura, o saber, todas as forças próprias do homem estão integradas como mercadorias na ordem da produção, se materializam em forças produtivas a serem vendidas. Hoje todos os desejos, os projetos, as exigências, todas as paixōes e todas as relaçoes se abstraem (ou se materializam) em signos e em objetos para serem comprados e consumidos" (pag. 234) (grifos nossos).

Nesse sentido, a mercadoria, o medicamento aparece, nestas formaçōes sociais capitalistas, como uma das materializaçōes ou símbolos de saúde. Como afirma CORDEIRO (23)* "o medicamento ocupa o lugar de símbolos e representaçōes que invadem os determinantes sociais das doenças, iludindo os indivíduos com a aparência de eficácia científica e como mercadorias, realizam o valor e garantem a acumulação de um dos segmentos mais lucrativos do capital industrial" (pag. 57).

Sem avançar, por hora, no detalhamento desta dimensāo simb6́lica do medicamento, diremos apenas que o símbolo é, entre outras coisas, um artifício que permite tornar concretas entidades abstratas ou vagas, como é o caso da saúde.

Daí a estreita associação entre os fenômenos de reificaçāo e simbolizaçāo.

* A afirmação do autor se refere não a todo medicamento mas a um certo uso deste. 
Com efeito, enquanto símbolo, medicamento concentra" saúde e enquanto mercadoria ele oferece esta concentraçăo como bemadquirível no mercade.

A saúde pode também ser vista, na nossa cultura e na nossa sociedade, como um valor transcendente.

Em função disso, o fato dela aparecer, nesta sociedade e nesta cultura, como decorrência do modo de produção capitalista, sob a forma de representações concretas, que são as mercadorias de saúde, confere a estas representaçōes mercadológicas força simbólica (valor, desejo reificado).

O medicamento enquanto símbolo de saúde - inclusive na medida em que o usuário leigo não tem idéia de como ele funciona no organismo é a possibilidade mágica, que a ciência, através da tecnologia, tornou * acessível, de materializar,representar, numa pílula ou em algumas gotas, este valor/desejo, sob a forma de prevenção, remissāo, triunfo definitivo (na cura) e reproduzido no dia a dia (no controle), sobre o cortejo de males do corpo e da alma que afetam o homem, e sobre as "carências" ou "limitaçōes" inerentes a condição humana: medicamentos geriátricos contra a perda da memória, vitaminas contra a calvice, etc...

E interessante, a este respeito, lembrar que no slogan de uma das campanhas anti-p6lio em nosso país havia a mensagem: "a gota que salva" onde algo tão pequeno como uma gota (que na nossa lingua é componente de metáforas relacionadas à noção de "pequeno" como: "uma gota d'agua no oceano")

\footnotetext{
* O processo de simbolização, implica em concentrar, comprimir, por exemplo, o amplo cristianismo na forma concreta da cruz de Cristo(76).

* * ...ou tornará, já que faz parte da crença generalizada em nossa cultura o fato de que a ciência $\epsilon$, a longo prazo, onipotente.
} 
concentra em si ou simboliza a Saúde como a grande_salvaçăo da tragédia que significa uma criança presa a uma cadeira de rodas.

Este exemplo sugere que o medicamento e o símbolo podem se identificar através da relação pequeno-grande onde o pequeno concentra em si ou representa o grande, como por exemplo, as pequenas estrelas da bandeira brasileira que representam os vastíssimos territórios ou estados do país.

Estāo, portanto, em jogo aqui duas visōes radicalmente distintas de saúde: a visāo ampla e abrangente de um lado e a visão mercadológica, reificada e simbólica da saúde de outro.

Esta última tem como uma de suas mensagens possíveis: "a Saúde como valor concentrado ou representado, ou simbolizado num comprimido encontra-se à venda nas farmácias".

E precisamente na medida em que o medicamento aparece com este sentido que ele nos interessa como problema, no campo da Saúde Pública e da Educação em Saúde Pública.

\section{3 - O problema e a sua pertinência para a Educação em Saúde Pública.}

A Educação em Saúde Pública se caracteriza por ser uma intervenção sobre pessoas e grupos com vistas a que estas pessoas ou grupos adotem práticas conduncentes à Saúde. 
Ora, a adoçăo destas práticas pelos individuos ou grupos, sobretudo quando se trata de populaçőes adultas, supóe um trabalho educativo que nåo se dá no vazio. Este trabalho precisa considerar os sentidos pré-existentes nos atores do processo educativo e na propria sociedade onde estes atores atuam.

Estes sentidos préexistentes podem ser traduzidos na linguagem da Educação em Saúde Pública como fazendo parte dos "fatores predisponentes"(35) em relação à adoção destas práticas.

Com efeito, uma prática, para a Educação em Saúde não é comportamento instintivo ou automático, mas a tradução, na ação, de um determinado sentido que o indivíduo ou grupo imprime, consciente e voluntariamente $(19,35)$, à ação.

Podemos então afirmar que o sentido das práticas propostas pela Educação em Saúde, para ser adotado pelos indivíduos ou grupos e traduzido em comportamentos, precisa ser visto como competindo com uma constelação de sentido préexistentes.

Parece-nos portanto, que na análise dos fatores prédisponentes do processo educativo da Educação em Saúde deve estar sempre incluída uma etapa na qual se possa dar conta - em alguma medida - dos sentidos préexistentes de que falamos acima.

O consumo de medicamentos considerado sob o ângulo da Saúde Pública e da Educação em Saúde Pública é um comportamento repleto de sentidos préexistentes ou de fatores predisponentes ligados ao sentido. 
Assim, a intervençåo da Educaçáo em Saúde frente ao comportamento de consumo de medicamentos pressupóe a análise e deteç̧ăo destes fatores predisponentes.

O presente trabalho $\varepsilon$ uma tentativa de abordagem do assunto onde se busca resgatar estes fatores a nível da sociedade como um todo, representada pelas camadas socialmente hegemónicas,a nível intermediário, representado pelo prescritor médico (de fato, o médico pode ser visto ,hoje $(14,32,44)$, como estando imprensado entre as camadas hegemônicas e os pacientes) e a nível terminal, representado por um grupo de pacientes crônicos hipertensos atendidos pela rede básica de saúde. 


\section{II · PRESSUPOSTOS TEÓRICO- METODOLÓGICOS}

\section{1 - Pressupostos téricos}

\subsection{1.- Dialética e Semiótica}

No presente trabalho, o referencial teórico a ser adotado será constituído pelo que BRUYNE (12) chama de perspectiva ontológica, filosofica geral e metodológica da dialética.

A perspectiva ontológica dá conta do "movimento concreto, natural e sócio histórico, da própria realidade estudada" (BRUYNE (12), pag. 65).

A perspectiva filosófica geral diz respeito à "lógica do pensamento que se pretende conhecimento adequado dos processos históricos, das mudanças e dos conflitos sociais" (BRUYNE (12), pag. 65).

Metodologicamente a perspectiva dialética é entendida aqui como "a tentativa de conhecer a cada momento a análise como uma parte do processo social analisado e como sua consciência crítica possível. Isso implica que se renuncie a supor entre os instrumentos analíticos e os dados analisados (uma) relação externa puramente contingente" (HABERMAS, in: BRUYNE (12), pag. 65).

Evidentemente, quando se coloca a perspectiva dialética como eixo teórico do trabalho se a está pensando, de um ângulo metodológico, como Teoria da Contradições, tal como a enuncia ALTHUSSER (2), no contexto da tradição filosófica hegeliana e marxista. 
Se a dialética como Teoria das Contradiçoes permite neste trabalho, como afirma BRUYNE (12), dar conta do "movimento concreto, natural e socio-histórico da própria realidade estudada", ela está sendo, ipso facto, responsável pela dinâmica ou pela dimensão diacrônica do sentido do medicamento .Esta dimensão expressa-se mais diretamente aqui através da noção de ponto de vista. "Ponto de vista" deve ser entendido, portanto, no sentido literal da palavra. Não se confunde, assim, com "opinião". Trata-se de um ponto no espaço (social, econômico, profissonal e psicossosical), a partir de onde se vê o mundo e que condiciona, determina, limita, o que se pode ver e como se pode ver.

São três os pontos de vista a partir dos quais se entende o sentido do medicamento: o ponto de vista da sociedade (que é responsável pelo sentido do medicamento como Mercadoria (V.1.1.9), o ponto de vista do médico e o ponto de vista do indivíduo.

As relaçōes entre estes três pontos de vista sāo complexas, havendo conflitos,relações de hegemonia, de rebeldia, de aceitação passiva,etc.

São estes conflitos que, da perspectiva dialética, permitem entender o "objeto" medicamento e o seu sentido numa perspectiva histórica, diacrônica; o que, por sua vez, permite avançar alguns passos na comprensāo da Saúde (que é o campo social e institucional onde o medicamento se situa, modernamente) como "objeto histórico". Em outras palavras, a dialética dos "pontos de vista" (em conflito) sobre o medicamento permite vislumbrar algumas virtualidades da evolução histórica do conceito de Saúde e, por extensão, de Vida, a partir das sociedades industriais modernas. 
Algumas categorias básicas presentes na análise sociológica, fundada na perspectiva dialética das formaçőes capitalistas, serăo especialmente destacadas. Dentre elas o conceito de reificacăo e alienaçáo $(33,39,79)$, de ideologia $(79)$.

Associada à perspectiva dialética, o trabalho está apoiado . na Semiótica e na Semiologia, tal qual a concebem, na tradição anglo-saxã (PIERCE $(58,59)$, e na tradição europeia de origem latina (TODOROV $(76)$ e ECO $(28,29)$, e na mesma Semiótica e Semiologia aplicada à análise das sociedades industriais capitalistas tal como o fazem (BARTHERS (4), (BAUDRILLARD, $(5,6)$ e (VERON (79).

A Semiótica, então - na qualidade de Ciência Geral dos processos de significação - é responsável pela dimensão sincrônica do trabalho, no sentido de que ela permite aprofundar, verticalmente, a mecânica dos processos necessariamente plurais (e conflituosos) - de produção do sentido da Saúde, e, mais especificamente, a mecânica do funcionamento do medicamento como símbolo de . Saúde, nas sociedades industriais contemporâneas.

Vale clarificar a utilizaçāo, neste trabalho, dos termos : significante/significado e sentido, e as construçōes nas quais estes termos figuram.

Quando se usa o par significante/significado (evidentemente, numa ótica saussuriana) o que se está procurando indicar é a relação entre uma dada realidade concreta (que é o significante, a parte material do signo) e a idéia (o significado, a parte cognitiva do signo) que este significante expressa ou veicula, através das regras (códigos) inerentes ao processo de simbolização. 
Sentido, por seu turno, é usado seja como sinónimo de interpretaçáo,explicação, definiçáo (e que, conceitualmente, em PIERCE (59), equivale d noçăo de interpretante )seja, na expressåo "produçåo de sentido", tal como a entende VERON (79) enquanto ação social ou semiose social, através da qual é produzida, pela sociedade e na sociedade, por cada um de seus grupos, classes, estratos, segmentos, corporaçōes, categorias de indivíduos, o sentido, ou ideologia ou "razão de ser" das coisas

\subsection{2 - Q Conceito de Ideologia}

E preciso aclarar agora um conceito central que está presente, no trabalho. Trata-se do conceito de ideologia ou de domínio do ideológico.

A nossa visāo sobre este controverso conceito implica em considerá-lo como algo muito mais embebido no tecido social do que a tradição marxista mais clássica costuma habitualmente reconhecer.

Assim sendo, adotamos como referencial o ponto de vista de VERON (79) um dos teóricos que, do nosso ponto de vista, reflete melhor o pensamento contemporâneo sobre a questāo. Afirma o autor a respeito do caráter de ubiquidade do ideológico: "O ideológico e o poder são, portanto, dimensōes que atravessam, em toda sua extensão, uma sociedade.

"Trata-se de compreender a Semiose necessariamente investida em toda forma de organização social (...). Sem essa semiose nenhuma forma de organização social é concebível" (pag. 194). Mais adiante, definindo o ideológico no contexto social, afirma o mesmo autor: "O ideológico é o nome do sistema de relaçōes entre um conjunto significante dado e as suas condições sociais de produção". 
"Nas sociedades industriais capitalistas, essas condiçőes concernem (se bem que náo exclusivamente) a maneira porque a rede de semiose social e dinamizada pelos conflitos de classes" (pag. 196)".

Coloca o autor portanto, com a cautela necessária, o também controverso problema das relaçōes entre o ideológico e o social, numa sociedade de classes quando, não negando as relações entre o ideológico e o conflito de classes, as matiza. Mais adiante, reafirmando a mesma idéia, coloca o autor: "O domínio ideológico e (...) vasto. Diz respeito a todo o sentido produzido onde as condições sociais de sua produção deixam traços (pag. 199)".

Finalmente busca descaracterizar a ideologia como fenômeno meramente superestrutural. Para ele, com efeito: "não existe superestrutura ideológica porque sem ideologia, isto é, produção social de sentido, nãa haveria nem mercadoria, nem capital, nem mais valia". (pag. 199) (grifos nossos). E pois no espírito deste refencial que será usado o conceito de "ideologia", neste trabalho.

\subsection{3 - $\underline{\text { O Simbólico e a Assimetria Epistemológica }}$}

Como este trabalho lida com o simbólico e como "simbólico" é um termo que aparece com frequência na literatura sobre saúde/doença com um significado que não adotamos e que, cremos, traz consigo implicações epistemológicas, é necessário, desde o início, deixar claras nossas posições.

Com efeito o adjetivo "simbólico" aparece, em português, com muita frequência, como implicando um campo de significados ligados às oposiçōes semânticas: 


$$
\begin{aligned}
& \text { - imaginário/real } \\
& \text { - subjetivo/objetivo } \\
& \text { - crença mística/evidência fatual } \\
& \text { - magia/ciência } \\
& \text { - ficção/realidade }
\end{aligned}
$$

Por exemplo, na frase: "Foi cobrada uma taxa simbólica para o ingresso na associaçāo", "simb6́lico" se opõe à "real". Em seu artigo: "A ação transcendente dos medicamentos", MORAES FILHO \& BOMBONATTI (54) afirmam: "Na realidade, à ação objetiva da prescrição sempre se soma outra, subjetivą, exercida pela figura do médico. Há um valor simbólice no ato médico que se inicia antes mesmo que a intervenção farmacológica propriamente dita venha a ocorrer" (pag. 264) (trechos sublinhados, em itálicos no original).

Nestas afirmaçōes está fortemente sugerida uma assimetria de status epistemológico entre o que pertence ao domínio simb6́lico e o que não pertence.

A diferença de status epistemologico referida diz respeito ao fato de que não se considera o campo do simbólico, em si,como objeto de conhecimento. Ele aparce como um campo do não cognocível, ou do ainda não conhecido e/ou do ainda não tecnologicamente controlado.

Esta assimetria presente no domínio do simb6lico, quando relacionada à temática da saúde/doença/medicina, dá margem, tradicionalmente, a análises que enfatizam aspectos mágicos presentes (sobreviventes) nas práticas "leigas" e "profissionais" da medicina; a aspectos subjetivos relacionados a efeitos de medicamentos (efeito placebo), sem falar no campo, sem fronteiras claras, da medicina psicossomática. 
A este respeito vale a pena uma análise um pouco mais detalhada do artigo citado de MORAES FILHO e BOMBONATTI porque ele nos parece muito ilustrativo desta visão do simbólico quando relacionada à área da "saúde". Afirmam os autores: "Há um yalor simbólice no ato médico que se inicia antes mesmo que a intervenção farmacológica propriamente dita venha a ocorrer. Impossivel definir (grifos nossos) o que realmente vem a ser esta força imponderável (grifos nossos) que exerce a figura do médico. E possível (grifos nossos) que a postura, o olhar, a voz, o toque durante o exame físico, a segurança no escrever a receita, tenham importância. E possível até que outras forças e nível anímico (grifos nossos) estejam entre os dois seres ali presentes - médico e paciente. Mas não importa definir de onde vem a força do médico (grifos nossos): esse invisível elo com o chamā, com o curandeiro, com o pajé, com o santo milagreiro, é a mágica (grifos nossos) que envolve a relação com o paciente. Observa-se que o comportamente místico (grifos nossos) do médico em face da doença pouco muda ao longo dos séculos" (pag. 265).

Fica perfeitamente claro por esse exemplo a assimetria de status epistemológico entre o simbólico e o que está fora dele: o simbólico, para a corrente de pensamento, ou ideologia, ou visāo de mundo que estes autores adotam implicitamente, é o domínio das "impossibilidades definitórias", das "forças imponderáveis", do "E possível", do "invisível elo com o chamā..." Esta ideologia proclama pois, que existe algo, além do fato positivo (o simbólico) e que este algo $\varepsilon$. fator interferente no campo da "saúde". Só que, para ela, este algo não merece o status de objeto de conhecimento: são coisas "impossíveis de definir" ou coisas "que não importa definir de onde vem", ou coisas "invisíveis". 


\subsubsection{1 - Q Simbolico e a Representacão}

E importante colocar que, neste trabalho, que diz respeito ao simbólico na área da "saúde", năo se compartilha desta visão do mundo.

Neste trabalho, o domínio do simbolico, objeto legítimo de conhecimento, está referido, nuclearmente, à idéia de representação, no sentido pierceano do termo (v. 1.2.5.).

E claro, por outro lado, que a temática exemplificada nesta citação é real, pertencendo, de jure e de fato, ao campo da saúde. Vinculada à idéia de representação (ela mesma ligada ao campo da semiótica da sociologia e da antropologia) o domínio do simbólico na área da saúde abarca, entre outras, as temáticas do efeito placebo dos medicamentos, do caráter ritual dos atos médicos ligados ao medicamento, do poder médico, etc...

Cabe portanto descrever estas e outras realidades conexas como envolvendo processos de representaçào ou, como coloca VERON (79) de produção social do significado.

\subsubsection{2 - A Produção Social do Significado do medicamento.}

A idéia de "produção social do significado" tomada do texto de VERON (79) merece algumas consideraçōes adicionais para que fique mais clara.

A primeira coisa a esclarecer é que colocar o nosso tema, o medicamento, como objeto de um processo social de produção do significado já permite identificar uma postura determinada frente ao objeto medicamento: a de que 
ele possui significados outros que os seus significados "espontaneos", e que estes significados såo gerados numa dada formaçào social concreta.

Parte-se pois do pressuposto de que o significado do medicamento não é um já-dado, "natural", a-histórico mas um produto, secretado por um dado sistema social e numa dada formaçāo social concreta.

O sistema social e a formação social são, pois, vistas, . desta perspectiva, como "máquinas" de produção de significados.

Como a "máquina social" produz significados? Imaginemos um exemplo: muitas farmácias "modernas", em nosso país, estão atualmente montadas de modo semelhante a supermercados: o consumidor compra seu remédio no balcão, vai com a sua mercadoria até um dos caixas, deposita o remédio na esteira e sai, após pagar, pelo corredor do caixa. Outras farmácias estāo montadas sob a forma de "Drug Store" onde, alem de medicamentos, pode-se comprar brinquedos, batatas, material de limpeza doméstica, etc...

Com este modo de comercializar o medicamento está se passando, implicitamente, o significado que o medicamento é um produto equivalente a qualquer outro produto de supermercado, o que implica, entre outras coisa, no significado adicional de que a doença é algo tão "natural", "banal", "corrente" como a fome, a gordura das panela, a necessidade infantil de jogo, etc...

Admite-se pois que a "máquina social" produz significados secretados diretamente de seu funcionamento, além daqueles significados produzidos através de discursos explícitos, como as bulas e as peças publicitárias de medicamentos. 
Nesse sentido, é que a semiótica $(4,5,6,28,29)$ postula que das açóes sociais, dos arranjos espaciais, das mercadorias, etc... emanam mensagens ou seja produtos simbólicos e que, portanto, as açōes sociais, os arranjos · espaciais, as mercadorias, podem ser considerados símbolos através dos quais se escrevem discursos, por exemplo, sobre a saúde e a doença.

Assim, o domínio do simbblico no campo institucional da saúde envolve não o imponderável ou o místico mas a produção e a atribuição de significado ao médico, cura, medicamento, etc..., numa e para uma determinada formaçào social concreta.

Neste trabalho, busca-se especificamente, responder a

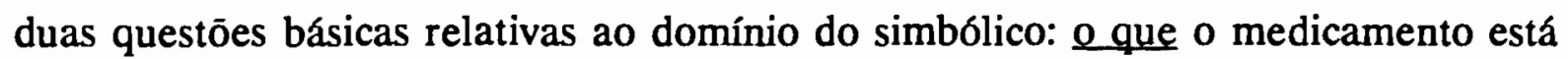
representando, simbolizando num determinado contexto sócio-histórico e como o medicamento funciona no interior deste processo sócio-histórico de representaçāo, ou simbolização.

\section{$\underline{2.2}$ - Pressupostos metodologicos.}

Trata-se de um trabalho que se situa totalmente num contexto de lógica de descoberta, de geração de hipóteses, por oposição a um contexto de lógica de demonstração de hipóteses.

Busca-se entender $o$ sentido de um objeto - $0^{\circ}$ medicamento - desenvolvendo-se no curso do trabalho, um grande pressuposto inicial de que o sentido deste objeto vai mais além do que a sua mera existência fenomênica 
Procurar-se-á explorar o sentido do medicamento (ou melhor, a própria idéa de que o medicamento tem um sentido, alem do seu sentido obvio) a partir de dois sujeitos atribuidores do sentido: um sujeito impessoal, situado no seio das forças sociais hegemônicas, responsáveis pelo destino do medicamento como mercadoria, ou seja, pelo seu sentido como mercadoria e alguns sujeitos individuais, que pela sua condição de pacientes crônicos hipertensos, que tem que conviver, no cotidiano, com o medicamento, aparecem como atribuidores privilegiados de sentido ao medicamento.

Há, no entanto, no que se refere ao medicamento, um outro grande sujeito atribuidor de sentido, que é o médico.

Com efeito, o medicamento pode ser visto como um instrumento de trabalho do médico, o que é, por si s6, uma razão suficiente para conferir a este ator social um lugar privilegiado na classe dos sujeitos atribuidores de sentido ao medicamento.

No entanto, como este trabalho se propōe a discutir a dimensão simbólica do medicamento, o sujeito médico, para o qual esta dimensão é fortemente recalcada, em favor da dimensão terapêutica, torna-se um sujeito discrepante, se pareado com os outros dois sujeitos: o social e o individual.

Não que o médico nāo participe, ativamente, da dimensão simbólica do medicamento e da sua "implementação" (ou, como prefere o marxismo ortodoxo, "inculcação ideológica"). 
Ocorre que, pelo fato da dimensåo terapêutica ser, formalmente, a dimensáo "legitima" do sentido do medicamento, do ponto de vista do médico, o desenvolvimento de uma pesquisa empírica com este profissional implicaria necessariamente a análise de um poderoso conflito interno - ao campo médico - entre o medicamento como mercadoria, como agente quimioterápico e como símbolo.

Ora, esta análise, em função da densidade da temática, implicaria algo como uma pesquisa, da dimensão do trabalho como um todo, dentro da pesquisa, o que, obviamente, quebraria a harmonia do trabalho.

Consideramos então, nesse trabalho, apenas um aspecto da ampla problemática atinente ao medico como atribuidor de sentido ao medicamento.

Em função deste enfoque voluntariamente parcial do problema,seria totalmente inapropriado individualizar um capítulo - com este conteúdo - que teria por título : " o sentido do medicamento do ponto de vista do médico".

Sendo assim, neste trabalho, o ponto de vista do médico sobre o medicamento aparece individualizado num pequeno capítulo que tem por título: "Relaçōes simbólicas mantidas com o medicamento pelo prescritor médico".

Há portanto uma clara assimetria no trabalho: o ponto de vista do social e o ponto de vista do indivíduo aparecem com muito mais destaque que o ponto de vista do médico, do qual tem-se uma visāo apenas parcial. 
Cremos contudo que esta assimetria ocorreria de qualquer modo, por hipertrofla ou por hlpotrofia do ponto de vista do médico.

Como a análise, acima referida, dos conflitos de sentido no interior do campo médico (que implicaria numa opçăo pela hipertrofia) nåo é o foco de nosso trabalho, só nos resta a opção pela hipotrofia.

\subsection{1 - Status do paciente hipertenso no trabalhe.}

Fica claro, portanto, que o objeto deste trabalho é o medicamento (visto sob um certo ângulo) aparecendo portanto o paciente hipertenso - em funçāo de algumas peculiaridades deste paciente (Ver 2.2.2) - como uma das fontes possíveis de obtenção de dados sobre o sentido do medicamento do ponto de vista dos indivíduos.

Portanto, o medicamento, objeto deste trabalho, é visto aqui sob dois pontos de vista (o do social e o do indivíduo) e marginalmente, do ponto * de vista do médico.

Usando a ideia de Conjunto como imagem, teríamos um conjunto maior - o medicamento - no qual estāo incluidos tres sub conjuntos (o ponto de vista do social, do indivíduo e do médico). O paciente hipertenso representa, portanto, um sub conjunto (de "segundo grau"),do sub conjunto (de "primeiro grau"): "ponto de vista dos indivíduos sobre o medicamento".

Assim colocado o problema fica, cremos, atestado o status do paciente hipertenso neste trabalho. 
Nem poderia deixar de ser de outro modo: em se tratando de uma investigaçăo inicial, exploratória, de geraçáo de hipóteses, nåo cabem, logicamente, controles maiores na escolha do "adjetivo" (os pacientes hipertensos) já que o foco da atençăo e o "substantivo" (o sentido do medicamento).

Com efeito, o que se busca, basicamente, $c$ investigar o sentido do medicamento nas formaçōes sociais capitalistas, dentre as quais a brasileira.

Nesse contexto de preocupações, parece-nos necessário, primeiramente, firmar este ângulo de abordagem do campo da saúde pública e da Educação em Saúde Pública. Ora, isto exige um investimento inicial que deve se concentrar na tentativa de apresentaçāo, elucidação, deste ângulo de visão, antes de se partir para investigações empíricas relativas a populações específicas.

Parece-nos destituido de racionalidade científica um empreendimento que busque investigar sujeitos com vistas à produção de conhecimentos sobre estes sujeitos, antes que a temática de investigação esteja suficientemente assentada como campo teórico.

Seria o mesmo que, por exemplo, produzir-se um trabalho sobre as razões do desmame precoce em puérperas da região $\mathrm{x}$, sem que na reflexão teórica sobre Saúde Pública, Nutrição em Saúde Pública e Educaçāo em Saúde Pública, houvese consenso sobre o valor do aleitamento natural.

Assim sendo, não se pode, desse trabalho, deduzir um conhecimento sobre o "sentido do medicamento para os pacientes hipertensos". Os depoimentos dos pacientes hipertensos, neste trabalho, não aparecem - a não ser marginalmente - enquanto contribuição para o conhecimento do sentido do 
medicamento para o hipertenso mas, ao contrário, como contribuição do hipertenso para o sentido do medicamento (ver:III.14: "O hipertenso como consumidor exemplar . de medicamento".)

\subsection{2. - Pesquisa qualitativa}

Agumas razões fundamentam a presença, neste trabalho, da pesquisa qualitativa, entendendo-se por pesquisa qualitativa, neste caso,basicamente, uma investigação que elege como prioritárias a profundidade e a literalidade do depoimento dos sujeitos (v.QUEIROZ $(62,63)$ e que utiliza o que BECKER (7) chama de "dados ricos,ainda que não sistemáticos".

Estes "dados ricos", no nosso caso, são constituidos,basicamente,por textos publicitários (propaganda de medicamentos em revistas médicas,na televisão, no rádio; propaganda de empresas de prestação de serviços de saúde,etc.), artigos de jornal ou revista, reportagens, bulas de medicamento, folhetos de propaganda de produtos naturais e outros.

Estes "dados" envolvem informação veiculada através de signos ou associaçōes sígnicas de caráter arbitrário (ou convencional) como as mensagens verbais, e de caráter motivado (ou analógico* ${ }^{*}$ como fotografias, desenhos, cores,disposiçōes espaciais,etc.,ou de caráter misto, que combinam "arbitrariedade" com "motivaçāo" (por exeplo, palavras + imagens fotográficas).

\footnotetext{
- A oposição : arbitrário/motivado diz respeito à relaçōes entre o significante (a parte concreta, material, do signo, ou símbolo, ou ícone)e o significado (a parte ideal, ou conceitual do signo, ou símbolo ,ou f́cone). Diz-se que um signo é arbitrário quando seu significante não mantém qualquer tipo de relação natural com seu significado, sendo portanto convencional a relação entre êles.Ao contrário, um signo é motivado quando seu significante (por exemplo, a cor verde) tem algo a ver com seu significado (por exemplo, a ideia de natureza). Ver a respeito TODOROF (76).
} 
Fica claro portanto que a pesquisa qualitativa diz respeito ao trabalho como um todo e não apenas aos depoimentos dos pacientes hipertensos. Isto em funçáo da natureza mesma do trabalho,ou seja, ao fato de que seu objeto central -o sentido do medicamento- é analisado do ponto de vista do social, do ponto de vista do individuo e, marginalmente, do ponto de vista do médico.

Portanto, o empírico, neste trabalho, diz respeito tanto a depoimentos de pacientes hipertensos quanto à propaganda de medicamentos em perídicos médicos, bulas, adesivos, propagandas de televisão, depoimentos de médicos e outros dados, que constituem a matéria documental (V. Anexo) sobre a qual se apoia o trabalho,para o levantamento de hipóteses sobre o sentido do medicamento.

No que diz respeito aos pacientes hipertensos,foram escolhidos para entrevista clientes, de ambos os sexos, matriculados no Centro de Saúde "Geraldo de Paula Souza", da Faculdade de Saúde Pública, no programa de . controle de hipertensão, na faixa etária adulta (a partir de 20 anos).

Foram selecionados para análise, dentre as entrevistas realizadas - excluidas as entrevistas de pré-teste do instrumento - douze depoimentos .

Como o que interessava nos depoimentos dos hipertensos era, basicamente, o seu convívio com o medicamento, foram excluidos da investigação aqueles pacientes que tinham convivência recente como medicamento (menos de um ano).

Por que paciente crônico? 
O paciente crónico, acompanhado por serviços de saúde é alguém que convive com o medicamento. $O$ medicamento $\varepsilon$, pois, para este paciente, um objeto que faz parte de sua experiência cotidiana de vida. Isto dá uma característica especifica a este tipo de consumidor de medicamento, que 6 importante para a finalidade deste trabalho.

Enquanto paciente crônico, o hipertenso é um consumidor crónico de medicamento, o que permite obter, com facilidade, por seu intermédio, dados sobre o sentido do medicamento na medida em que, para este individuo, o medicamento é um objeto extremamente familiar.

Por que paciente crônico hipertenso?

O paciente crónico hipertenso é um tipo especial de paciente crônico na medida em que a hipertensão é uma condição orgânica que nāo se traduz, necessariamente, por sintomas que possam configurar, para os pacientes, em incômodos.

Nesse sentido, este paciente apresenta uma característica peculiar que merece ser resgatada e que está ligada ao fato dele ser, algumas vezes, o consumidor de uma mercadoria cuja "necessidade" correspondente é problemática.

Ora, este fato é, para nós, em função da perspectiva teórica adotada (que, entre outras coisas, questiona o conceito de necessidade e o de consumo - ver 1.1.6.:"Saúde e necessidade de saúde"),um fator que justifica a escolha do hipertenso como população-alvo

Os depoimentos foram coletados através de entrevistas abertas com roteiro (anexo). 
Foi utilizado gravador para registro dos depoimentos.

$O$ instrumento foi pre-testado em pacientes crónicos e nåo crônicos do Centro de Saúde "Geraldo de Paula Souza".

Para se chegar à forma definitiva do roteiro de entrevista aberta passou-se por duas versões preliminares do instrumento que tinham, ambas, o caraterístico de contgerem perguntas ou situações estimuladoras mais "fechadas" que, por conseguinte, conferiam um cunho mais dirigido ou diretivo à entrevista.

A idéia inicial era se obter a expressão mais concentrada do entrevistado em relação ao sentido que ele conferia ao medicamento.

Percebeu-se contudo que este tipo de instrumento não produzia os resultados desejados; ao contrário, este tipo de perguntas ou situaçōes estimuladoras introduziam, na situaçāo de entrevista, um clima de formalismo e constrangimento relativo do entrevistado, que inibia a sua expressão mais aberta e livre sobre a temática.

Por esta razào,optou-se por um instrumento mais aberto e, além disso, por um grau maior de liberdade ao entrevistador na condução da entrevista.

As entrevistas foram todas -com uma única excessãorealizadas no domicílio do entrevistado, com o objetivo duplo de:

-descaracterizar qualquer tipo de situação de "cobrança" da parte do pesquisador, em relação ao cumprimento ou descumprimento das recomendações médicas e 
-permitir um clima menos "médico" - que possivelmente estaria presente se a entrevista fosse realizada no Centro de Saúde - e mais propício ao relato de vivências pessoais, cotidianas, enfim, "dométicas", sobre o medicamento.

Basicamente, duas perguntas funcionavam como "estímulo" para obter-se o depoimento dos entrevistados: a questão 1 (referente ao histórico da doença) e a questão 2 (referente ao significado do remédio na vida do entrevistado).As outras questões entravam no decorrer da entrevista, no momento considerado azado para destacar ou fazer emergir o sub-tema a que se referia a questão.

Por conseguinte, nossa intenção precípua na entrevista era a de criar um clima familiar, distendido e amistoso, para que a vivência do depoente, sobre o sentido do medicamento, fluisse o mais livremente possível

A insistência, que às vezes se fêz necessária por parte do entrevistador, na busca de maiores informaçōes sobre aspectos específicos do depoimento,não implicou em "condução" ou indução de respostas, já que a situação de entrevista permitiu afastar qualquer suspeita, da parte do entrevistado, de se estar buscando (e menos ainda de se estar tentando "arrancar") respostas "certas", "verdadeiras" ou "desejáveis".

\subsection{3. - o Cotidiano}

Umas das razōes que está na base da escolha da metodologia qualitativa para a parte deste trabalho em que se busca estabelecer o 
"ponto de vista do indivfduo sobre o medicamento" (Capftulo III), advém de fato de que se busca, em alguma medida, investigar o universo da convivência cotidiana com emedicamento.

LUDKE e ANDRE * (47) na obra "Pesquisa em Educaçăo: abordagens qualitativas" citando BOGDAN e BIKLEN, colocam algumas das características da pesquisa qualificativa, dentre elas o fato de que "o interesse do pesquisador (qualificativo) ao estudar um determinado problema é verificar como ele se manifesta nas atividades, nos procedimentos e nas internações cotidiąnas" (pag. 12) (grifos nossos).

\subsection{4. - Entrevistas livres}

A busca do sentido desta convivência implica, metodologicamente, em entrevistas livres ou abertas.

Nesse sentido, como afirma QUEIROZ (62): "O primeiro passo será colher depoimentos através de entrevistas gravadas, mantendo com a máxima fidelidade as próprias expressōes dos informantes e sua maneira de encadear os fatos; portanto entrevistas livres. Segundo Roger Bastide, a "técnica da liberdade" revela muito mais a realidade, mesmo quando sob a aparente desordem, do que entrevistas muito dirigidas ou questionários. As intervençōes dos pesquisadores serāo feitas somente quando se mostrar necessário; por exemplo, quando o informante descreve uma passagem peculiar de sua vida, podemos pedir maior precisão sobre a época do acontecimento, ou sobre as pessoas envolvidas".

É claro que a expressão não é totalmente livre porque

- LUDKE e ANDRE, na mesma obra afirmam: "O significado que as pessoas atribuem à coisas e à sua vida são focos de atenção especial pelo pesquisador" (pag. 12). 
está circunscrita à temática da pesquisa, o que tem certas implicaçóes metodológicas. Como afirma QUEIROZ(61) "ainda em relaçăo aos depoimentos pessoais, podemos concluir que muito embora apresente caráter de năo diretividade, pelo emprego da "técnica da liberdade", cabe ao pesquisador ter claramente definidos os problemas a que se propõe investigar e o roteiro dos temas que pretende tratar com o pesquisado. Este roteiro precisa ser flexfvel, de modo a permitir ao pesquisador a incorporação de novos temas, que muitas vezes surgem do proprio relacionamento pesquisadorpesquisado, ou, em outras palavras, temas que surgem no decorrer da própria entrevista".

\subsection{5 - Acão com sentido $x$ sentido da ação.}

Um ponto no âmbito metodologico desse trabalho nos parece importante assinalar: diz respeito ao papel da entrevista aberta (68) frente à oposição: ação com sentido x sentido da ação.

Assinala CALDEIRA(15) "A entrevista aberta não é um acontecimento corriqueiro, mas um momento especial, no qual as pessoas são arrancadas do imediato do cotidiano vivido ao serem solicitadas a considerar assuntos dos quais não se fala todos os dias, a relacioná-los, a olhá-los de longe, em uma palavra, o que se pede as pessoas é "parar para pensar" (pag. 114) (grifos nossos).

Parece-nos importante assinalar que a idéia de que, na entrevista aberta, "as pessoas são arrancadas do cotidiano vivido..." expressa uma posição do que merece ser matizada.

No caso de uma pesquisa como a presente, em que se busca resgatar a vivência cotidiana com o medicamento, esta entrevista pretende, ao 
contráro, ser uma oportunidade e um instrumento através do qual se busca reduzir ao minimo a distância entre a açăo com sentido que e vivida no cotidiano e o sentido que o depoente atribui a esta acấo em seu depoimento.

E evidente que a entrevista aberta sobre o vivido pressupõe um distanciamento entre vivido e a sua expressão na entrevista. Sem dúvida a entrevista (a aberta inclusive) é um momento de reflexão sobre o mundo, é um parar (de viver) para pensar o vivido. O problema está em que às vezes como no caso presente, não se busca "arrancar as pessoas do imediatismo do vivido" mas ao contrário, o que se quer é que elas permaneçam o mais próximo possível desse . imediato vivido, para que se possa recuperá-lo da maneira a mais intacta possível, enquanto ação com sentido. Podemos comparar, idealmente, esta ação com sentido e a entrevista aberta a um objeto que o arqué́logo busca recuperar, preservando o máximo possível a sua integridade como objeto.

Em nosso caso, a ação de consumir cotidianamente um medicamento está sempre acompanhada ou impregnada de um determinado sentido, que faz parte da vivência cotidiana do paciente hipertenso: é esse sentido que se busca recuperar através da entrevista aberta.

E claro contudo que fora das técnicas antropológicas de observação participante, não há outra maneira de obter-se esta vivência que nāo seja através de um discurso verbal do entrevistado sobre essa vivência. 
Ora, a partir do momento em que temos um discurse, do paciente, sobre sua vivência, numa situaçăo de pesquisa, estamos nos distanciando do nosso ideal que é o de, através de um discurso da vivencia, recuperar, intacto, o sentido que acompanha esta vivência no imediatismo do cotidiano.

O que se busca então, através da entrevista aberta, é que o discurso sobre a vivência se aproxime o máximo possível do discurso da vivência.

\subsection{6. - Vivência e subjetividade}

Foram colhidos depoimentos de pacientes hipertensos que relataram suas vivências em relação aos temas do presente trabalho.

A experiência subjetiva que emerge destes relatos, segundo DENZIN (26), não significa que se pretenda "psicologizar" o fenômeno.

A opção por esta linha de trabalho,com suas consequências metodológicas, deriva de nossa percepção de que o campo da Saúde Pública e da Educação em Saúde Pública, encontram-se, grosso modo, na situação descrita por BECKER (7),a propósito da história de vida mas que, cremos,se aplica à pesquisa qualitativa de um modo geral. Afirma o autor: "a história de vida (...) pode . ser importante no momento em que uma área de estudos tornou-se estagnante, as investigações prosseguem, envolvendo um número pequeno de variáveis, com precisáo crescente, recebendo-se no entanto incrementos minguados de conhecimento para o desenvolvimento do campo. Quando isso ocorre os investigadores devem proceder coletando documentos pessoais que sugerem novas variáveis, novas questões, usando dados ricos, ainda que não sistemáticos para empreender a desejada recuperação do campo" (pag. 424). 
CAPITULO I - O MEDICAMENTO DO PONTO DE VISTA DO SOCIAL 
I.1 - Saúde como mencadoria 


\subsection{1 - Saúde come bem de consume}

Como passo inicial na busca do sentido do medicamento na nossa sociedade é necessário indagar do sentido da Saúde, que $\epsilon$, segundo cremos, o campo socio-semântico ao qual está vinculado o medicamento.

Com este fim, pretendemos, neste capítulo, explorar as consequências do fato empírico, constatável pela simples observação do senso comum, de que a saúde está, na nossa sociedade, associada a bens de consumo que aparecem como propiciadores de saúde: medicamentos, seguros saúde, yogurtes,etc.

Ou seja, de que a saúde faz parte, na nossa sociedade, do funcionamento corrente do sistema produtivo de bens de consumo. O que equivale dizer que a saúde (através das mercadorias de saúde) é um produto a venda no mercado, da mesma forma que o transporte individual(através do automóvel), da mesma forma que o abrigo, (através da moradia), da mesma forma que o lazer (através da televisão).

Nesse-sentido, a saúde pode ser entendida no Brasil como uma resultante da sociedade na condição de máquina de produção de mercadorias.

Vejamos alguns exemplos de como a saúde aparece, na qualidade de bem de consumo nos meios de comunicação.

A saúde é: o alho que imuniza, as novíssimas curas do câncer, a vacina certa para a alergia ao pó, o remédio que desperta o desejo sexual, a dieta da associação americana do coração, o Lithotriper da Amico, os tratamentos da Clínica Adventista de São Roque, os SPAS, ou seja "centros de tratamento de 


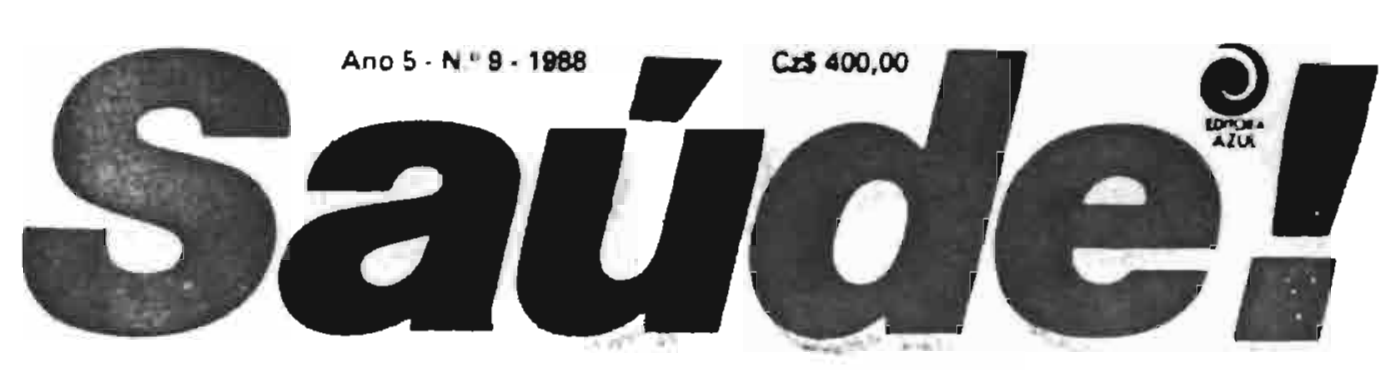

O LANCE

DA IMUNIZACÇÃO NATURAL
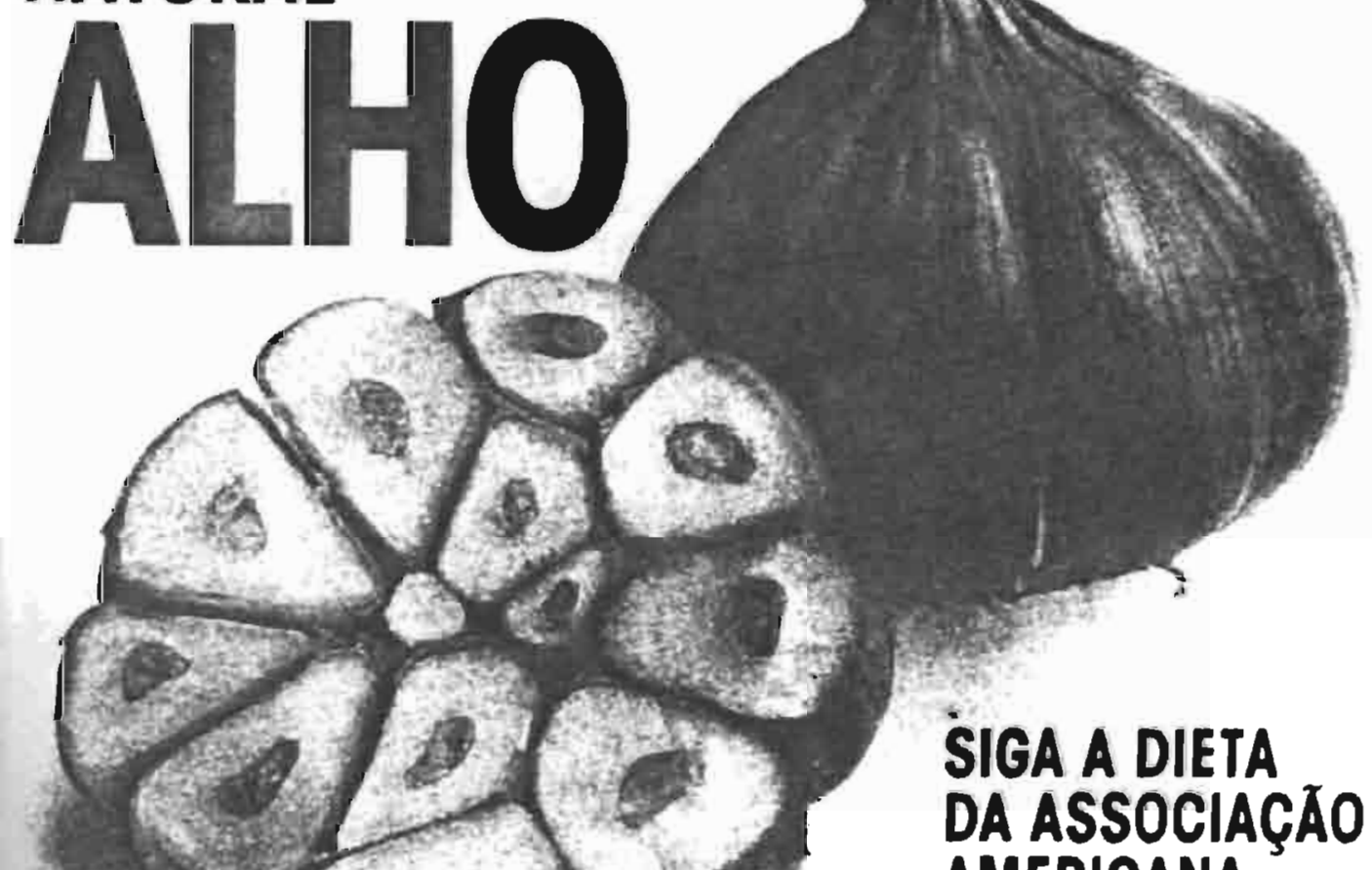

SIGA A DIETA

DA ASSOCIAÇAOO AMERICANA DO CORAÇÃOO

IS NOVISSIMAS CURAS DO CANCER IDO SOBRE O MIRACULOSO ORETO DE MAGNESIO ERGIA A PO: ACERTE A VACINA
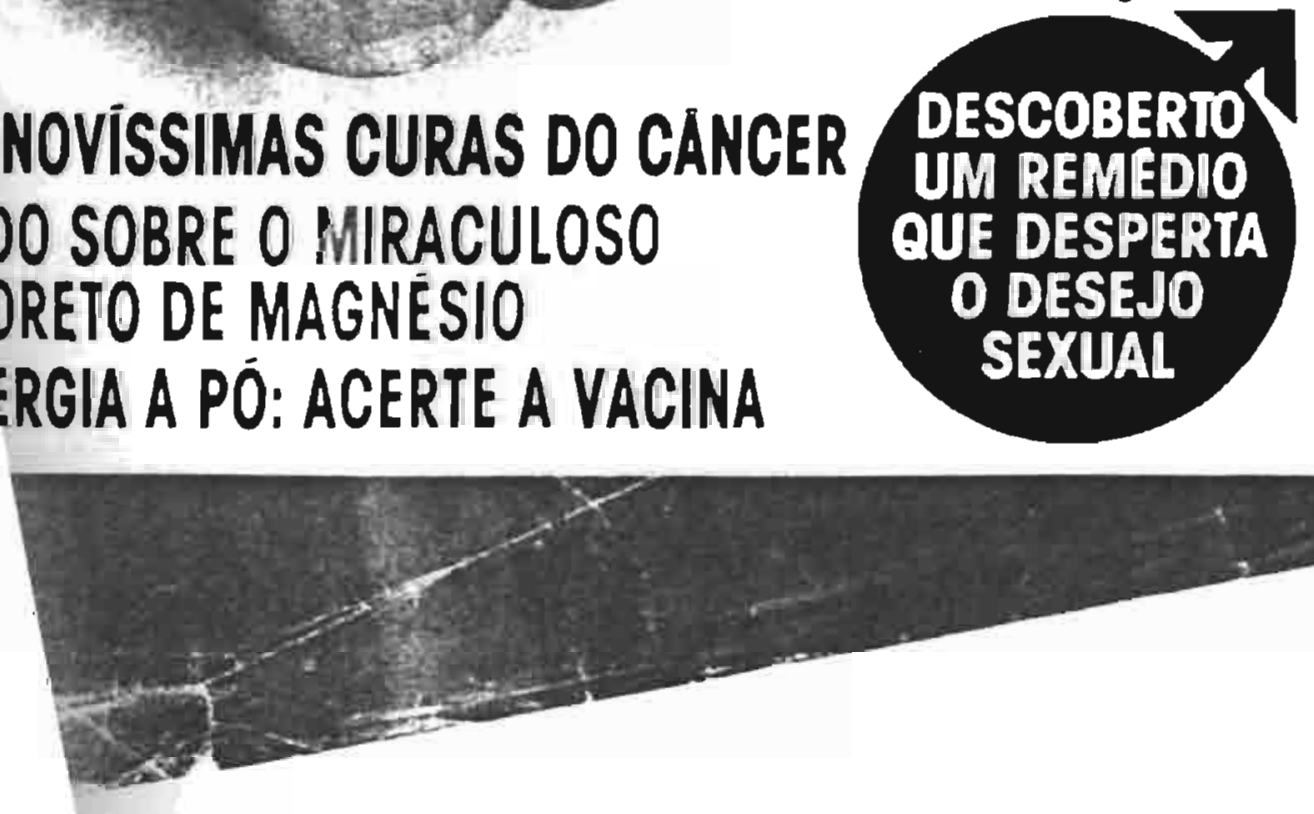

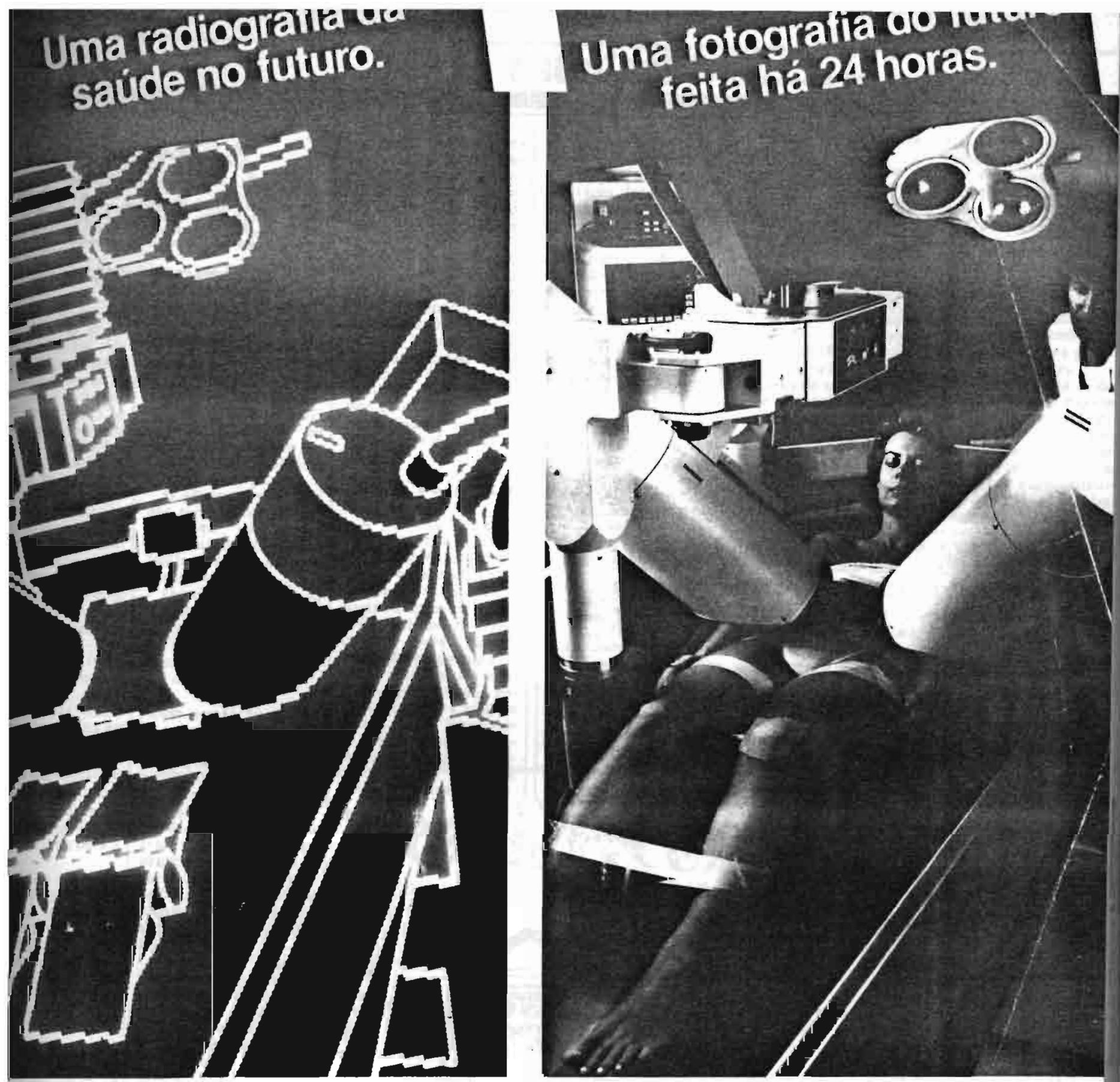

\section{$\mathrm{Na}$ AMICO, o futuro chegou ontem.}

uturo a saúde de todas soas vai ser cuidada com equipamentos is e com a mais alta ogia. Vai ser cuidada é na AMICO.

26 anos a AMICO vem antando no tempo, cionando a seus ciários o que há de Ivançado em termos dicina. A exemplo a AMICO montou no lal Indianópolis o seu iovo centro de ogia para cuidados saúde. E o Centro de rento de Cálculos 5. No CTCR está instalado o Lithotripter, o único aparelho destinado a fragmentação de cálculos renais sem cirurgia,

realmente com resultado comprovado e aprovado pela FDA (Departamento Americano de Administração de Alimentos e Drogas).

A AMICO através de sua estrutura própria garante sempre o mais alto nivel de atendimento para seus beneficiários, dando-Ihes a certeza de que em todos os setores da medicina, o futuro chegou ontem e está à sua disposição.

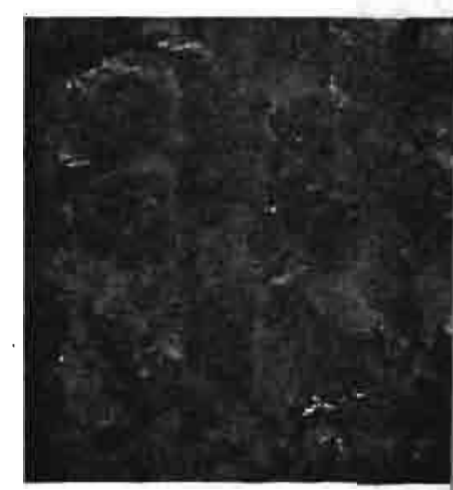

-1. 0 MÉDica SEM SADDE NINGUEM TEM FUTUR 


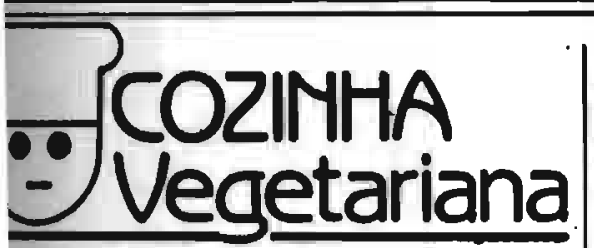

\section{Crie e economlze}

7 to melo 1 carostis coral - $n 0$ corte to subs/dio de sha de trigo, deterdo pelo governo, -de-casa ostará omizando (c o no tempo ajudando mbeter a inf!aç5o) user produtos da 1, mais baratos.

es e bolos diferengostosos podem ser especialmente época do ano, ido produtos como fioca, batata doce, inhame estio com os convidativos em s, supermercsdos e

farinha de trigo ser parcialmente ituida por esses lentos e até commeate pelo fubá ou he de mandioca iversos pratos. Asempenhando seu co nu ma edaptaç lo proporcionars alikio variada para a pảo feito em casa this saboroso e a u 0 , pois voce meserifica qualidade ugredientes que irs ir no seu pre paro. is vezes, fica afé barato que 0 inlalizado.

Fariabaa

inka de trigo inse Quando pura, fica pegajosa ermile wer sovada. duto $t$ duro e peEsta farinhe neade maior quantide Ilquido na hora eparo de ples, pois ve bastante igua. tho de centeio. ante a farinba de niegral.

de wilho. Muito gudo ae fabricaples $\infty$ m ferquímico em pó. tha de soja. Mea valor nutritivo 1. quando adiciola proporço de dus colheres para cada xlcara inha de trigo.

Intritive

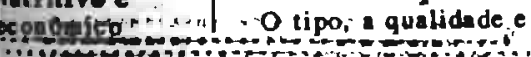

Farinha. Pode-se usa qualquer tipo. A de trigo de ve ser molda. Outras farinhas, como centeio, germe de trigo, farelo, fubl, farinba de milho, necessitam de mistura de farinba de liga.

Femento. E o ingre diente responsável pelo crescimento do páo. H dois tipos: fresco, encontrado em tabletes ou solto, em estabelecimentos comerciais. Se esfarelar facilmente esif bom para uso. Conserve-o em geladeira granulado em po: concerve-o sempre em lugar seco e longe do alcance da luz.

Sal. E o ingrediente responsável pelo sabor do păo.

Llquidos. A quantidade correta é muito importante, pois o excesso ou falta deste ingrediente resultarf́ num pĩo de miolo e casca fs peros.

Gordura. É responst vel pela maciez do plo. Quantidade exagerad desse ingrediente poderf resultar num pao es ponjoso.
- quentidado dos ingredientes wo fatores im. portantes quanto no valor nutritivo do plo caviro. Substitua com su cosso esses ingredientes ne aue recelte.

A f́gue pode sor substitulda por leine, Igua do coziroento de horta liças (abobbors, batata sert, mendioquinhe, inbeme, batata doce. mandioce), caldo de lepuminosas (felfo, soje. lentilha, orvilha): sleo pela banha vegetal margerina, gordur mimal derretide (toueinho).

Misture e enriqueça

A farinha de trigo cort ém glúten, subsinncis que permite a mass, ap6s sovada, incor porar ar para fermentar e portanto ctescer.

A farinba de trigo integral pura, quando utilizada no preparo de píes, resulta numa mas la pegajosa que nāo pode ser sovada e assim gláten nāo se desenvolve. Por este motivo, de-

O pão é preparadc ve cer usada com apro-
Dovo-so usar, einde, quido, je qua a farinhe de trigo Integral tem meior anpecidade do absorclo.

A larinhe de contelo ato conkm gloten - 6 usade tambern com farlwhe branca, na mesma proporclo que ariahe de trigo intogrsl.

O fuber de milho 6 utillzado no preparo de plos com fermento qufmico em pó e resulta num plo mais leve quando contém ate $50 \%$ de farinhe brance.

Deve-w user, ainde, maior quentidade de llquido, ju que arinha de trigo integral tem maior quantidade de If

mator capacidado do absorçlo.

o fuba de millho utilizado no preparo do ples com fermento qui mico om pó e resulia num plo mala love quando contem atd $50 \%$ de farinhe de trigo brance ou integral.

De mesme forma, farinha de soje of utill zade nume proporglio de 1 . 2 colheres de (sopa) para cada xicara de farinha de trigo branca. com o intulto do enriquecer a preparaçio. que possui alto teor de protefnas.

A farinhe de soje tambem dím contém glóten, mas sua protel na complementa do

\section{ALIR'TA BRASIL!}

\section{NÄO HACA DO ALIMENTO O SEU TORMENTO}

Extraia a sordura dos embutidos, a solanina da batam E inglesa, os gases da batala doce, as soxinas das carnes. verduras e legumes e cozinhe 5 pratos cam $\mathrm{um}$ só bico de gas em 10 minutos, eliminando bleo, gordura e rempero. pelo processo "Avto Cooker" (cozimento a vapor). O inventor, que ven se dedicando em dar aulas próticas e palestras sobre este lema, quer estende-las Junto ds prefelituras, unidades do exército. hospliais, associaços de senhoras donas de casa.

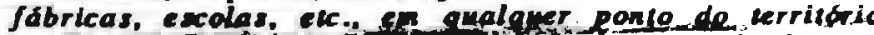

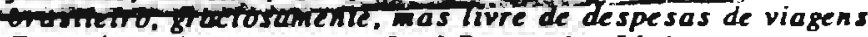
farinba branca. I Fone: (OII) 220-0775 cam Jost Bernardes Jinior. trigo branca para dar

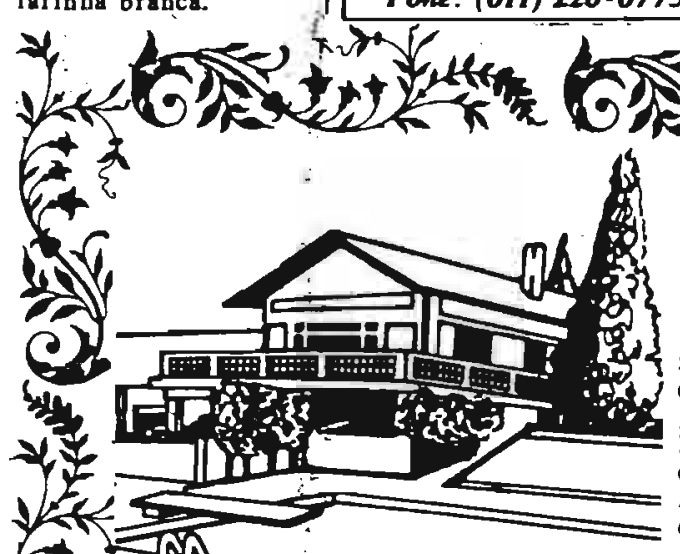

\section{+ an}

L A Cllnica Adventizta de S5o' Roque é especinlizade em tratamento de hidroterapia que inclui sauna seca

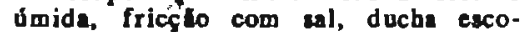
cest e masagem geral. Alem disto conforme houver indicacto do medi co, o cliente podert fazer banhos de ervas, banboa de luz, cataplasmas, chí e aplicaçöea de ervas medicinuis.

1 fisioterapin, etc.

1 fisioterapin, etc.

ff Na Clfaica Adventista de Sio Roque

PROJETO tot

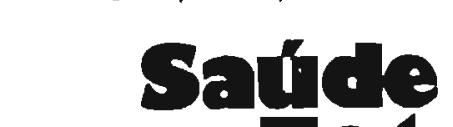
samente para: obesidade, ( ) gestivas e circulatorias, bronquite hibito de fumar e beber, reumatismo c outras doenças crónicas.

P.léra do tratamento o cliente parti. cipa de um programa intensivo de Aude que $t$ o PROJETO SAUDE TO$T A L$, onde ele terá todas as informaçö: necesturis manter a cá́de.

Pare melores hiormesbes preenche e remels - cypom batro:

None

Endereso CEP

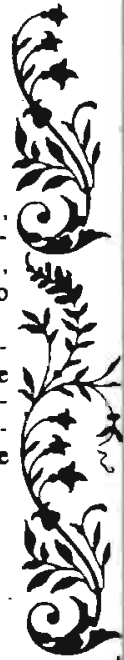

Cr. Poile 00 - CEP 18.140 - biün - SP.

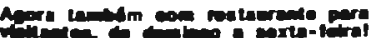

O Projere Sacide Total consiste num perfodo de 15 dias de intérnaça com - aeguinte programa: - Caminhadas e ginástica; Hidroterapia; "Culinfria vegetariana; - Curao de Tratamentos Naturaia; Terapia Ocupacional (cultivo de ervas medicinais); "Videocassete; "Palestras MÉdicas.

VAGAS LIMIT ADAS: RESERVE A SUA PELOS FONES: (011) 279-8647 499-1221:425-7100.

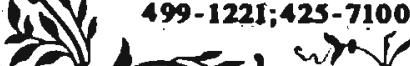




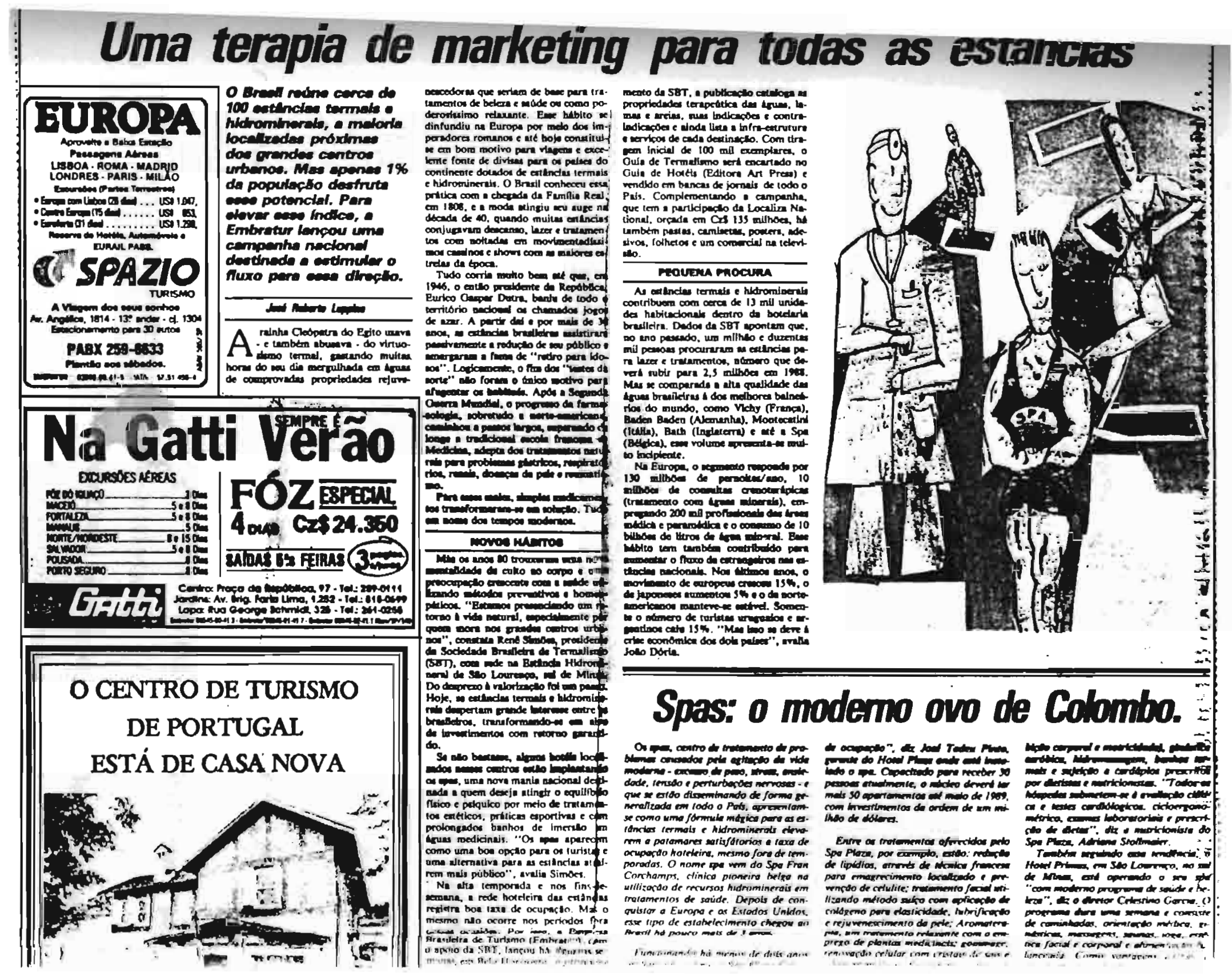


problemas causados pela agitaçăo da vida moderna - excesso de peso, stress, ansiedade, tensåo e perturbaçôes nervosas, que se eståo disseminando de forma generalizada em todo o pass".

Note-se que todas estas peças de propaganda (que. constituem pequena amostra de uma infinidade de outras peças semelhantes) são, explicitamente, definições sociais de saúde onde esta aparece incorporada a mercadorias e serviços que a representam, de tal sorte que é perfeitamente legítimo sintetizar o sentido destas peças como o fizemos, ou seja: "a saúde é: (nome do serviço ou mercadoria)".

A título complementar vale ainda mencionar algumas peças publicitárias $(1988,1989)$ com o mesmo teor:

- "Droga Raia: saúde é a nossa preocupação" (propaganda em farmácia; "lema" da farmácia);

- "máscara para os olhos Termo Gel - Beleza e Saúde para os seus olhos" (propaganda em ônibus);

- "Ligue para a saúde, ligue para a "Blue Life" (propaganda em rádio);

- Tome uma atitude saudável.Ligue para a Amil:dois,tres,um,mil" (propaganda de televisão);

- "Golden Cross : saúde em primeiro lugar" (adesivo);

- "Saúde: quando é preciso levar para o hospital" (sub título de revista -Pais e Filhos 2,1988)

- "Eu tenho Saúde Bradesco" (adesivo);

- "Yogurte Danone ssua dose diária de saúde" (rótulo de yogurte); 


\section{- "Yacult: o doce gostinho da safde" (propaganda de}

televisåo).

\subsection{2. - Saúdemercadoria alienaçá e reificacåo}

De acordo com a perspectiva teórica adotada, a saúde pode ser vista nas sociedades capitalistas como a brasileira como um ente exterior do tipo mercadoria. Define MARX, in: HORTON (39) à mercadoria como: "...antes de mais nada, um objeto externo, uma coisa que, por suas propriedades, satisfaz as necessidades humanas, seja qual for a natureza, a origem delas, provenham do estômago ou da fantasia" (pag.53) (destaques nossos).

Para entender a saúde como um ente exterior, a mercadoria, e para comprender o que isto significa devemos introduzir os conceitos de alienaçāo e reificação.

O que na teoria marxista aparece como processo de alienação e reificação segundo HORTON (39) pode ser descrito como crítica da separaçāo do homem e da sociedade: "Marx acentuou o lado humano e ativo da relação homem-sociedade, negando radicalmente o dualismo. A atividade social e humana do homem é o seu trabalho; os produtos do trabalho, incluindo a sociedade, são extensōes da própria natureza bumana. Portanto o homem é a sua atividade, é seus objetos, o bomem é a sociedade. Qualquer reificação dos objetos humanos, qualquer transcendência do produto dos homens sobre êles mesmos (destaques nossos) que os impeça de visualizar seus interesses, suas babilidades e seu poder ali expressados e afirmados, vem a ser a evidência da alienação do homem de sua . própria atividade, de seus objetos, de si mesmo. A noção total de alienação do social pressupõe esta concepção imanente da natureza bumana. 
"A alienaçâo é um estado histórico (...) A obra de Marx poderia ser interpretada como uma análise empirica do processo histórico no qual o homem se torna separado e reunido à sociedade como individuo" (pag.97).

A área da saúde, no capitalismo, não escapa da alienação e da reificação $(23,32,48,56,61,74,80)$.

No que tange especificamente à medicina QUEIROZ (61) ilustra este processo ao afirmar: "Sob o ponto de vista da relaçāo médico paciente, o desenvolvimento da medicina ocidental moderna tem sido visto como um processo pelo qual o paciente perde a sua integridade e consciência de si mesmo e se torna objeto de manipulação" (pag 312).

\section{I.1.3 - A saúde e a tensão entre o bem e o mal}

A saúde só passa a ter sentido, no contexto de uma sociedade alienada, dominada pela mercadoria, quando acoplada à doença, ou à ameaça de morte, ou à dor, ou ao desprazer, ou à feiura, ou à fraqueza. São estas (e outras) condições negativas que fazem a saúde existir, com sentido, na sociedade da mercadoria, porque a lógica da mercadoria, que pontifica, é a de negação do negativo.

Com efeito, qualquer produto ou mercadoria ou serviço aparece sempre, socialmente, provida, nas formaçōes sociais capitalistas, do sentido ou significado básico, que the confere o senso comum, de coisa "benéfica", que aparece como "solução" de uma situação ou estado malefico prévio ou como recurso para evitar o surgimento de estados ou situaçōes como a doença, a morte, a miséria,etc. 
Os produtos alimentícios sáo entidades benéficas cujo sentido t "solucionar" estados maleficos como a fome, para conduzir a estados benéficos como a saciedade; a casa é vista como um bem para evitar o mal do relento; da mesma forma que o "bom cobertor existe para evitar o "mau frio"* , a escola para evitar a ignorância** e assim sucessivamente.

A saúde nāo foge à regra: só existe com sentido, na e para a sociedade da mercadoria porque faz gerar produtos cuja funçāo maior é fazer face à situaçāo ou estado maléfico antagônico ao estado de saúde.

E este, segundo cremos, o fundamento que permite a LUZ (48) afirmar: "Ao se falar de saúde.... esta-se falando num setor de instituições do Estado que se ocupa da prevençāo ou cura das doenças das camadas mais amplas da população. Tal concepção aparece referida não propriamente à sanidade, ao "bem estar", mas, ao contrário à doença. Doença que tem que ser controlada, ou prevenida senão eliminada" (pag.61).

Nas formaçōes sociais capitalistas, como a brasileira, o sentido das mercadorias de saúde (dentre as quais o medicamento) $\varepsilon$, portanto, o de aparecer como "solução" de uma tensāo entre estados humanos antagônicos: um estado "mau" de carência ou necessidade* ** de saúde um estado bom de satisfação,

\footnotetext{
- Há alguns anos atrás, havia, na televisão brasileira, uma peça publicitária de cobertores das Casas Pernambucanas em que o "frio" aparecia como figura má, para destacar, por contraste, o caráter benéfico do cobertor.

** Que esse sentido "natural" e a-historico das mercadorias e serviços não o é, de fato, ficou patente em alguns estudos clássicos sobre a função social da Escola. Contrariamente à idéia do senso comum, a Escola não existe para evitar a ignorância mas para reproduzir as estruturas sociais existentes. A respeito, ver ALTHUSSER(1); BOURDIEU e PASSERON (11) .

$\star \star \star$ Neste trabalho não se discute, a nivel conceitual, necessidade.Portanto, não se opta por qualquer . conceito de necessidade; não evidentemente porque se considere esta discussão irrelevante, mas simplesmente porque o que se procura mostrar aqui é a manipulação "produtivista" da necessidade (na
} 
que podemos sintetizar como ENs-Ps Es, ou seja, Estado de Necessidade de saude Produto de saúde - Estado de Satisfaçáo de saúde.

\subsection{4 - A ampliaçáo de grau de recessidade de saúde}

Mais genericamente podemos colocar que para a saúde ser oferecida como mercadoria - que $\boldsymbol{\epsilon}$ a Necessidade do Sistema em sociedades como a nossa - é preciso que se amplie o grau da sua inexistência nos indivíduos, é preciso que os indivíduos tenham expandido o seu grau de carência de saúde.

Nesse sentido, vale como ilustração uma reportagem da revista Manchete (20) intitulada: "Como perder peso e ganhar saúde: a dieta ideal". Afirma-se na reportagem:"

Finalizando esta série, Manchete, publica agora tudo o que você precisa saber para montar a sua dieta ideal. Com ela, se obeso voce vai emagrecer. Se já é magro, coquistará o peso que sempre sonhou. Se é dono de um fisico perfeito, além da boa forma, você vai adquirir mais saúde e diposiçāo, mais imunidades contra as doenças, sem falar na alegria de viver, uma consequência natural de tudo isso."

O comentário mais obvio que se pode fazer a respeito deste texto é dizer que literalmente todas os leitores da reportagem se enquadram no grupo (teoricamente composto por todos os seres humanos) dos carentes ou necessitados de saúde: os magros, os gordos e os de físico perfeito. Vale notar

acepsão do senso comum), tal como é expressada (e confessada), sinteticamente, na nota de rodapé da página 69. 
também a presença do que poderlamos chamar de "saúde elástica" $\star$ : ("mais" saúde e disposiçâa", "mais imunidades contra as doenças") e da saude como sonho: (a "alegria de viver" e o "peso que sempre sonhou").

Outra ilustração da plasticidade do conceito de saúde e de necessidade de saúde pode ser dado pelo folheto publicitário do BIO da Danone(anexo). Nele é dito:

"A flora lactica viva do Bio da Danone facilita a digestāo, pois apresenta proteinas pré-digeridas, que melhoram o trânsito gástrico $e$ o bem estar digestivo. Bio da Danone atua:

. na regulagem do trânsito intestinal

. na proteção da flora intestinal

- na reposição da flora após o tratamento com

antibióticos

. no combate à constipação e à diarreia

. na inibição da proliferação dos germes patogénicos

. na desintoxicaçāo intestinal

Bio é altamente nutritivo, ajuda a melhor assimilação do ferro no organismo, além de ser excelente fonte de cálcio e proteinas de alta qualidade, o que favorece a mineralização ossea "

Da mesma forma que na reportagem de Manchete, qualquer indivíduo pode se enquadrar como necessitado de Bio, ou seja como indivíduo nāo saudável ou não suficientemente saudável, pelo modo como o texto coloca suas afirmações.

\footnotetext{
* Como se percebe, a "saúde elástica" é uma idéia feliz, para os propósitos de mercantilização da saúde, na medida em que, sendo a saúde elástica, é sempre possível atribuir aos indivíduos a condição de carentes e necessitados de saúde, ou seja, de produtos de saúde.
} 
Com efeito, quem, em să consciência, pode dizer que o seu "trânsito gástrico" ou seu "bem estar digestivo" năo pode ser melhorado? Quem náo deseja ver a sua flora intestinal protegida? Quem năo quer ver inibida a proliferaçăo de germes patogênicos no seu organismo, ou seu intestino desintoxicado? Quem năo deseja ver o ferro em seu organismo melhor assimilado? Quem pode dispensar uma excelente fonte de cálcio e proteinas de alta qualidade?

Vai na mesma direção o folheto de propaganda das capsulas de 6́leo de alho cru, 6leo de fígado de bacalhau e 6leo de germe de trigo (anexo).

Neste folheto está colocado, como sub-título: "O segredo da vida longa e saudável". Sob este título é colocado:

"O óleo de alho cru, o óleo de germe de trigo e o óleo de figado de bacalhau Naturalis, ricos em nutrientes nobres, tem ação protetora sobre as artérias e proporcionam melhor nutrição e oxigenaçāo das células, evitando, desta forma, os fatores que determinam o envelhecimento precoce do organismo".

Nutrir e oxigenar as células evitando, com isso, o envelhecimento precoce do organismo são, também, propriedades de mercadorias de saúde "irrecusáveis" por qualquer indivíduo normal, ou seja, que não deseja envelhecer precocemente. 


\subsection{5 - Hipertrofia da dimensåo orgânica da saúde}

Os processos de alienaçăo e reificaçăo, para serem adequadamente entendidos devem ser traduzidos para o léxico da saude pública em termos de hipertrofia da dimensāo orgânica da saúde em detrimento das suas dimensōes não orgânicas $(48,80)$. Este processo de hipertrofia é tanto mais eficaz quanto nāo aparece como tal, já que a doença ou a saúde aparecem "naturalmente", "expontaneamente" como fatos orgânicos. E esta aparência é grandemente reforçada na medida em que todo o investimento da tecnologia chamada de "saúde", crescentemente sofisticada, tem seu "locus" de manifestaçāo neste mesmo nível orgânico (incluido aí o mental).

Explorando a relaçāo entre alienação/reificaçāo e hipertrofia do componente orgânico da Saúde/Doença,diríamos que à reificação/alienação, ou seja à hegemonia das mercadorias sobre o Homem, ou seja, das coisas que o Homem faz sobre este mesmo Homem, corresponde o prevalecimento da visāo da Saúde e da Doença apenas como coisas, como "concretudes" primárias.

A Saúde e a Doença como "concretudes" primárias traduzem-se, por sua vez,em Necessidades (dor,fome, calafrios, febre, enfim, sintomas, sensações concretas) e Necessidades Satisfeitas (sensação concreta de alívio da dor, ausência de febre, enfim, anti-sintomas).

Estas Necessidades Satisfeitas, finalmente, fusionam-se, confundem-se com as Mercadorias, instrumentos desta Satisfaçāo, coroando todo o processo. 
A propaganda do medicamento Hepatoviz fornece um exemplo claro deste processo quando afirma que "Hepatoviz é a Saude do seu figado" (da mesma forma que a propaganda da Goldem Cross, quando afirma que "Golden Cross E Saúde em boa companhia).Ou seja, a sensação de saúde do fígado, a saúde do ffgado como estado organico desloca-se para a mercadoria Hepatoviz.

Este processo tem, é claro, um substrato mágico : como o mago, com seu "passe de mágica", subtrai alguma coisa à vista do espectador para que ele tenha a sensação de que "o coelho saiu da cartola", a propaganda de Hepatoviz subtrai, nāo à vista mas ao raciocínio, ao encadeamento lógico, a sensação de saúde do fígado, passando direto (a ideologia ou efeito ideológico é,com efeito, uma espécie de "curto circuito") para a saúde do fígado concentrada na mercadoria ou tornada atributo essencial desta.

Mas este processo não é só isso, não é apenas um truque, um "trompe l'oeil".E mais do que isso, é mais sutil.

Com efeito, como ter a-tão desejada, primária, imperiosasensaçāo de saúde, sem a mercadoria? Afinal, não seria o Homem, por si só, sem a mercadoria (que é a forma histórica secularizada das "poçōes mágicas" do feiticeiro) absolutamente incapaz de auto-gerar a sensação de alívio, o anti-sintoma, enfim, a Saúde?

Com efeito, uma vez que se adentra neste terreno pantanoso, permanece-se preso a uma armaldilha ideológica e conceitual da qual não e possivel escapar sem uma crítica profunda dos conceitos que conformam esta mesma rede (ou armadilha). Um destes conceitos, a ser críticado, é o de Necessidade de Saúde. 


\section{L.16- Saride e necessidade de sarude}

A resultante deste processo de produção social do sentido da saúde é, então, o que poderíamos chamar de Constituição da Necessidade de Saúde.

O conceito de Necessidade de Saúde é o que opera, na produção social do sentido da saúde, a "naturalização" de todo o processo, aparecendo a mercadoria como resposta às necessidades, "naturais"* do homem

Como afirma CORDEIRO (23): Os conceitos de necessidade e consumo médicos" não são compreendidos como um conjunto de necessidades e formas de a satisfazer imutáveis, inerentes à natureza humana e aos requisitos funcionaisda sociedade. São necesidades que se criam, que são cultivadas, inculcadas e conquistadas a partir de práticas econômicas, políticas, e ideológicas que caracterizam as práticas institucionais do complexo médico industrial e das classes e grupos sociais" ( pag.177).

Mais genericamente coloca BAUDRILLARD (6): "Podese generalizar esta conclusāo e se definir as necessidades, quais quer que sejam elas de nenhum modo, segundo a tese naturalista/idealista como força inata (...) virtualidade antropológica, mas como função induzida (em itálicos no original) nos indivíduos pela lógica interna do sistema, mais exatamente, não como força consumptiva ("force consommative") liberada (em itálicos no original) pela sociedade

\footnotetext{
- Em artigo na Folha de São Paulo, sob o título "Na publicidade redator deve transformar produto em desejo, "(55) afirma-se explícitamente"o redator de propaganda (...)deve criar necessidades para o produto e/ou serviço que vai vender" (destaques nossos).
} 
de abundancia, mas como força produtiva (em italicos no original) requerida para o funcionamento do próprio sistema em seu processo de reproduçắo e sobrevida. Dito de outro modo: as necessidades s6 existem porque o sistema as necessitan (pag. 87).

Aplicando estas ideias ao campo da saude dirfamos que definir as necessidades (de saúde) como "funçăo induzida nos indivíduos pela lógica interna do sistema "(que reza que a mercadoria deve prevalecer sobre todas as. coisas), implica na opçao por uma determinada visāo de saúde, que é concebida como ausência, ou ausência da ameaça de doença, dor ou qualquer condição orgânica ("latu sensu") tida como negativa, ausência essa que aparece como uma resposta produtiva, ou resolutiva (no jargão atual da área de saúde), fornecida por mercadorias como medicamentos, cirurgias, tratamentos "naturais", yogurtes,etc. às necessidades de saúde.

O conceito de Necessidades de Saúde é uma peça vital para o sentido da saúde/doença, gerado socialmente nas formaçōes sociais como a brasileira.

Este conceito permite que a saúde se identifique com outras necessidades (de abrigo, de proteção contra o frio, de alimentação,de instruçāo,etc.) e se enquadre na lógica do sistema, a saber EN-P-ES.

E dessa equação semântica evacua-se ou netraliza-se a questão da causalidade social porque se trata de de uma equação fechada, ou autosuficiente: o EN começa o processo* ${ }^{*}$ o produto** dá conta da necessidade e sobrevém o ES.

\footnotetext{
- Ele é original-geneticmente falando - antes dele não há nada.

* Estamos falando de um produto genérico, não de um produto particular. Por exemplo, na frase: "Isto . se resolve com medicamento, ou com antibiótico, "medicamento e antibib́tico" são produtos genéricos.
} 
Nesse sentido vale a pena, como ilustraçăo, recolocar o texto a respeito dos SPAS. Afirma-se na reportagem: "Os SPAS, centros de tratamento de problemas causados pela agitaçăo da vida moderna - excesso de peso, stress, ansiedade, tensão e perturbaçóes nervosas - e que se estão disseminando de forma generalizada pelo país..."

Colocar o problema em termos de "agitaçāo da vida moderna" permite evacuar a causalidade social. Com efeito, a"causa social" adquire aqui contornos de uma fatalidade indeterminada frente à qual não há nada a fazer: o caráter agitado aparece como um atributo constitutivo, inerente à vida moderna, ou seja à vida que se vive hoje. Portanto, a "agitação da vida moderna", causa dos problemas de saúde, aparece como sendo o que é, igual a si mesma, ou seja, não causada.

Sobram assim isoladas, as necessidade (ou problemas) como objetos de intervenção/solução, o que permite às mercadorias ou produtos (no sentido de produtos genéricos) reinarem soberanos, aparecendo como agentes supressores únicos destas necessidades.

Fora deste esquema EN-P-ES, aparecem as contradições e paradoxos. Em nosso país, o paradoxo da saúde (despida do sentido acima colocado, em que os sistemas sociais aparecem como máquinas protetoras, montadas para dar resposta às necessidades "naturais" do ser humano) é que a sociedade, ao produzir, através destas mercadorias, Cuidado, Assistência, Proteção (todas metáforas da fuçāo materna/paterna) está Assistindo, Cuidando e Protegendo a saúde de seus membros * contra as ameaças e os agravos à saúde que são, numa larga medida, produzidos por essa mesma sociedade, em decorrência do seus modo de organização social e econômico. A mesma sociedade que é largamente responsável pela produçāo de 
úlceras e gastrites Assiste a estas condiçôes com Tagamet (ver análise do medicamento Cytotec pag.98).

De acordo com o dito popular, podemos afirmar que "uma mão, do sistema, lava a outra".

Estamos obviamente cientes de que, se este paradoxo ou . contradiçāo, assim enunciado, indica, de um lado, a impossibilidade de resolver a questão da saúde/doença regionalmente, ou seja, no âmbito dos chamados Sistemas de Saúde, por outro lado, não se desconhece que seria muito mais grave se a sociedade, além de produzir ameaças e agravos à saúde, assistisse mal ou assistisse desigualmente a seus membros* .

Porém a injustiça na distribuição de bens de consumo ou serviços, como consultas médicas, odontológicas, medicamentos, exames de laboratório, etc. não é o problema que nos ocupa.

O mesmo que se disse sobre a saúde/doença pode-se dizer a respeito das necessidade de Segurança: a organizaçāo social, numa larga medida, gera insegurança e ao mesmo tempo "vende" a segurança através de mercadorias como revólveres, alarmes contra roubos, estacionamentos para automóveis, serviços de segurança privados ou públicos,etc.

\footnotetext{
" Como assinala MAGALDI (50): "a saúde não pode ser reduzida ao conjunto de intervencốes de natureza médica, preventivas, curativas e reabilitadoras ofertas por servicos de saúde. $E$, antes de tudo, o resultado de formas de organização social da produção, as quais podem gerar grandes dificuldades nos ńveis de vida" (sublinhado no original). Agrega, no entanto, MAGALDI (50): "Essa dimensão real da saúde não nega (...) o componente de servicos de saúde que devem ser objeto de mudanças urgentes para a melhoria da qualidade de vida" (sublinhado no original) (pag. 78).
} 
E interessante notar, neste cotejamento entre necessidades de saúde e necessidades de segurança, que ambas aparecem com 0 . sentido adicional de necessidades prementes, o que é mais um expediente que permite afastar a causalidade social. Quando o assunto "segurança" é discutido nos meios de comunicação de massas, a causalidade social é, quase sempre, relegada a um segundo plano, em face da necessidade premente de fazer frente - com aumento do efetivo policial, mais armas, mais helicópteros, mais prisões - à violência que se manifesta no cotidiano.

Da mesma forma, no campo da saúde, é preciso ser "resolutivo", deixando de lado a causalidade social, porque as doenças exigem soluções prementes.

\section{I.1.7 - A saúde com $s$}

A esta concepção se opōe, dialeticamente, uma outra, a que vê a saúde como produção do sistema social porém concebido não como máquina de produçāo de mercadorias (de todo tipo, inclusive de saúde), mas como expressāo de um arranjo" convivencial", "organizacional" "relacional", dos homens entre si e com a natureza. A saúde, nesse caso, aparece como resultante da organização social como um todo.

Nesse sentido, a saúde se confunde com a ideia de Existir Completamente como Homem; e isto é uma condição humana e não uma necessidade; ou, se se quiser, é o somatório de todas as necessidades humanas (incluindo aí as necessidades - agora totalmente "depuradas" - de assistência médica, odontologica, etc.). 
A saúde desloca-se entâo de"sede", de espaço, de "locus", na sociedade, passando do espaço da mercadoria para o espaço da sociedade como um todo, do espaço do consumo (de mercadorias de saúde) para o espaço do Direito, (à saúde, ou seja a existir completamente como homem).

Retomando e ampliando a distinçāo de LUZ (48)entre Saúde e saúde, diŕamos que nesta concepção a Saúde(s) seria igual ao somatório dos s.i que compōem a organização social.

O fato de $s$ ser um atributo da sociedade como um todo, faz com que o reencontremos em cada um dos s.i.. Assim, a habitaçāo é geradora de saúde, lazer é gerador de saúde, etc. Esquematicamente, temos $s=\mathrm{s} 1+\mathrm{s} 2 \ldots+\mathrm{sn}$ onde o que é chamado atualmente de saúde seria considerado apenas mais um s.i. ou seja, um dos sub sistemas geradores de saúde .

A saúde, sendo um atributo da sociedade global, é, portanto, um atributo do próprio homem na medida em que a sociedade se identifica com este homem, é este homem, no coletivo. A saúde deixa então de estar na mercadoria e passa a estar no homem coletivo e a constituir um atributo deste homem no coletivo.

Retomando as palavras de HORTON (39): "Marx acentuou o lado humano e ativo da relação homem-sociedade, negando radicalmente o dualismo. A atividade social humana do homem é o seu trabalho, os produtos do trabalho, incluindo a sociedade, são extensōes da própria natureza humana. Portanto, o homem é a sua atividade, é seus objetos, o homem é a sociedade " (pag.97) (destaques nossos). 
Confrontando-se entåo esta visåo com a reificada, dirfamos que numa situaçăo estamos diante da saude efetivamente produzida pelo sistema social, gerador e promotor de saúde como seu Dever; em outra situaçáo estamos diante da saúde como uma região institucional do sistema social, especializada em oferecer produtos e serviços para os organismos afetados e afetáveis por processos mórbidos.

\section{I.1.8 - A saúde como aquile que produz saúde}

Considerando como parâmetros estas polaridades dialeticas, a saúde, em nossa sociedade, pode ser entendida, enquanto praxis, como uma constelação de mercadorias produtoras de saúde. Ou seja, entre nós saúde é,hegemonicamente, aquilo (produto,serviço) que produz saáde.

E como os limites do conceito social de saúde são deixados em aberto - o que permite, entre outras coisas, associar saúde e beleza, como nos regimes alimentares, nas cirurgias plásticas "estéticas", em produtos como o já analisado Bio da Danone - a constelaçāo de mercadorias fica também sem contornos definidos.

As mercadorias de saúde (o medicamento dentre elas) numa sociedade onde a mercadoria pontifica passam então a incorporar em si a saúde,passam a representá-la,a simbolizá-la. 


\subsection{9 - A saúde e e ponte de vista}

E importante frizar que a analise do sentido da saúde que fizemos neste capitulo - e que está presente em todo o trabalho -,em conformidade com os princípios da dialética, é "posicionada". Dela portanto náo derivam afirmaçōes que postulem essências. Nāo estamos, por exemplo, afirmando que "a saúde é...", ou que "o medicamento é...". Nossas afirmaçōes são sempre enunciadas, de um determinado ponto de vista: neste capítulo, o ponto de vista 60 do . produto.

Porisso, a saúde aparece como algo que o produto propicia e que faz parte dos seus atributos internos.

E obvio ,portanto, que a saúde e o medicamento tem outros sentidos possíveis, dependendo do seu sujeito institucional enunciador.

No caso do medicamento considerado em seu funcionamento social corrente temos, basicamente, três sujeitos institucionais enunciadores,ou tres pontos de vista : o ponto de vista do produto, o ponto de vista do . médico (e/ou farmacêutico, e/ou curandeiro) e o ponto de vista do paciente*

* O espaço social e psicossocial ocupado pelo paciente , inclui,além dele,outros atores sociais que com ele interagem como vizinhos, parentes, o amigo-que-tem-o-mesmo-problema-e-ficou-bom-com-omedicamento-x. 
Fora de seu funcionamento social corrente, o medicamento admite outros pontos de vista como por exemplo o que se desenvolve neste trabalho, e que $\epsilon$, na realidade, um meta-discurso ou meta ponto de vista, na medida em que, na qualidade de discurso academico, pretende analisar, refletir e mesmo re-construir os pontos de vista gerados no funcionamento social corrente do medicamento. 
1.2 - Medicamento como mercadoria simb6lica 


\section{SEMIÓTICA E REPRESENTAÇĀO.}

"Nos fenômenos, sejam eles quais forem - uma nesga de luz ou um teorema matemático, um lamento de dor ou uma ideia abstrata de ciência - a semiótica busca divisar e deslindar seu ser de linguagem, isto $E$, sua açāo de signo. Tão so e apenas. E isso ja é muito".

SANTAELLA,L. O que é semiótica. São Paulo, Brasiliense, 5a. ed., 1987 (pag. 11).

"E, eu falei pra ele (o vereador) isso aí Eu digo: quando vocês vão pra lá (na prefeitura) vocês vão com as ossas forças, com as nossas palavras. Foi nois que pediu pra você isso aí.

Então, invéz de você sê o nosso representante, . nois mesmo vamo se representa".

Dna. Maria. Pesquisa Participante. Itapecerica da Serra. Reuniāo da Pesquisa, 21/03/87. 


\subsection{1 - Medicamente come tecnologia.}

Antes de considerar, propriamente, o medicamento como * mercadoria simbólica, é necessário colocar a questão do medicamento como tecnologia ou produto tecnológico.

Isto tanto para marcar claramente que a posição adotada neste estudo não $\epsilon$, de nenhuma forma, anti-tecnológica, como para, de acordo com a perspectiva dialética, acentuar, até didaticamente, as especificidades (no caso do medicamento como mercadoria simbólica) utilizando o recurso do contraste, ou seja, tornar clara a tese através da exposição da antítese.

Assim, como afirmamos até aqui, nas sociedades capitalistas como a nossa, a saúde é sujeita a um processo de reificação, que se traduz . por uma hipertrofia de sua dimensão orgânica, sendo o medicamento um dos agentes deste processo de reificação.

Mas é preciso reiterar, mais uma vez, que, conforme a perspectiva teórica adotada, nāo fazemos colocaçōes essencialistas. O medicamento não é essencialmente reificador; ele funciona, nas sociedades capitalistas como a brasileira, também, como agente de um processo social e histórico de reificação da saúde.

Considerado em si, como tecnologia, é b́bvio que o medicamento deve ser visto como um produto da ciência, que representa um avanço . constante do homem no controle e prevenção das agressões exógenas e endógenas ao organismo, que afetam o seu equilíbrio. 
A dificuldade, quando se o considera como um avanço tecnológico, é separar as agressóes náo humanas e nåo voluntárias das agressóes geradas pela açăo do próprio homem frente a si mesmo e aos outros homens e frente à natureza.

Como produto tecnol6gico, em si, o medicamento, evidentemente, $\epsilon$ usado em ambas as situaçōes. Mas, no momento em que ele é objeto de reflexão pela Saúde Pública e pela Educação em Saúde Pública, é necessário entender e separar estas duas faces, sob pena de se estar confundindo prevenção, cura, ou alívio de situações mórbidas, com ocultamento de fatores causadores de doenças derivados da ação do homem.

\subsection{2 - A mercadoria medicamento e os seus sentidos.}

$\mathrm{O}$ que se está tentando neste trabalho é examinar as condições sociais mais gerais (ligadas à questão da mercadoria) e os mecanismos internos (a função simbólica) que determinam o funcionamento do medicamento como instrumento de um processo de reificaçāo da saúde, em curso no nosso país.

A mercadoria aparece socialmente como algo cujo sentido é o de "resolver" um estado "mau" (de necessidade), conduzindo a um estado "bom" (de satisfação).

Este é um dos sentidos da mercadoria.

Poderíamos dizer, em termos semióticos, na acepção de METZ (52), que o sentido acima, que representamos esquematicamente por EN - P ES, é uma das "mensagens" do "tema" mercadoria. 
A outra "mensagem" do tema mercadoria, o seu sentido latente, que contrapusemos ao primeiro, $\boldsymbol{e}$ a de que este sentido manifesto (expresso pela relaçăo : EN-P-ES) é a forma "naturalizada" e a-histórica sob a qual aparece, em formaçסes sociais capitalistas como a brasileira, a mercadoria; forma essa que permite obscurecer a hegemonia histórica da mercadoria na relação EN-P-ES.

Permanecendo no terreno da mensagem, mas colocando o medicamento como "tema", ao indagar-se sobre o seu sentido, a resposta do sistema é: o medicamento é um produto que existe para solucionar problemas ou necessidades de saúde.A resposta que expressa o que chamamos de sentido latente é: 0 . medicamento é, entre outras coisas, uma das múltiplas formas de que se reveste a hegemonia da mercadoria em formações sociais capitalistas como a brasileira.

\section{I.2.3 - Saúde se "escreve" medicamento}

Mas, segundo cremos, a semiótica permite desenvolver a idéia de que, na produção da semiose social, a mercadoria não é apenas provida de sentido, ou seja, mensagem. Ela tạbém é produtora de sentido, ou seja, símbolo.

A mercadoria não é apenas um objeto de sentido, mas também um sujeito de sentido; nāo apenas produto mas-considerada na qualidade de . símbolo-produtora de sentido.

Assim, quando se considera o medicamento como símbolo, à pergunta: o que é o medicamento, poder-se-ia responder: o medicamento (ao lado de outras mercadorias de saúde) é o modo como se "escreve" ou se "fala" a saúde", na e para a sociedade de consumo em que se vive atualmente; nesta 
sociedade, saúde se "escreve": "Saúde Bradesco", "Golden Cross", "cineangiocoronariografia", "Doril".

Com efeito, como afirma ECO (29): "As tendências atuais da semiologia tendem (...) a incluir entre os signos todos os aspectos da cultura e da vida social, inclusive os objetos (...). Vários estudiosos assentaram numa semiotica dos objetos da sociedade de consumo (Moles,1969; Baudrillard,1968). A arquitetura (cfr Eco,1968; De Fusco 1969; Koening,1970) é hoje estudada como um sistema de comunicações.

"Para uns, uma configuração (uma escada, uma porta) comunica a função que permite, e comunica-a também se a função não estiver explícita (se vejo uma porta fechada, decido não passar, em vez de experimentar darlhe com o nariz)" (pgs. 36, 37).

As ideias que desenvolveremos seguem pois a corrente dos que vêem a mercadoria não apenas como mensagem ou tema de mensagem mas também como ícone (na acepção de PIERCE $(58,59)$ ou símbolo (na acepção de TODOROF (76).

Produzir sentido é representar a realidade através de símbolos, o que implica, entre outras coisas, numa relaçāo simbólica, simbolizante/simbolizado, na acepção de TODOROF (76), e numa relação simbólica de substituição (algo que está por outra coisa) na acepção de $\operatorname{PIERCE}(58,59)$.

A reflexāo semiológica permite, com efeito, que se avance a ideia de que a mercadoria, nas sociedades capitalistas como a brasileira, aparece como um símbolo, que contém, como todo símbolo, uma face material (que, no caso dos medicamentos, é composta de grãos embalados, xaropes, etc.) cujo consumo (seja 
este, no caso dos medicamentos, deglut/çăo, absorçăo epidermica, injeçăo ou outras formas) permite a realizaçåo ou materializaçăo da qualidade abstrata ou sentido: a Sadude.

A mercadoria medicamento pode então ser hipoteticamente considerada, de acordo com a reflexăo semiológica, como um dos símbolos, ao lado de outros (45), de Saúde, em sociedades capitalistas como a brasileira. Ou, mais precisamente, o medicamento é um símbolizante que aparece como permitindo, ao ser consumido, a realização ou materialização de um simbolizado: a Saúde.

Em outro contexto de referência, BARROS (3), segundo cremos, está implicitamente colocando o medicamento como símbolo quando afirma: "Na transformaçāo da prática médica o medicamento ocupa posição relevante. Tornase fácil difundir a "venda da saúde" embalando-a em pequenos e práticos recipientes" (pag. 57, grifos nossos).

Parece-nos legítimo ir mais a fundo no pensamento expressado por BARROS, interpretando, em termos semióticos, a sua frase acima assinalada.

A embalagem da saúde em pequenos e práticos recipientes a que se refere a autora, pode, legitimamente, ser interpretada, em termos semioticos, como o processo de constituição do símbolo, que envolve, sempre, um recipinte (que, em termos semióticos, recebe o nome de simbolizante) e um conteúdo, que este simbolizante recebe e envolve (chamado simbolizado). 
O recipiente/simbolizante $\epsilon$, entåo, o próprio medicamento como coisa concreta, palatável, deglutivel, absorvivel epidermicamente, e o conteudo/simbo-lizado deste recipiente é a propria ideia de Saúde.

Difundir a venda da grande, ou abstrata, ou difícil ideia de Saúde, torna-se fácil na medida em que esta ideia transforma-se numa ideia prática ou pragmática através do processo de simbolização (e reificação), em que ela (a ideia de Saúde) aparece representada ou materializada no comprimido, ou gota, ou xarope.

Em síntese, podemos dizer que a autora coloca, em outras palavras, a idéia central deste trabalho, ou seja, que o medicamento é uma mercadoria simbólica. Com efeito, a saride é, para a autora, algo à venda; é, portanto, uma mercadoria. Esta "venda", por outro lado, é facilitada porque o medicamento é também um símbolo, ou seja, uma materialização de uma ideia, o que torna "prática" a sua venda.

A saúde, materializada através do símbolo medicamento, pode adquirir múltiplas facetas numa sociedade onde a mercadoria pontifica. A título de exemplo, (um entre muitos) vale mencionar o folheto da FONTOVIT (anexo). Através deste folheto pode-se verificar que, além da vitalidade e da potência sexual, pode-se, também, com o consumo das vitaminas FONTOVIT conseguir: $0^{*}$ bronzeamento, o fortalecimento dos cabelos e unhas, a mémoria, a digestão facilitada, a queima adequada das gorduras, a prevençāo dos resfriados.

\section{I.2.4 - Símbolo e consumo de símbolo}

Há que distinguir agora, no que se refere às mercadorias, símbolo e consumo do símbolo. 
A mercadorin sum aímbolo e, enquanto an, expressa e permile uma representagho da realldade.

Mas ela é também um objeto de consumo e, enquanto tal, implica em que esta representaçăo nấo é apenas produzida (pelos discursos da mercadoria) para ser entendida cognitivamente, mas também para ser vivenciada no momento do consumo.

A mercadoria aparece, no discurso elaborado sobre ela e para ela, como um simbolizante, uma coisa concreta, que representa, incorpora e materializa uma qualidade abstrata (que está associada a um valor: beleza, saúde, sensualidade, carinho, zelo maternal, etc.).

Mas o discurso da mercadoria nāo diz apenas "calça jeans é sensualidade", "Golden Cross é saúde em boa compania", "Vitassay é a vitamina dos campeōes de saúde". Ela não está apenas difundindo uma ideia, está também difundindo a possibilidade de efetivação desta ideia.

O símbolo "mercadoria" é sempre consumido mas não necessariamente (se bem que muito frequentemente) comunicado.

No caso da mercadoria medicamento podemos estar diante de símbolos que não estejam sendo usados, explicitamente (ou não estejam sendo apenas usados) como instrumentos para comunicar a ideia de Saúde, mas como • instrumentos para fazer com que seja consumida (e confirmada pelos resultados) uma determinada visāo da saúde (a da saúde reificada) .

Como sugere TEMPORĀO (74): "A possibilidade do consumo da droga, e na perspectiva da obtençăo de "resultados clínicos"concretos, 
seja "cura", seja supressâo de sinais e sintomas, vir a reforçar a assimilaçăo dos conteúdos (veiculados pela publicidade de medicamentos) nos parece ser uma hipótese interessante. Ou seja, no próprio momento do consumo o consumidor interiorizar a instancia social e suas normas" ( pag.170).

\section{Desenvolvendo a hipotese do autor, dirfamos que o}

sentido do medicamento não é apenas mentalmente consumido; ele é também orgânicamente experimentado, e uma coisa reforça a outra.

No momento em que se consome um símbolo como o medicamento está-se consumindo uma representação da saúde e, ao mesmo tempo, experimentando, na prática, as promessas imbutidas nessa representação.

\subsection{5 - O medicamente e a saúde como desejo consumido}

Quando se afirma que a saúde tem, na nossa e em outras sociedades, uma representação, um modo de expressão mercadologico que se traduz na existência de uma constelação de símbolos ou representames* de saúde, está-se querendo também dizer que a saúde é, em "estado bruto", um valor, um desejo** , na nossa cultura, que vem à tona, que se atualiza sob a forma de mercadorias que, em . razão disso, funcionam como representames de saúde.

\footnotetext{
- PIERCE(59) usa várias nomeclaturas para nomear os vários tipos de símbolos. O termo representamem nos parece adequado porque, evidentemente, evoca representação. $O$ representamem aparece então como a expressão concreta de um processo de representação. Afirma PIERCE (59): "Representar $\epsilon$ estar no lugar de, ou seja, estar em relação tal com outro que, para certos propósitos, algum espírito o tratará como se fosse aquele outro. Assim, um porta voz, um deputado, um advogado, agente, um diagrama, um sintoma, uma descrição, um conceito, uma premissa, um testemunho, todos representam algo diverso, sob variadas formas, para espíritos que os consideram sob este prisma. Quando se deseja distinguir entre aquilo que representa e o ato ou relação de representar, podemos dar ao primeiro o nome de "representamem" e ao âltimo o de "representação" (pag.ll4).

* A "saude" está presente em expressōes consagradas de "votos" em nossa cultura, como demonstra, entre outras, a expressão: "saáde e prosperidade".
} 
Estas representaços săo símbolos no sentido de que a saude e uma coisa "grande", "valiosa", um desejo, que e comprimido, sintetizado, num comprimido, acessivel, prático, fácil.

Os símbolos (a foice e o martelo, a cruz suática, a cruz de Cristo etc.) sempre comprimem uma "grandeza", um desejo, numa pequena superficie: assim se diz, por exemplo, que Marilyn Monroe foi um símbolo sexual, ou seja, alguém que concentra, em si, ou seja, numa mulher concreta, toda a "grandeza" da sexualidade e do erotismo femininos.

\section{I.2.6 - Medicamento e hóstia}

Visto agora o problema sob outro ângulo, pode-se comparar (e a comparação é quase obrigatória) o consumo simbólico do medicamento ao ritual católico da comunhão, em que o que comunga e consome a hóstia está consumindo uma representação do corpo de Cristo.

Esta representação é um simbolizante, um pedaço circular de pão ázimo, cujo significado (através da mediação do sacerdote que consagra o pão) é o corpo de Cristo e cujo resultado é a presença divina, naquele momento, no corpo do homem.

No momento simbólico do consumo de medicamentos o consumidor está, consciente ou inconscientemente, buscando uma materialização imediata equivalente (a "saúde imediata", da qual falamos alhures (45).

$\mathrm{E}$, vale notar que, também no caso do medicamento (e a comparação aqui, da mesma forma, se impōe naturalmente) há um "sacerdote" que "consagra" o medicamento. Com efeito, o ritual da" consagração" do medicamento - 
como um momento "dramático" da consulta médica - através da receita, năo deixa de ter paralelo com o ritual da consagraçăo da hostia - como um momento "dramático" da santa missa catolica.

O ritual católico da comunhăo pode ser visto como uma das formas de materializar a intangibilidade divina. E um dos momentos em que Deus - que é a suprema abstração - está presente no corpo do homem, pela concretização inerente ao processo simb6lico.

Da mesma forma, a saúde $\varepsilon$ também um conceito abstrato, um desejo, que necessita, portanto, na sociedade da mercadoria, assumir formas concretas, materiais, tangíveis, o que se faz através de processos de simbolizaçāo que permitem (através do medicamento, ou através do yogurte Bio da Danone, por exemplo), materializar o abstrato.

\section{I.2.7 - O medicamento como Icone Ouímico}

Quando perguntamos, na fase de pré-teste do instrumento de pesquisa, "como uma coisa tão pequena como um remédio pode resolver o problema de saúde das pessoas", obtivemos respostas que falavam:

a) "acho que tem muita química, né. A química está toda concentrada naquele comprimido..."

b) "eu entendo que o remédio vem suprir uma deficiência orgânica. $A$ doença, no meu entender, decorre justamente desta insuficiência. $E$ o remédio preenche, ou completa, ou substitui". 
c) "Ele deve conter, all dentro, ingredientes necessarios ou que estejam faltando no organismo, suprindo assim uma necessidade do organismo ou cortando o efelto de outras coisas que a gente tem em exagero no organismo ou que estejam fazendo mal".

Estas respostas sâo reveladoras de um certo grau de consciência a respeito de uma característica importante do medicamento, que permite avançar a ideia de que ele pode ser considerado um signo iconico ou ícone, na acepção de PIERCE (59).

Com efeito, define PIERCE ao ícone como: "um signo que se refere ao objeto ao qual denota meramente em virtude de caracteres que lhe são próprios (...). Qualquer coisa, seja o que for, qualidade, existente, ou lei é um ícone de alguma outra coisa, na medida em que é como esta coisa e que é usada como signo dela" (pag.30, destaques nossos).

Mais adiante apresenta PIERCE outra definição de icone. 'Um ícone $\varepsilon$ um Representamem cuja Qualidade Representativa $\varepsilon$ uma Primariedade dele como Primeiro. Isto é, uma qualidade que o f́cone possui como coisa o torna apto a ser um Representamem. Assim, qualquer coisa está apta para ser um Substituto (em itálicos no original) de outra coisa à qual é similar " (pag.46) (destaques nossos).

Desta forma, se considerarmos a saúde (reificada) puramente como estado orgânico, como realidade química, veremos que o medicamento contém, em si, este estado orgânico.

Em termos pierceanos, o medicamento é uma coisa 'química) como a saúde (reduzida à sua expressão química). Esta coisa química é 
usada como signo de saúde. A propaganda do medicamento Hepatoviz năo fala :"Hepatoviz 6 a saude do seu figado?"

Um medicamento como um sonffero pode ser visto como o signo icónico do sono enquanto entidade química. Um analgésico pode ser visto como o f́cone da năo -dor como química.

O sono, a não-dor, a potência sexual, a tranquilidade, a năo-pressāo alta, a năo-tosse, a năo-febre, existem em coisas externas ao organismo humano (e lembremo-nos da definição de mercadoria em MARX, in HORTON (39) que fala de uma coisa externa ).

Estas coisas, que são os medicamentos, são estados orgânicos ou mais precisamente, partes dele, fora do organismo. A pessoa que não dorme naturalmente, dorme com um medicamento; logo, o medicamento contém, numa certa medida, o sono na sua formula, ou a formula do sono. Ou dito de outro modo, o sonífero é o sono equacionado quimicamente; ou ainda, o sonífero é a expressão concreta da resolução tecnologica do sono.

O medicamento pode ser visto como um Representamem do sono fora do corpo na medida em que o sono, no organismo, é, também, uma entidade química.

De um modo geral, o medicamento é a fórmula (química) materializada do Estado de Bem Estar, ou seja, da Saúde. Mais precisamente, o medicamento é a fórmula (química) do Estado de Não-Mal Estar ou de Não-Agravo*

\footnotetext{
* Esta distinção entre estado de saúde e estado de não-doença é necessária, porque a produção da saúde não se dá apenas,como no caso da maioria dos medicamentos, em face de uma situação anterior de doença. Ela se dá também como reprodução de uma situação anterior de saúde: a mãe que amamenta seus filhos está, cada dia, reproduzindo um bebé saudável. É o caso também dos medicamentos usados preventivamente.
} 
Podemos dizer que os medicamentos sấo imitaçoes 1 vida enquanto fato organico, pedaços de vida organica (sono, tranquilidade, potênc sexual, etc.) comprimidos num comprimido ou numa gota ou num xarope.

Os medicamentos podem ser vistos entáo como $\mathrm{I}^{\prime}$ criações da vida pelo homem.Todos os medicamentos são, de certo modo, "ṕlulas d vida", como as antigas "Pflulas de vida do Dr. Ross".

Enquanto ícones, os medicamentos aparecem com produtos simbólicos da mesma natureza do coração artificial, do rim artificial, da lentes de contato.

A diferença é que, num caso, eles aparecem comı reconstrução da vida como física e, no outro caso, como química. Vejamos un exemplo na reportagem de capa da Revista Veja (77): "Um golpe da ciência na rai da dor". Afirma a reportagem :

"Há duas décadas os médicos sabem que a flutuação nos níveis de serotonina, um mensageiro químico cerebral, torna os indivíduos mais sensíveis às dores. Na semana passada, o laboratório britânico Glaxo anunciou o início de testes com voluntários de uma nova droga batizada ainda com o número de código GR 43175 e que tem a capacidade de suprir serotonina sintética, que é percebida instantaneamente pelo tálamo. A vantagem da droga da Glaxo é que ela só se manifesta quando há falta de serotonina natural, funcionando como um eficiente controlador da concentração da substância no humor cerebral. Ela deve estar à venda apenas em 1991" (pag.66) (destaques nossos). 
Assim, nos termos de PIERCE (59), de acordo com Revista Veja, a serotonina sintética, "está apta para ser substituta de outra coisa (a serotonina natural que falta) a qual é similar".

Nesta medida, este medicamento pode funcionar como Ícone da Saúde, no caso, da năo-dor de cabeça crônica.

Neste caso (e em casos similares) o medicamento pode ser visto como prótese química. Vejamos um caso similiar. 


\section{0 desequilíbrio desses fatores pode levar à doença péptica ulcerosa.}
A forma eficaz de se tratar a doença péptica ulcerosa é restaurar os níveis das prostaglandinas.

\section{propriedade comprovada das prostaglandinas.}



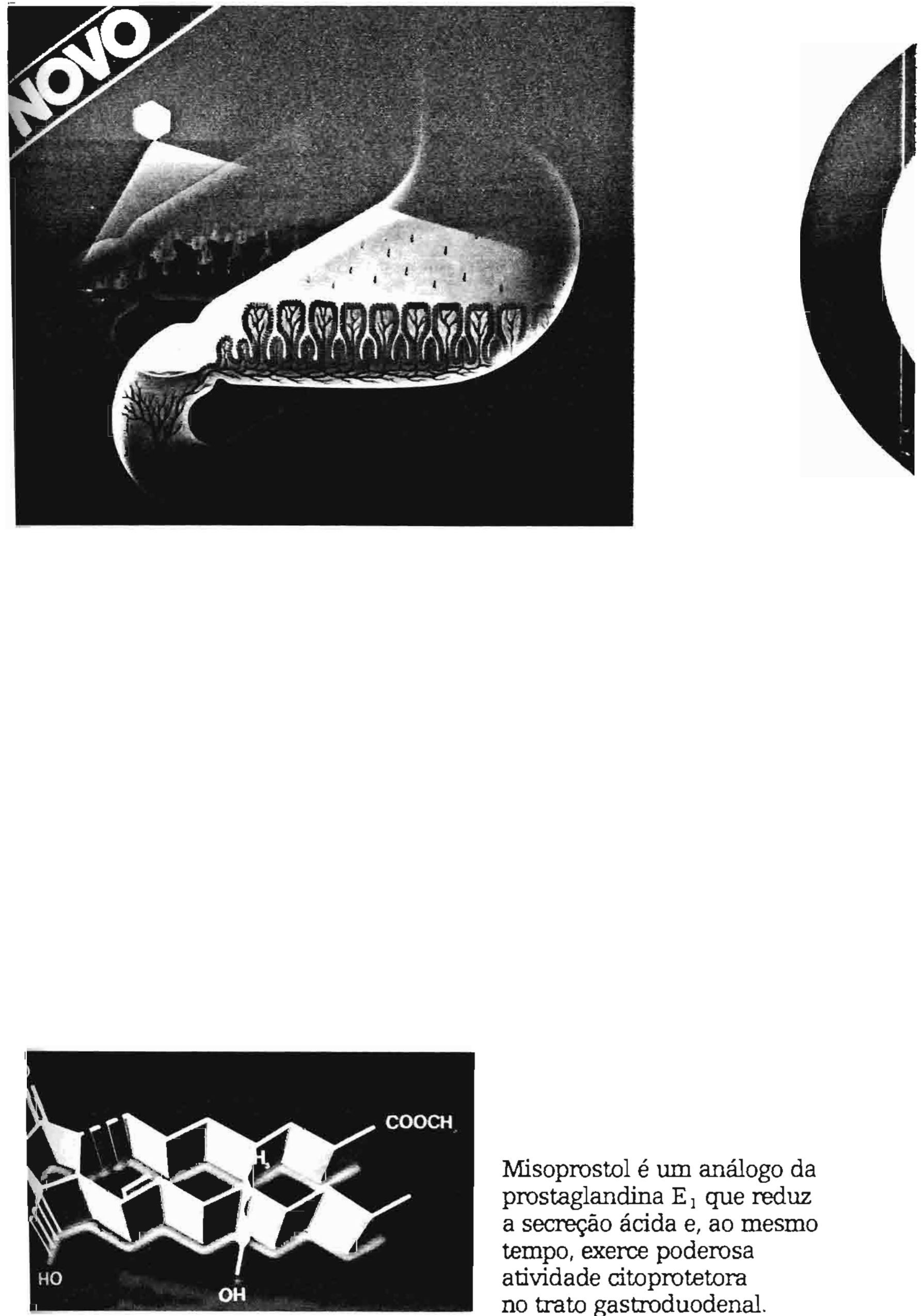

Misoprostol é um análogo da prostaglandina $\mathrm{E}_{1}$ que reduz a secreção ácida e, ao mesmo tempo, exerce poderosa atividade citoprotetora no trato gastroduodenal. 


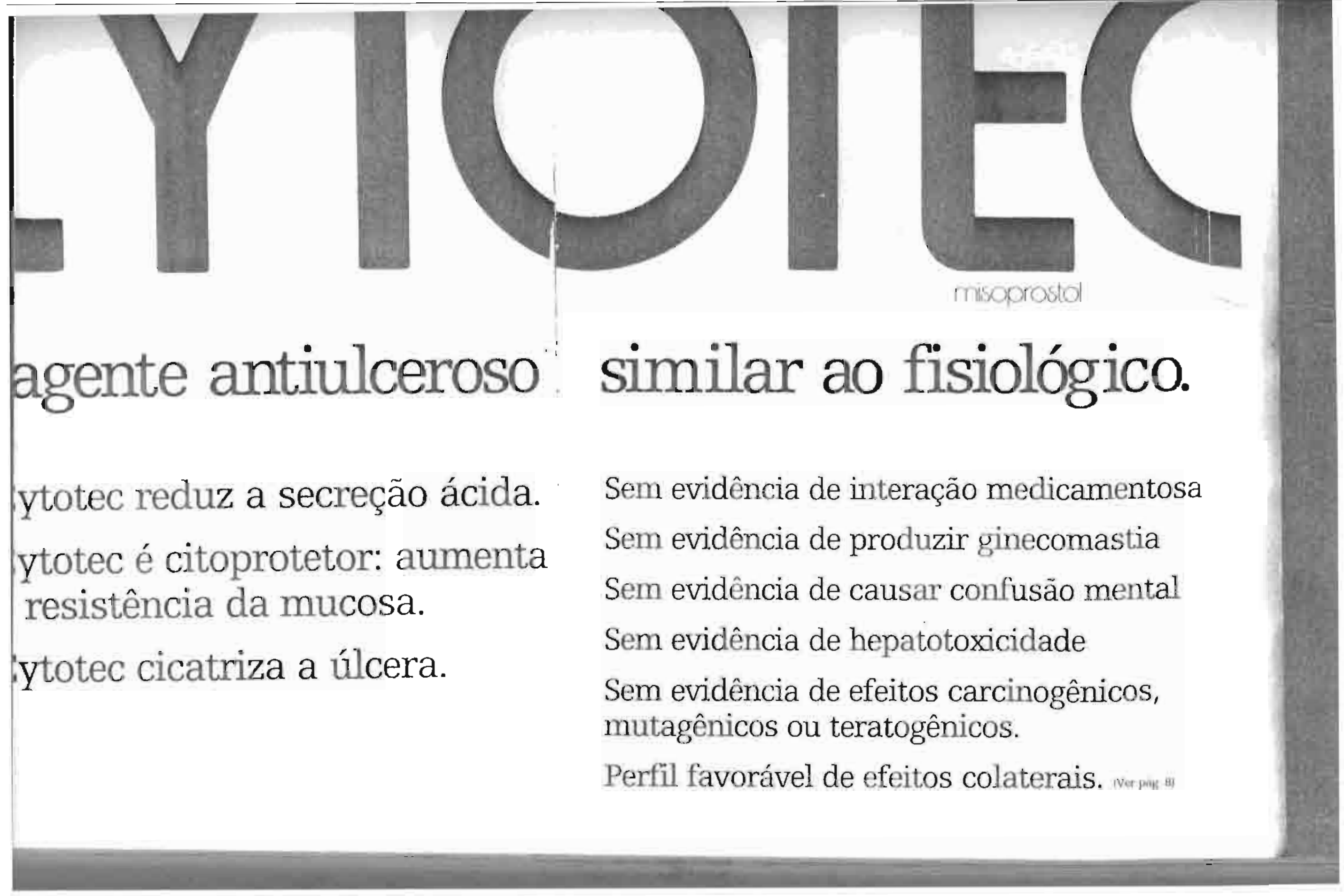




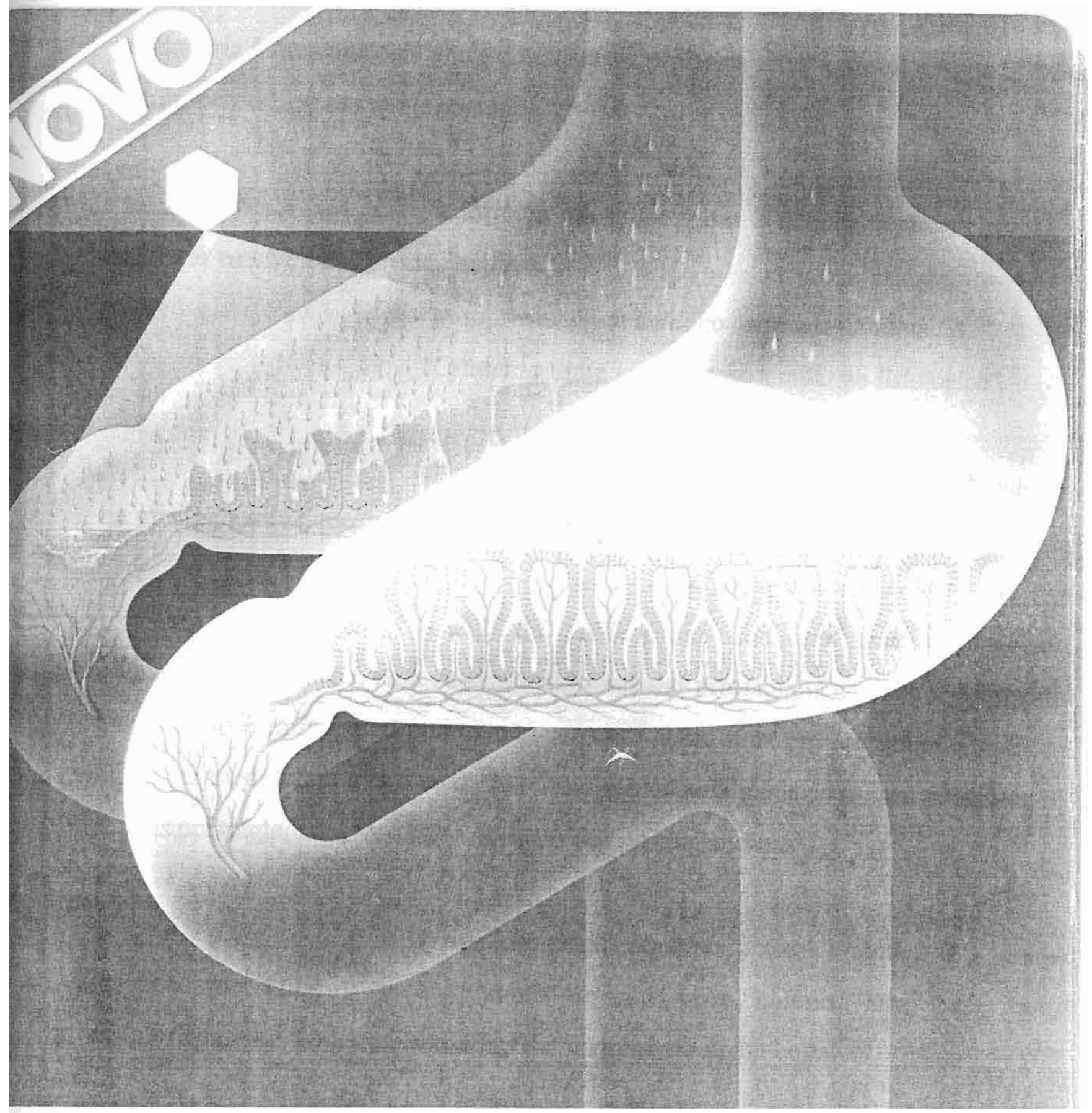

\footnotetext{
Criado pela Natureza, aperfeiçoado pela pesquisa Searle.
} 
Fica claro que o sentido central do texto da peça publicitária é uma analogia entre o natural (a prostaglandina natural) e a sua prótese (o misoprostal, ou seu nome comercial):

"a formula eficaz de tratar a doença peptica ulcerosa é restaurar os níveis das prostaglandinas."

"misoprostal é um análogo da prostaglandina E1..."

"Cytotec: agente antiulceroso similar ao fisiologico".

O medicamento (misoprostal) é um "similar", "análogo" da prostaglandina que, portanto, se assemelha a esta prostaglandina.

A ideia da" saúde como não-úlcera" tem sua expressão química, no organismo, num determinado nivel das prostaglandinas. O medicamento que contém o misoprostal pode então ser visto como uma prótese química da nãoúlcera na medida em que o medicamento é capaz, pela analogia do seu componente com as prostagladinas, "restaurar os níveis das prostaglandinas".

$O$ medicamento enquanto prótese química $\varepsilon$ a parte química que falta, o preenchimento de um vazio químico, um ícone que, metaforicamente, poderíamos chamar de "membro ou órgão químico".

Na representação visual, que tem por título: "Criado pela natureza, aperfeiçoado pela pesquisa Searle", ve-se um par de estômagos/duodenos (o "original, criado pela natureza" e a réplica, "aperfeiçoada pela pela pesquisa Searle").

A figura permite avançar a ideia de que, do medicamento (no canto esquerdo folha) emana, ou que ele "da luz" a um novo (cuja representação 
gráfica aparece no angulo superior esquerdo da folha) estomago/duodeno, um estomago/duodeno aperfeiçoado.

Há na peça publicitária um jogo de contrastes visuais, no . que se refere aos pares de estomagos/duodenos, entre "velho e o novo", "claro e escuro", "alegre/triste", "regular/irregular", "doente/sa-dio", que eståo presentes para subsidiar e corroborar visualmente a oposição: "criado (pela natureza) e aperfeiçoado (pela pesquisa Searle)".

O medicamento contém, em si, um novo "estômago/duodeno" (aperfeiçoado pela pesquisa da Searle); o medicamento irradia, ilumina, projeta o original e a réplica aperfeiçoada como a significar , a ex-pressar (por para fora) através da representação visual, a própria ideia de "estômago/duodeno aperfeiçoado" (por contraste visual com o "original") imbutida no medicamento e não visível a olho nu.

\section{I.2.8 - O Icone Ampliado}

A noção de f́cone aplicada à area da saúde permite explorar zonas de sentido associadas às relações atuais e futuras do homem com a ciência e com os produtos da ciência do funcionamento do organismo como máquina.

A própria noção de "máquina humana" $\varepsilon$ icônica (não se trata,portanto, de uma metáfora) na medida em que o ser humano $\varepsilon$ visto e tratado a semelhança* de (ou mais precisamente, como se efetivamente fosse) uma máquina.

- Afirma PIERCE (59 :"Ocorre simplesmente que as suas (do ícone)qualidades fazem lemnbrar as daquele objeto e despertam no espirito, sensações análogas àquilo que parecem" (pag129). 
Sáo tambem lcones os aparatos como tombgrafos, estetoscópios, etc. que, na qualidade de extensoes dos sentidos humanos, permitem ver e ouvir cada vez mais e melhor, o corpo humano.

Símbolos do "homo sapiens" contemporaneo, herois dos tempos modernos que, em sua versáo infantil, presente nos desenhos animados da televisão, adquirem a forma completa de um robô, que incorpora em seu organismo/máquina estas extensōes tecnológicas dos sentidos humanos.

Mais genericamente, a ciência tecnológica do corpo humano é vista socialmente como a inevitável forma contemporânea de "estar no mundo"* como um avanço constante no entendimento da maquinária humana e na consequente produção e aproveitamento de ícones do ser humano, ou seja, "peças de reposição" (próteses físicas ou químicas, transplantes) sempre que as "peças originais" apresentarem defeitos.

Observermos a respeito, a peça publicitária do medicamento ILOBAN.

- Afirma WOLPE (82); "In the social realm, technology has replaced ritual as the representation of our relantionship to the material world. We create technolgies as our way of relating to the outside world... "(destaques nossos,pag.320). 

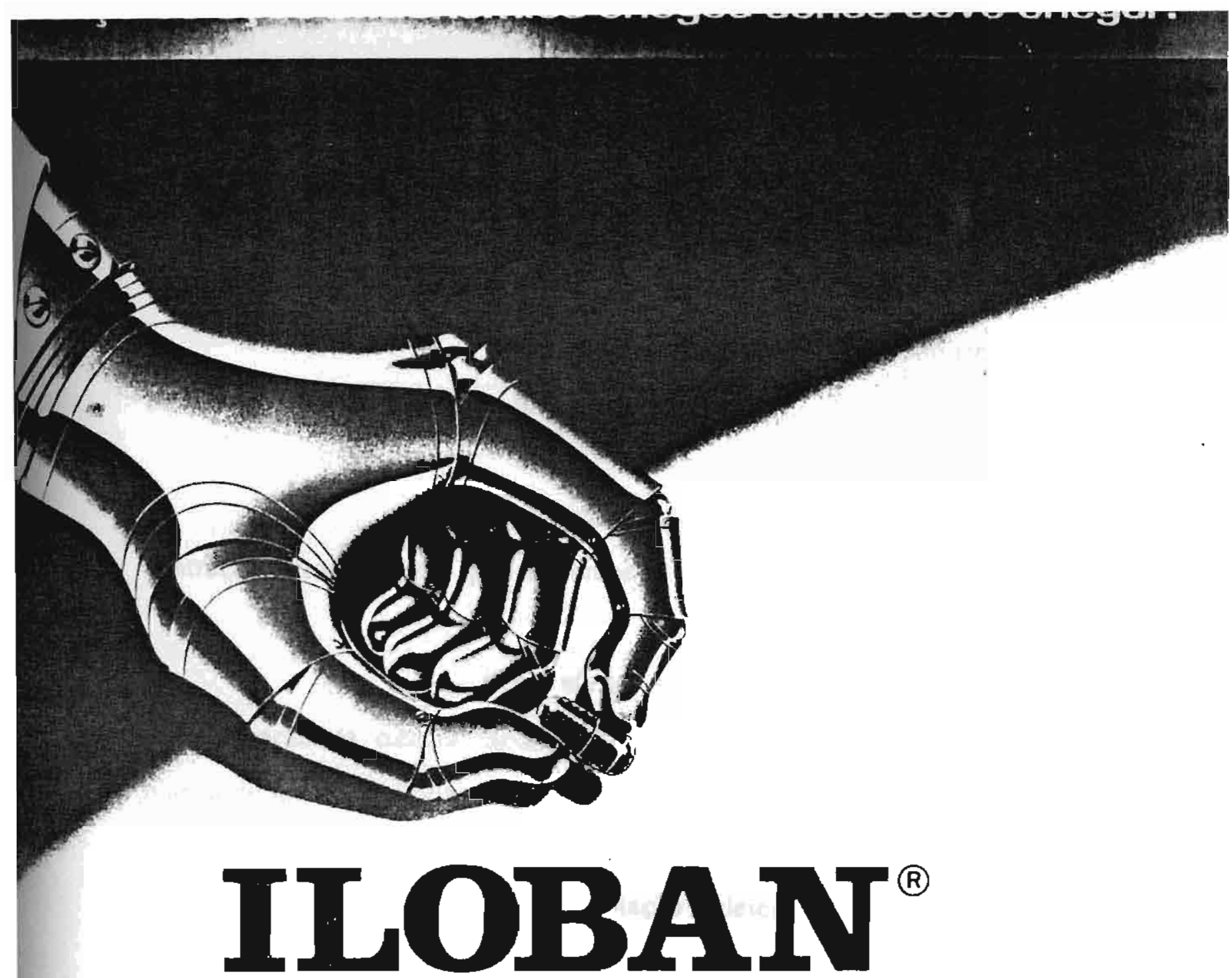

O hematínico programado.

Maior eficácia antianêmica náxima tolerância gastrintestinal.

\section{matínico programado}

ragrénulos de lloban cápsulas epresentam uma ura gastrorresistente que permite a integridade do ate o duodeno. locel físiologico de sue maior เ̇o.

\section{açào seletiva}

ais componentes de lloban, ácido fólico. vitemine ítamine C éa liberados no estómego, respeitando umatros flaiológicos e enatómicos de abśorçâo.

mo de tolerância

rogrénuloe oferecem maior superflcie de conteto issoluçèo, evitendo preticemente a constipsçáo al (fator freqüente nas gestantes).

\section{OBAN ${ }^{\circledR}$ o hematinico programado.}

Melhor aproveitamento

Cada microgránulo se comporta corno ume unidade ferma. ceutice únice. cuje coberture especial essegura liberaçá do aeu principio ativo no local flsiológico ideal para sua melhor absorçóo.

\section{Nunca o ferro foi tāo longe.}

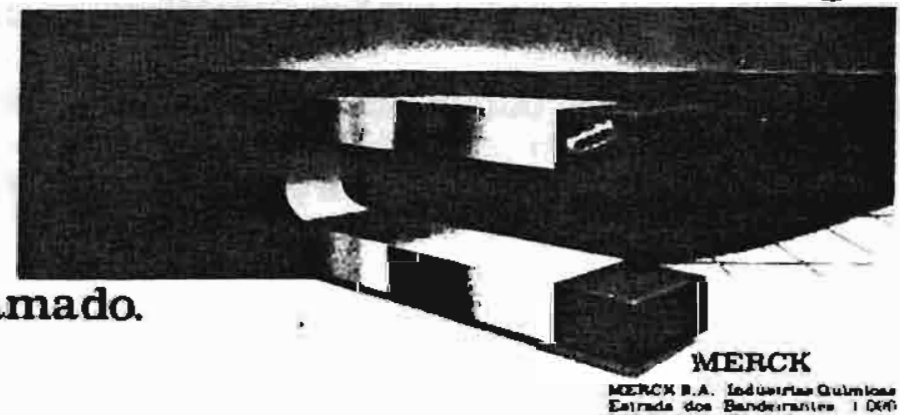

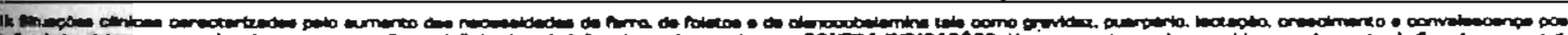

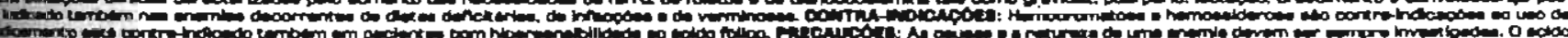

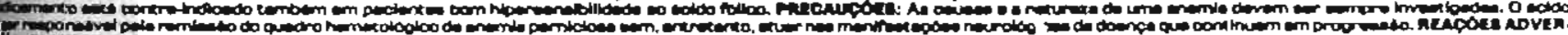

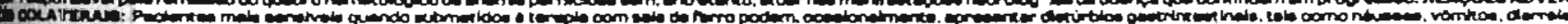

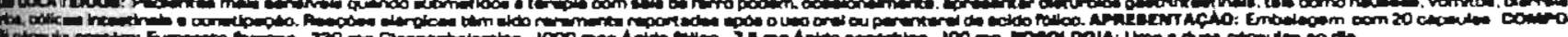

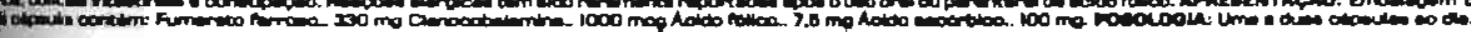


Dela ressalta, na parte verbal, de modo ostensivo, a ideia de ciencia contemporânea como avanço cientiffico:

"O avanço da açăo antianemica chegou onde deve chegar".

"O hematínico programado" (repetido tres vezes no texto, duas na qualidade de atributo intrínseco do produto).

A representação visual central $e$, por sua vez, uma ilustração clara das ideias que acabamos de colocar.

Com efeito, o que $\varepsilon$ esta figura central senão uma representação da ciência médica (simbolizada pelo pedaço de tecido branco da manga do jaleco) "robotizada", no sentido positivo do termo, onde a robotização está associada, como denotação, à ideia de ferro (a mão é de ferro, da mesma cor que o imã, representado abaixo) e como conotação à ideia de avanço científico?

O medicamento, quanto a ele, é "programado" (termo que, evidentemente, conota "avanço", "exatidão", ligado que está à informática) para chegar íntegro até o duodeno,. "local fisiológico de maior absorção", ou seja, para desempenhar, da melhor maneira, o seu papel no funcionamento da máquina ou do "hardware" humano.

Em síntese, nesta peça publicitária, o essencial do texto verbal e da imagem permite avançar a idéia de que o seu sentido central postula uma relação icônica entre a máquina propriamente dita e a máquina humana. 


\section{VOLTA ȦS COISAS NATURAIS}

"Cremos haver cumprido assim uma tarefa séria contribuindo para o bem estar, a saúde, a longevidade e a beleza de quantos- homens $e$ mulheres - optam pela cosmética de preparados simples e eficazes nesta volta cada vez maior aos encantos e beneficios das coisas naturais"

CHITWOOD, S. - Cosmética Natural,3a ed. São Paulo, Ground, 1987 (pag.12). 
1.2.9 - Um interpretante de iconeiresolucho tecnolódca da vida $X$ resolucáo natural de vida

Os medicamentos sâo efetivamente lcones ou representames da saúde "quimificada" (que, por sua vez, c um representamem da saúde "tout-court") na medida em que, em termos pierceanos, săo imitações desta coisa e signos dela.

Os medicamentos sẫo representaçōes, símbolos de saúde, que ademais de se apresentarem como tais (como se disessem: "eu sou Doril, o sumiço da dor, consuma-me") dāo margem ao surgimento de uma outra ideia, ou significado, ou interpretante*, que poderıamos chamar de "Resolução Tecnológica da Vida". Ou seja, os medicamentos como símbolos, além de diserem: "eu sou a saúde, consuma-me", disem: "eu sou a saúde como resoluçăo tecnologica da vida, consumame".

É esta "resolução tecnológica da vida" (e não a "saúde") que se defronta, como sentido, com a "resolução natural da vida", no mercado simb6lico da saúde, ou, mais precisamente, na dimensāo simbólica do mercado de bens de consumo de saude.

A "resolução natural da vida" é o significado associado,ou interpretante da "saáde natural" (materializada nos produtos naturais), também à venda no mercado de bens de consumo de saúde.

- Coloca PIERCE (59): "Um signo, ou representamem (em itálicos no original) 6 algo que, sob certo aspecto ou de algum modo, representa alguma coisa para alguem. Dirige-se a alguém, isto $C$, cria na mente desta pessoa um signo equivalente ou talvez um signo melhor desenvolvido. Ao signo assim criado denomino interpretante(em itálicos no original) do primeiro signo" (pag.94) . 
A "resoluçăo tecnologogica da vida" e à "resoluçấo natural da vida", correspondem, por sua vez, uma serie de interpretantes, que podemos colocar, respectivamente, sob a forma de pares de oposiçáo como:

- moderno/antigo

- artificial/natural

- concentrado/disperso

- forte/fraco

- rápido/lento

A título de exemplo (da oposição: "rápido/lento" :: "artificial/natural"), vale mencionar uma peça publicitária de televisão (1988) de uma medicação homeopática*. Na primeira cena mostra-se uma jovem tomando um remédio homeopático. Em seguida a jovem diz algo ao telespectador como: "não fique aí me olhando, ninguém emagrece em quinze segundos não".

Vejamos outro exemplo:

"A rigor, a homeopatia pertence a categoria dos produtos "alternativos" mas, na prática, produtos naturais e produtos alternativos são a mesma coisa. A propósito, uma das mais importantes lojas de produtos naturais em São Paulo chama-se justamente "Alternativa". 


\section{A suplementação natural de fibras dietéticas.}

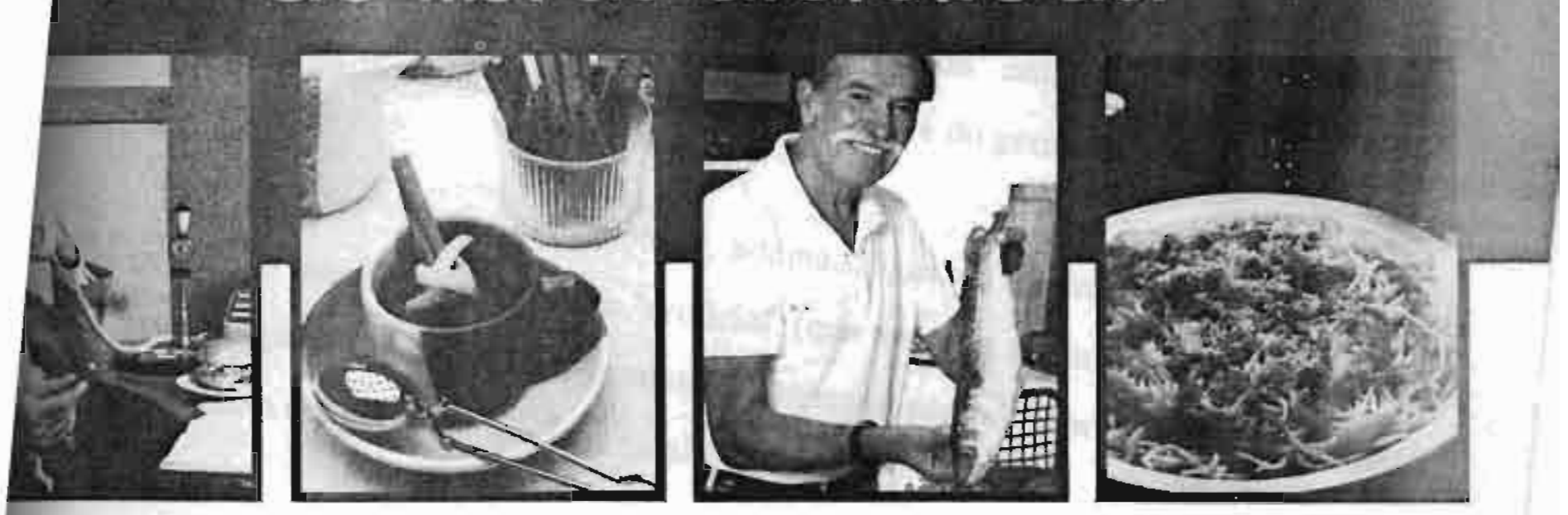

plementa a dieta alimentar pore em fibras.

umenta o volume fecal e molece as fezes.

stimula de forma fisiológica funçāo intestinal.

ço provoca cólicas, diarréia gases.

oporciona evacuaçōes javes e livres de esforço.

xcilita a adesāo e

ontinuidade do tratamento, ela possibilidade de alternar ubores e modos de preparo.

ose diăria: Em geral. 1 a 2 redidas ( 15 a $30 \mathrm{~g}$ ). ou a itério médico.

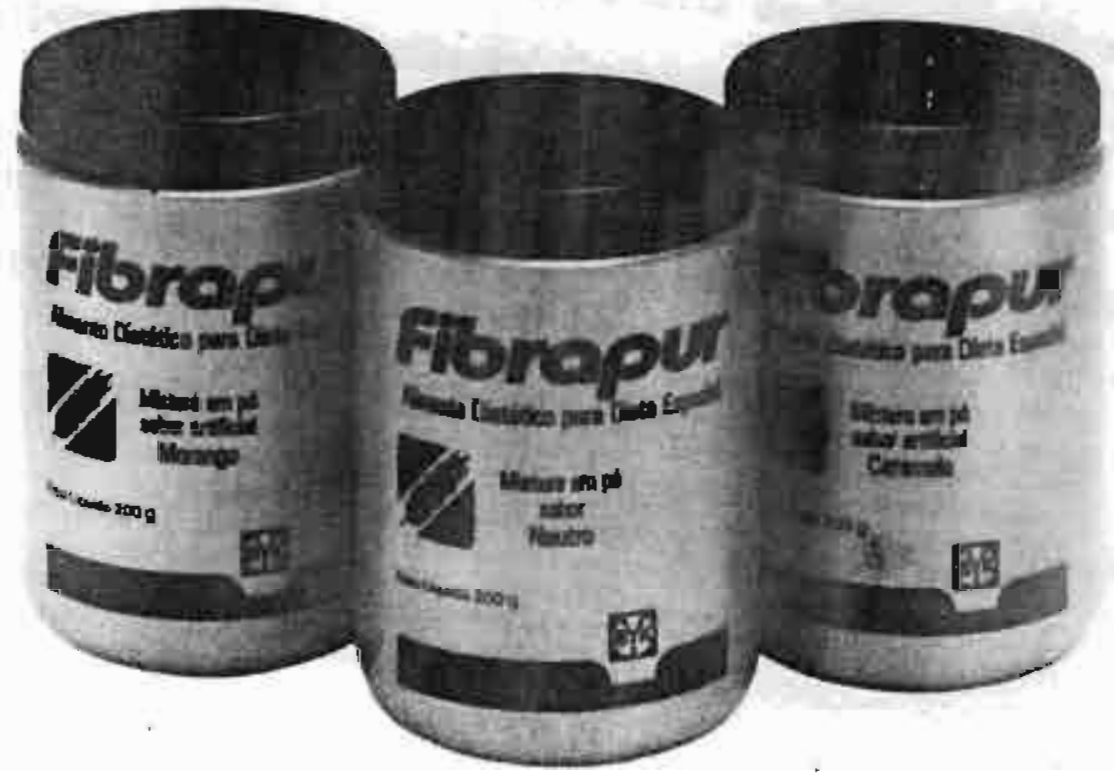

- Concentrado obtido selefivamente da parte nobre do germe de trigo.

- Sabores: caramelo, morango e neutro. 
Vê-se claramente, a presença da ideia de "natural": "A suplementaçăo natural de fibras dietéticas" e da ideia de "concentrado" (ligada a "resoluçăo tecnologica da vida"): "concentrado natural de fibras dietéticas"; "concentrado obtido seletivamente da parte nobre do germe de trigo" .

Note-se, ademais, que em nenhum espaço do "corpo do texto" $\varepsilon$ mencionada a ideia de "artificial" (que aparece, muito discretamente, no texto da propria embalagem do produto*): "mistura em po, sabor artificial morango"; "mistura em pó, sabor artificial caramelo".

Evidentemente, a palavra "artificial" tem conotação pejorativa, e, porisso, se a esconde. Com efeito, em dois momentos, no corpo do texto, usa-se "sabor" mas em nenhum deles há a menção a sabor "artificial".

Destaca-se, por sua vez, a ideia de "concentrado", de modo que ela acaba representando a "conciliação" ("concentrado natural") entre a . "resolução tecnológica da vida" e a "resoluçāo natural da vida": com efeito, a tecnologia permite "recuperar" (para a "Ciência") a natureza na sua parte mais nobre: "concentrado obtido seletivamente da parte mais nobre do germe de trigo".

\footnotetext{
* o que mostra que a ideia não pertence ao discurso mas a seu referente, ou mais precisamente, à parte verbal deste referente.
} 


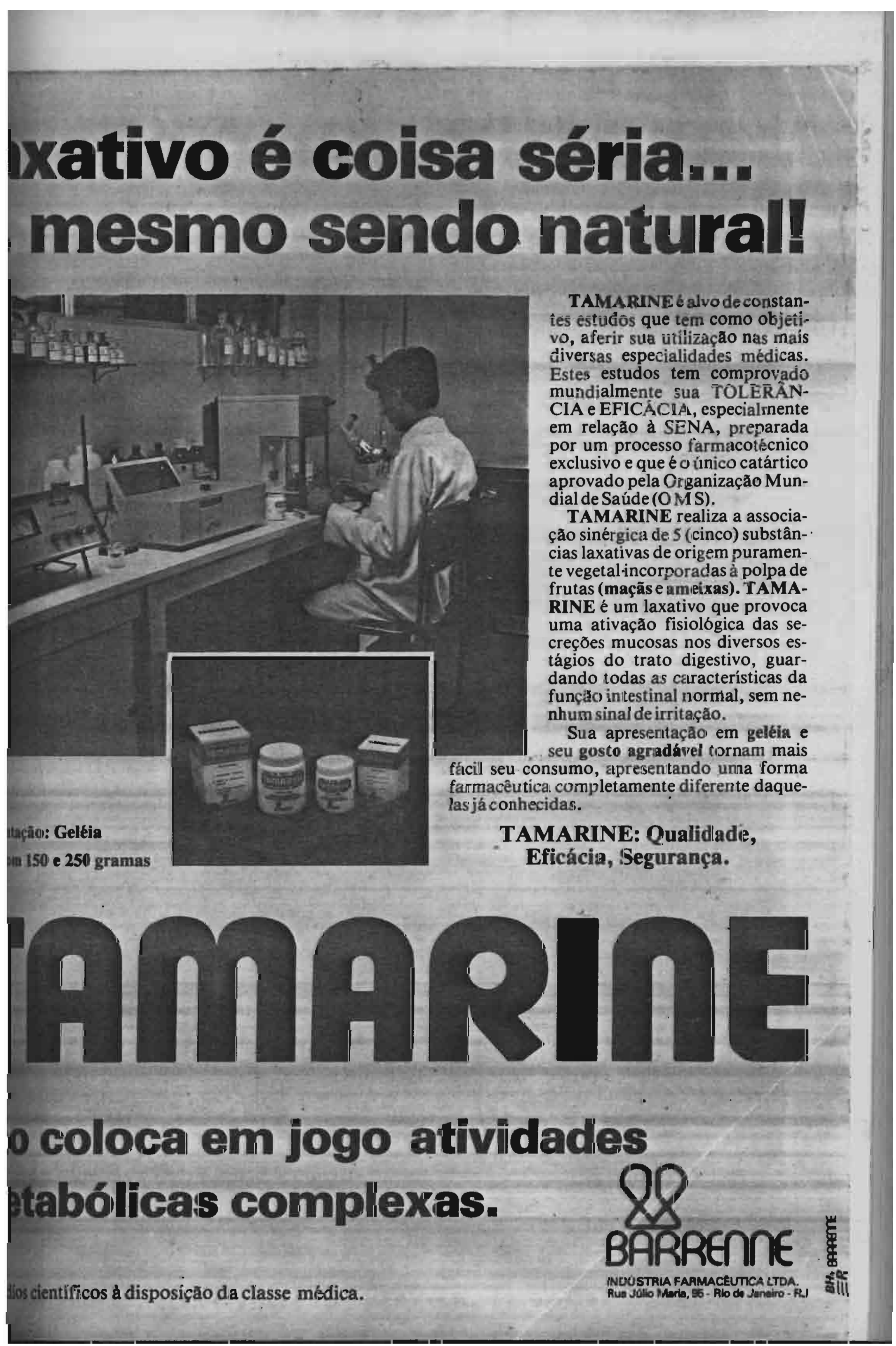


Esta outra peça $\in$ tambem um exemplo de conciliaçăo entre a "resolução tecnologica da vida" e a "resoluçăo natural da vida".

Do "natural", o medicamento, segundo a peça publicitária, aproveita apenas o essencial: a propria ideia de "naturalidade",ou seja, de vinculo com a natureza, significada visualmente pelas folhas expalhadas em volta do medicamento e pela cor verde que envolve o nome do medicamento.

Ao caráter "natural" do medicamento é agregado o componente científico, que o torna, além de natural, "sério" ("Laxativo é coisa séria... mesmo sendo natural").

Este componente "cientifico" é significado pela mensagem verbal ("alvo de constantes estudos", etc.) e pela mensagem visual central, do tecnico de laboratório e da aparelhagem, que denotam, claramente, "cientificidade" ou seja, "seriedade". 


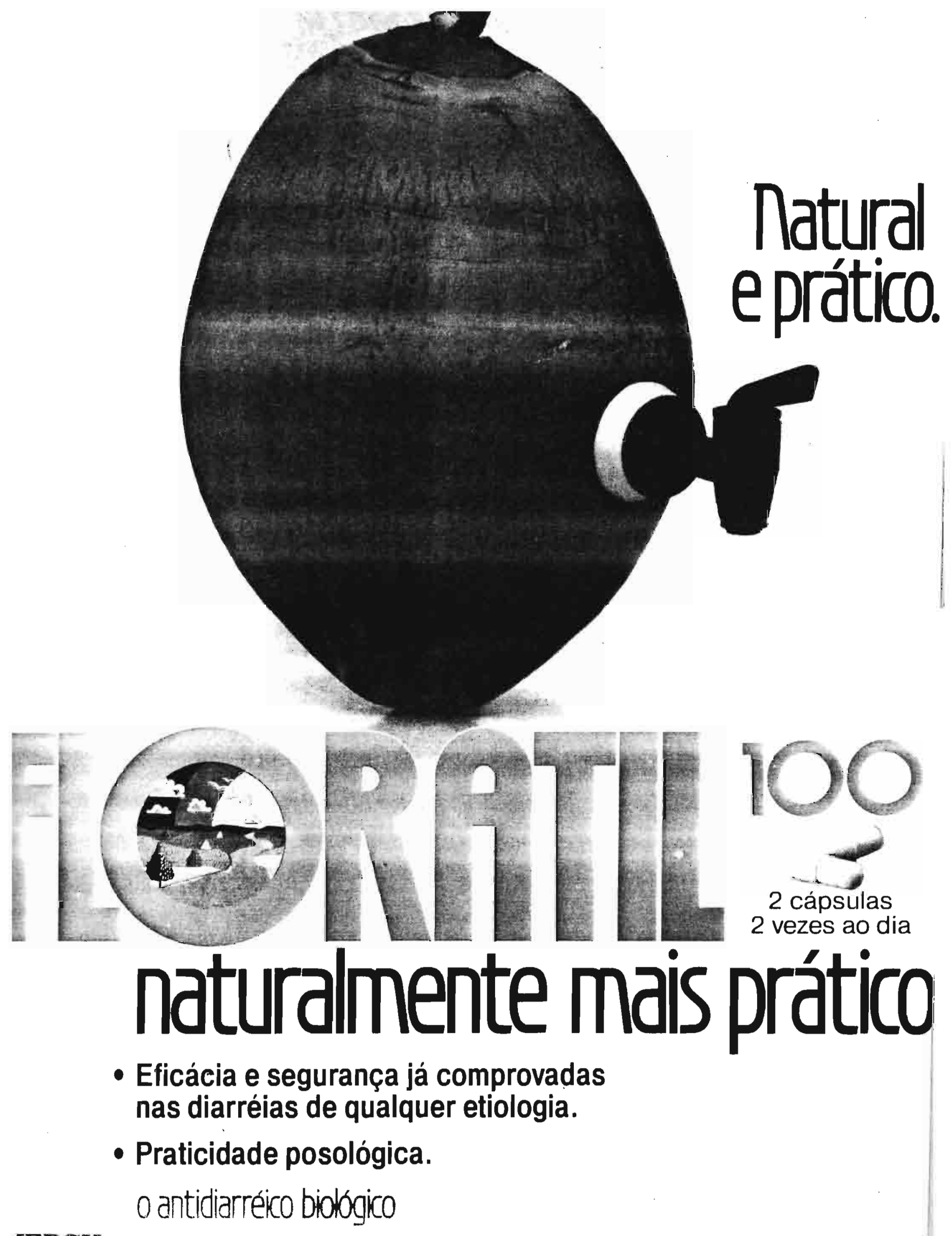

Posologia: Nas diarreias agudas: 2 cápulas. 2 vezes ao dia. Nas diar réias crónicas: 1 cápsula, 2 vezes ao dia Composição: Sua composiçảo totalment natural assegura uma terapéutica isenta de qualquer efeito colateral. Cada capsula contem; Saccharomyces boulardii 17-liofilizado 100mg. Indicaçóes Diarreias infecciosas. inespecificas, alimentares e na profilaxia e terapeutica da diarréia provocada pelo uso de antibióticos equimioterapicos. Aprese! tação: Embalagem com 12 cápulas. Contra-Indicaçóes: Nào tem. Efeltos Colaterais: Náo tem. 
Da mesma forma, esta outra peça indica a presença verbal da "resoluçåo natural da vida": "natural e prático"; "naturalmente mais prático"; . "o antl diarreico biológico" e a sua presença visual no coco e na paisagem desenhada dentro da letra "O".

Vale notar que nas publicidades de medicamento encontra-se com frequência, associados ao medicamento, termos como " biológico" e "fisiologico" que, desta forma, atestam a existência, no plano do simbólico, destes "biológico " e do "fisilogíco " fora do organismo. Isto mostra claramente a ideia que se quer passar, de um vínculo icónico da mercadoria medicamento com o organismo, ou seja, como o biológico e fisiológico propriamente ditos.

O medicamento natural/biológico/fisiológico é a reprodução (obra necessária da tecnologia) do natural numa mercadoria.

Esta conciliação entre a "resoluçāo tecnológica da vida" e a "resolução natural da vida", apresentada nestes exemplos, expressa uma necessidade da dimensão simbólica do mercado de bens de consumo de saúde: a de dar conta de uma reação de uma parcela de.consumidores de medicamentos (alopáticos) que vêem-influenciados pela pensamento ecológico- nestes, um exemplo do "artificialismo" da vida moderna e das suas consequências "nefastas" no que há de mais central no ser humano: seu próprio organismo.

\section{I.2.10 - Eficiência e eficácia como fatos simbolicos.}

A saúde está concretamente naquele comprimido ou naquela gota. Ele, ou ela sāo a saúde, representam a saúde. 
Mas se trata de um simbolo especial. Como a hóstia, o medicamento é um símbolo a ser consumido pela boca, a ser in-corporado.

Além disso (e diferentemente da hóstia) a presença da saúde no medicamento é um fato atestável empiricamente. Porisso, o medicamento aparece como um símbolo eficaz (ou potencialmente eficaz) isto $\epsilon$, capaz de cumprir o que promete.

E nāo simplesmente eficaz, mas também eficiente ( $€$ o interpretante" resoluçāo tecnologica da vida" com seu subintepretante:"rápido/lento").O medicamento (em alguns casos) não anuncia apenas: "eu sou a saúde, prove-me" (eficácia simbblica). Ele afirma ademais: "eu sou a saúde já, prove-me" (eficiência simbólica).

Em termos simbólicos, a eficiência é a possibilidade de realizaçāo quase imediata de um desejo: como o mago da lâmpada de Aladim, que dá nascimento aos desejos com o simples esfregar do pano na lâmpada, "Tomou Doril, a dor sumiu".

Com efeito, analisemos brevemente a frase: "Tomou Doril, a dor sumiu".

A idéia fundamental nela contida refere-se ao tempo (ou seja, à eficiência): "Tomou Doril (ato contínuo) a dor sumiu".

Mas se trata, se observarmos bem, de um tempo muito especial. Com efeito, na frase, o ato concreto de tomar Doril produz o efeito ( o "sumiço da dor") como sua consequiência lógica e não cronológica; esta relação liga • 
um antecedente logico e sintático (Tomou Doril) a um consequlente logico e sintático (a dor sumiu).

Não se trata de uma distancia temporal qualquer (mesmo mínima) entre $o$ antecedente e o consequente. Trata-se de uma distancia temporal zero: não decorre nenhum tempo físico entre $o$ ato de tomar Doril e a dor sumir; o sumiço da dor está implicado no ato de tomar Doril.

Esta relação lógica aparece contudo, no universo do . simbólico, como a expressāo mesma da quintessência da rapidez. Como se houvesse um "plim" (símbolo auditivo do efeito mágico) entre "Tomou Doril" e "a dor sumiu".

Com efeito, está implícita na frase a ideia de um tempo mágico, de um "instantâneo de fantasia": o mero contato de Doril com o corpo produz o sumiço da dor. E como se em vez de "Tomou Doril" estivesse sendo dito "Tocou Doril": tocou Doril (no corpo) a dor sumiu.

O toque de Doril no corpo recupera, portanto, plenamente, o mito da varinha de condão: não apenas produz o que se deseja, instantaneamente, como o produz (da mesma forma que o faz a varinha). radicalmente: a dor, com o toque de Doril, nāo "se esvai", não "se extingue", gradualmente: ela some, o que é a eficácia máxima.

Doril signficia pois o sumiço da dor (eficácia), em qualquer farmácia - ou mesmo bar -(acessibilidade), ao simples contato com o corpo (eficiência). Ou seja, a saúde como mito típico de sociedades de consumo como a nossa, encontra-se plenamente representada ou simbolizada neste comprimido.

\section{I.2.11 - A ideia de eficiência e rapidez: ilustraçōes.}




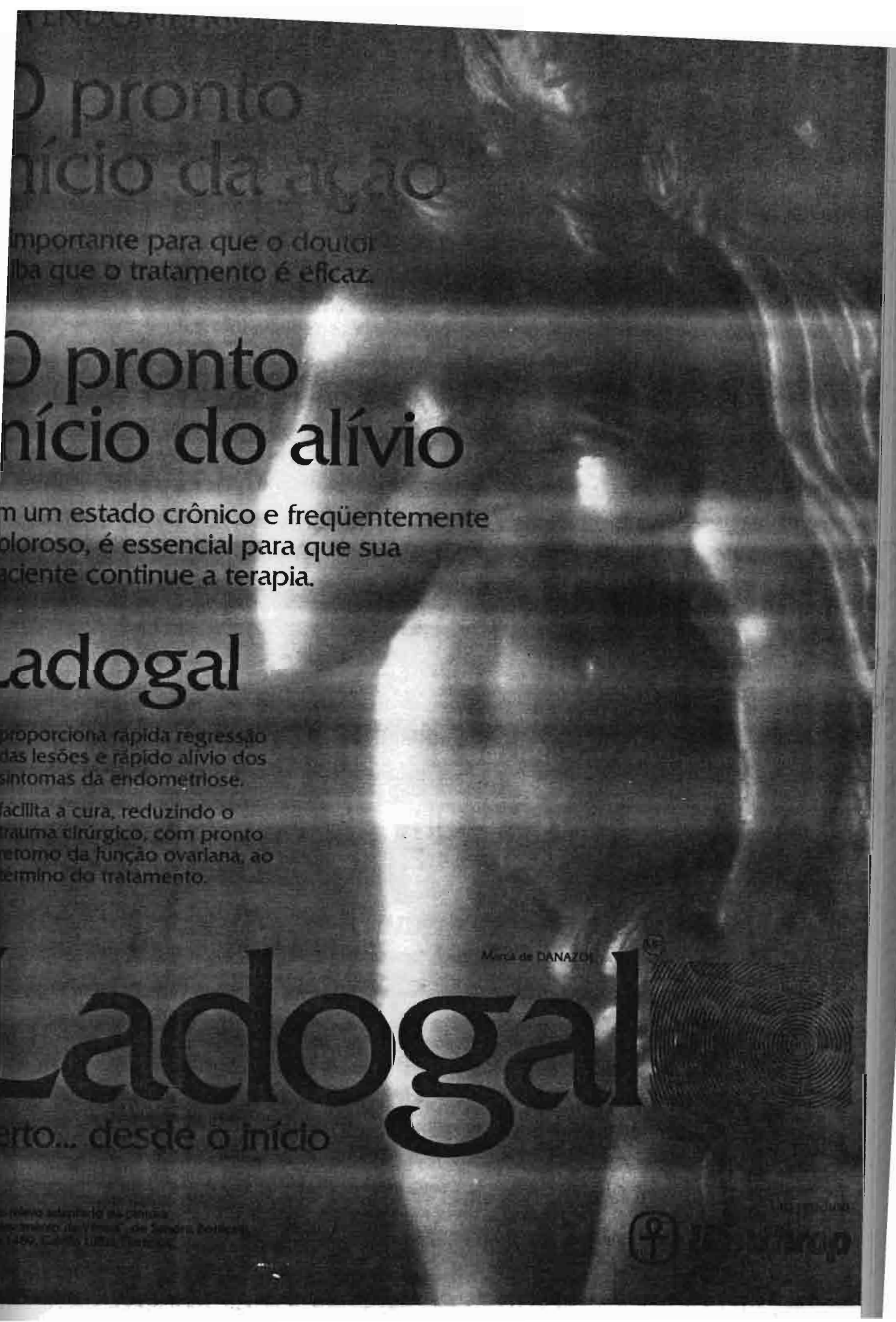






\section{Mio-Citalgan Elimina a lombalgia no mesmo dia}

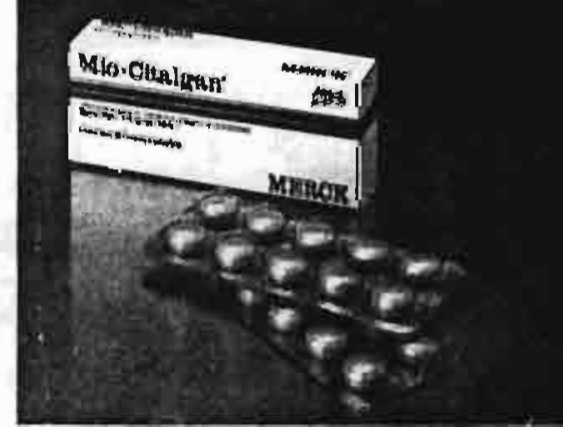

O miorrelaxante decisivo

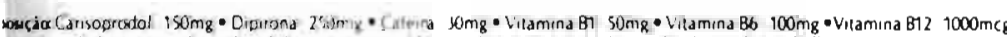

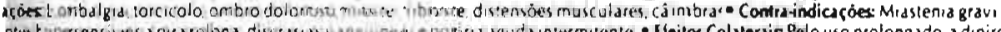

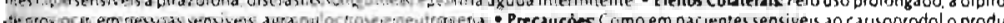

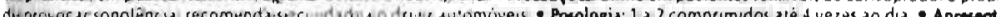
mbalagem com 20 compumidos
- Relaxa a musculatura contraturada.

- Elimina rapidamente a dor

- Não causa sonolência

\section{MERCK}

MERCK S.A. - Indústrias Quimicas

Estrada dos Bandeirantes, 1099

CEP 22710 - Rio de Janeiro - RJ 


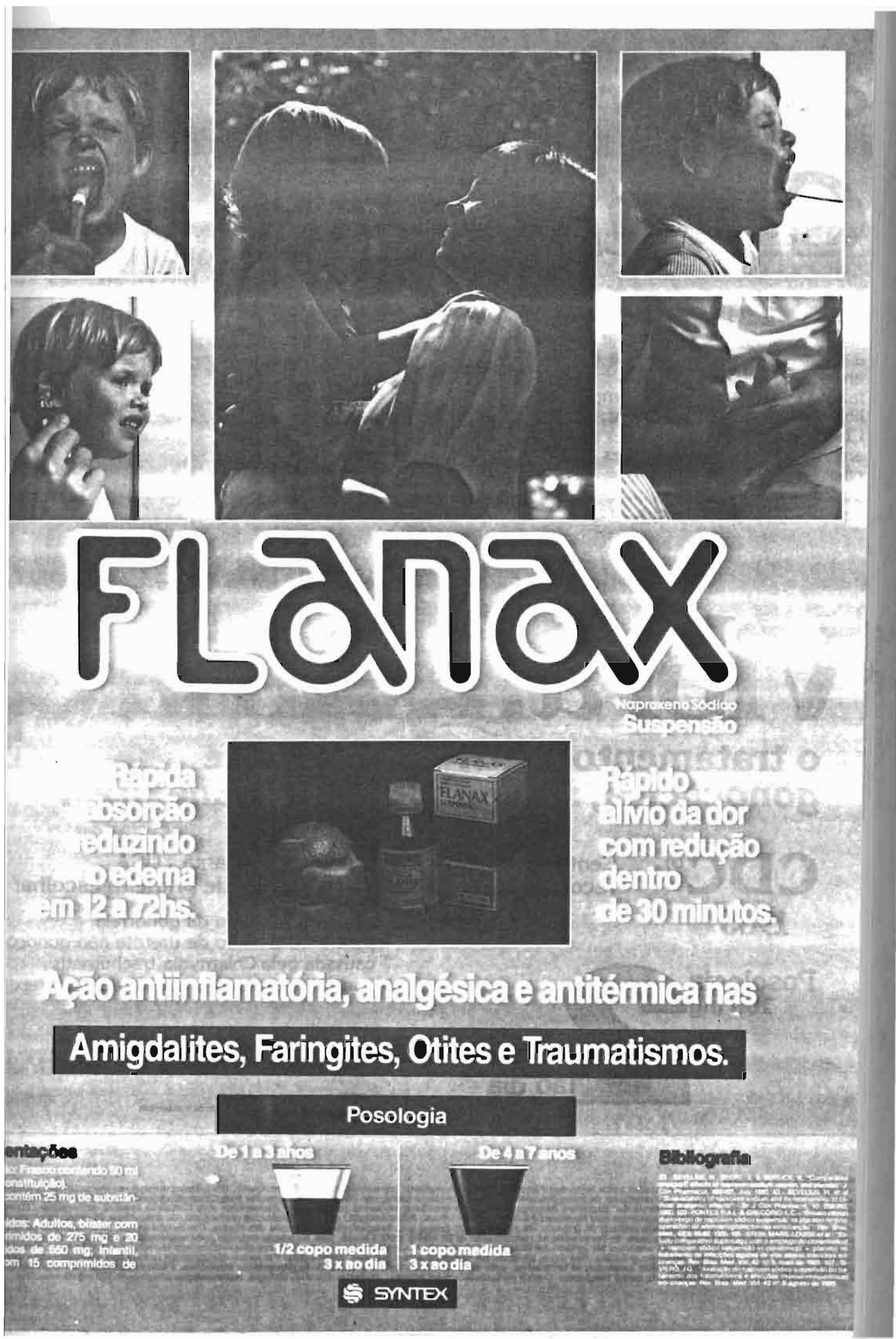




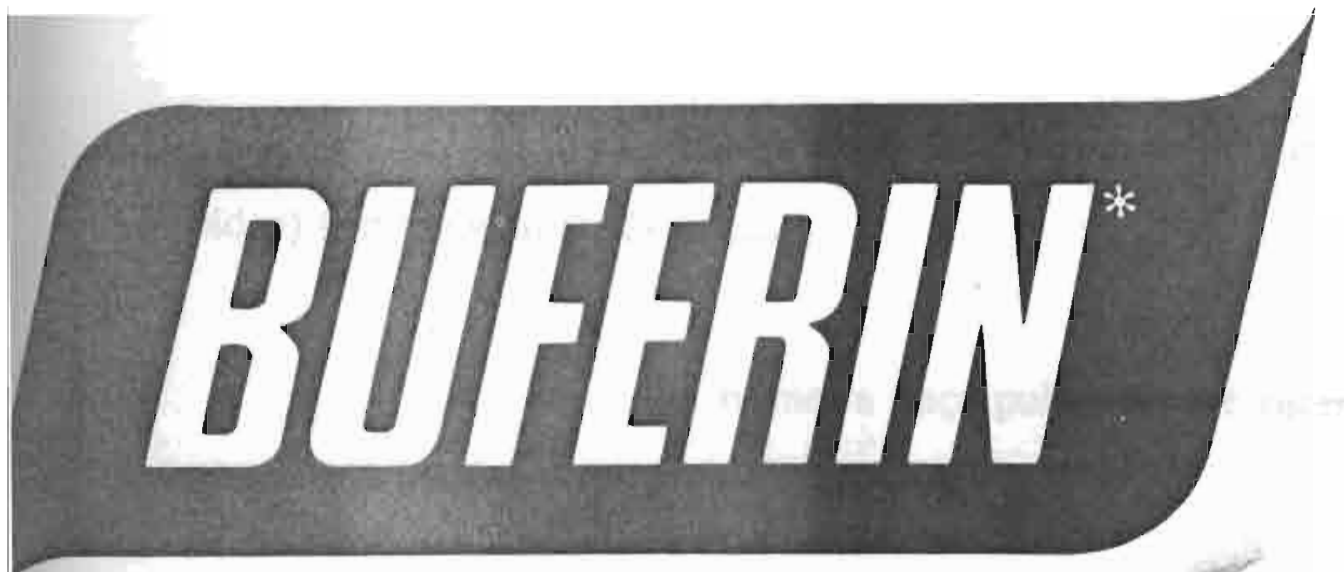

\section{Protege e resolve com rapidez}

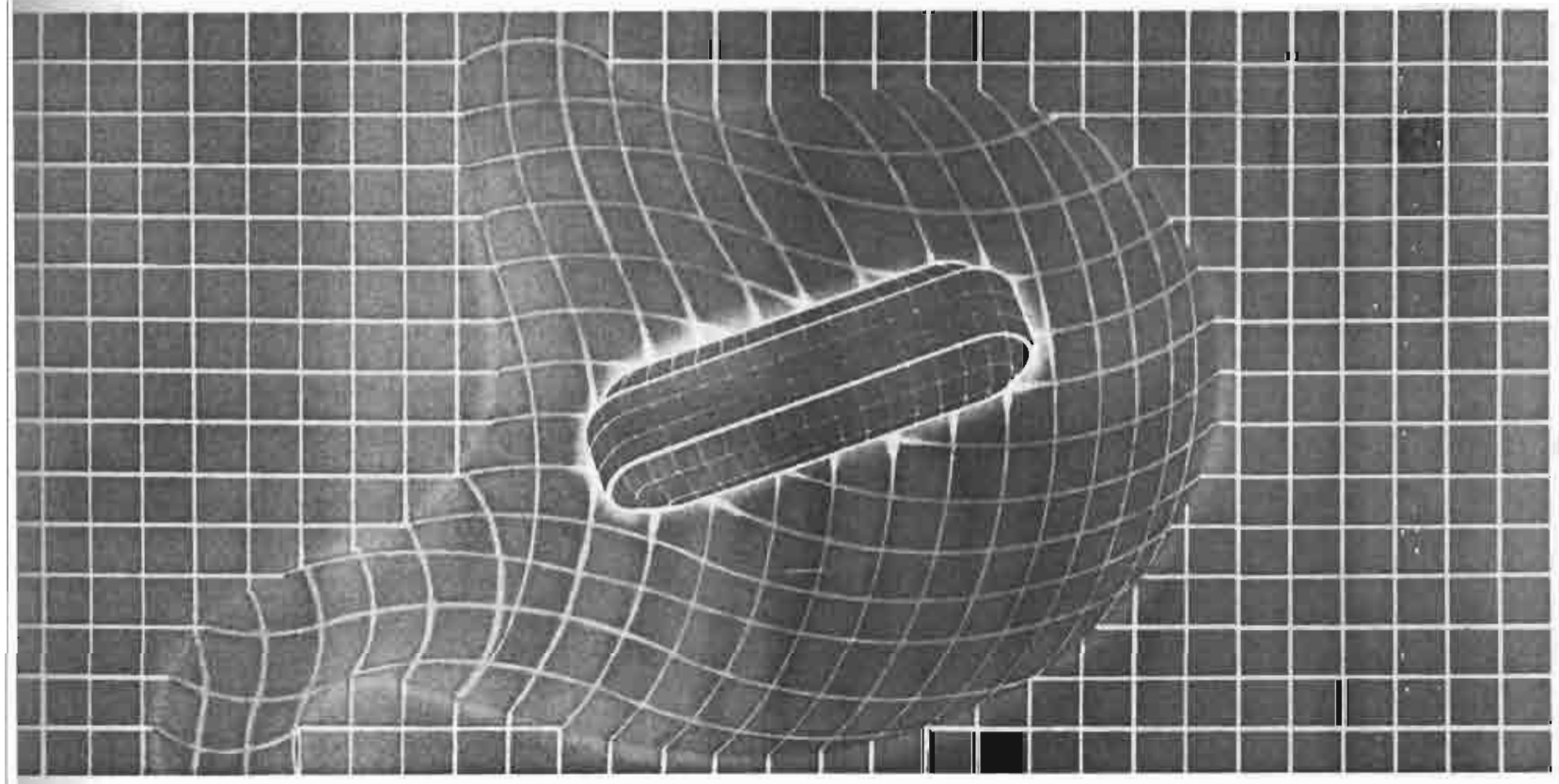

\section{diferença está em} vestir o estômago não o comprimido.

erin é o primeiro analgésico, antitérmico tiinflamatório constituído pela thinação perfeita do Ácido

tilsalicílico com dois antiácidos ponantes (Di-Alminate), em iprimidos de dupla camada, evitando tos gastrolesivos e proporcionando urança, eficácia e rapidez de ação.

\section{uferin tem ação duas} zes mais rápida e eficaz.

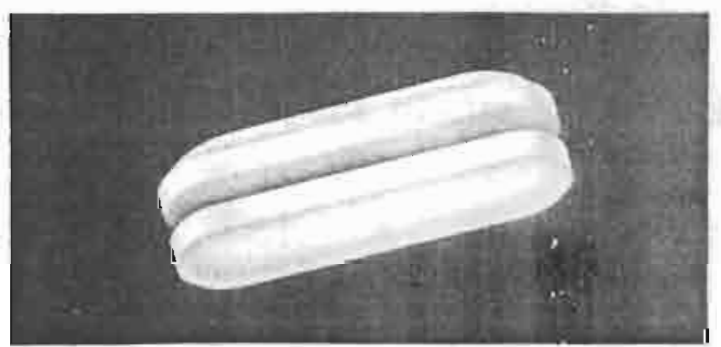

\section{ıferin é de uso genérico.}

cado em todos os modelos de dor, febre e processos inflamatórios.

ssentação: frascos com 20 comprimidos. 
Vemos, nestas ilustraçoes, a ideia de eficiencia simbolica (rapidez) associada ao medicamento.

Na primeira peça publicitária é ostensiva a presença da . eficiência (rapidez):

- "Pronto início da ação"

- "Pronto infcio do alívio"

- "Rápida regressão das lesões e rápido alívio dos sintomas"

- "Pronto retorno da função ovariana".

Da mesma forma, na segunda peça, a presença da eficiência também é clara:

- "Elimina a lombalgia no mesmo dia"

- "Elimina rapidamente a dor".

No mesmo sentido, a terceira peça mostra a eficiência simbólica do medicamento.

- "Rápida absorção..."

- "Rápido alívio da dor"

O contraste fotograffico entre a dor na consulta e o sorriso fora dela, no mesmo quadro.

A mesma "rapidez" está presente na quarta peça: 
- "...Protege e resolve com rapidez"

- "...proporcionando segurança, eficácia

e rapidez de açăo"

- "...tem ação duas vezes mais rápida e eficaz".

\subsubsection{2 -O medicamento e a economia simbolica}

O medicamento faz a "economia simbólica" dos tempos demorados da saúde : do largo tempo necessário para que ocorram as mundaças nas estruturas sociais e produtivas geradoras de doença ; do largo tempo necessário para que ocorram mudanças de comportamentos relacionados à saúde ; do largo tempo de espera das consultas nos serviços públicos; do largo tempo necessário para que a criança nasça naturalmente; do largo tempo para se fazer uma boa consulta médica,etc.

Nesse sentido vale mencionar alguns depoimentos e comentários sobre esses depoimentos, presentes num artigo de COMAROFF (21) que será analisado em profundidade no capítulo II- em que o referido autor detecta e critica depoimentos de médicos sobre o medicamento como símbolo.

Nesse sentido coloca o autor o depoimento do Dr. B : "At times it can be a quit good thing to give a placebo.But the more time you have with the patient, the less placebo is necessary" (pag.85, destaques nossos).

Diz COMAROFF, comentando outro depoimento, do Dr.E : "He (Dr.E)believes that the patient actyally benefits from the ritual of beeing treated as ill. And this belief seems to justify the use of pseudo scientific thecnics wich 
provide the doctor with a strategy for dealing with trivial illeness in a rapld and . effective manner (pag. 86, destaques nossos).

Afirma o mesmo autor mais adiante: "Many doctors appear to treat vage or trivial symptoms in this manner : difficult or lenghty explanations are forgive in favor of the simple ritual of placebo prescriptions" (pag.89, destaques nossos).

Na mesma linha, afirma LANDAMAN (44) : "Frequentemente a prescrição de medicamentos é feita pelo médico para livrar-se do paciente o mais rápido possível e não perder tempo esmiuçando mais as causas de sua sintomatologia" (pag.42, destaques nossos).

\section{I.2.13 - Eficiência simb6lica e cumprimento de papéis}

Vamos tentar encaminhar agora 0 problema presentemente discutivo, explorando a questão sob o ângulo do indivíduo e da sua função produtiva no sistema capitalista de produção.

Existir, na nossa sociedade capitalista contemporânea, é o resultado de um esforço permenente . E isto para todas as categorias sociais.A reprodução física e social é uma tarefa constante. O medicamento faz parte integrante . deste esquema. Como o alimento é a mercadoria que se encarrega de satisfazer a exigência diária de reprodução física, também o medicamento é a mercadoria que entra em ação para restabelecer as condições de normalidade quando estas são afetadas por situaçōes conjunturais (doenças agudas) ou estruturais (doenças crônicas). 
Viver, nessas socledades, implica num permanente e ininterrupto cumprimento de tarefas, que inclui ate coisas que nåo săo habitualmente vistas como tarefas. É preciso nåo apenas trabalhar (preencher relatórios, inspecionar obras, terminar um romance,etc.), mas tambem dormir, ir a festas, receber amigos, comer, exercer a sexualidade, etc. Adoecer, neste contexto, figura como um parênteses nessa exigência. 


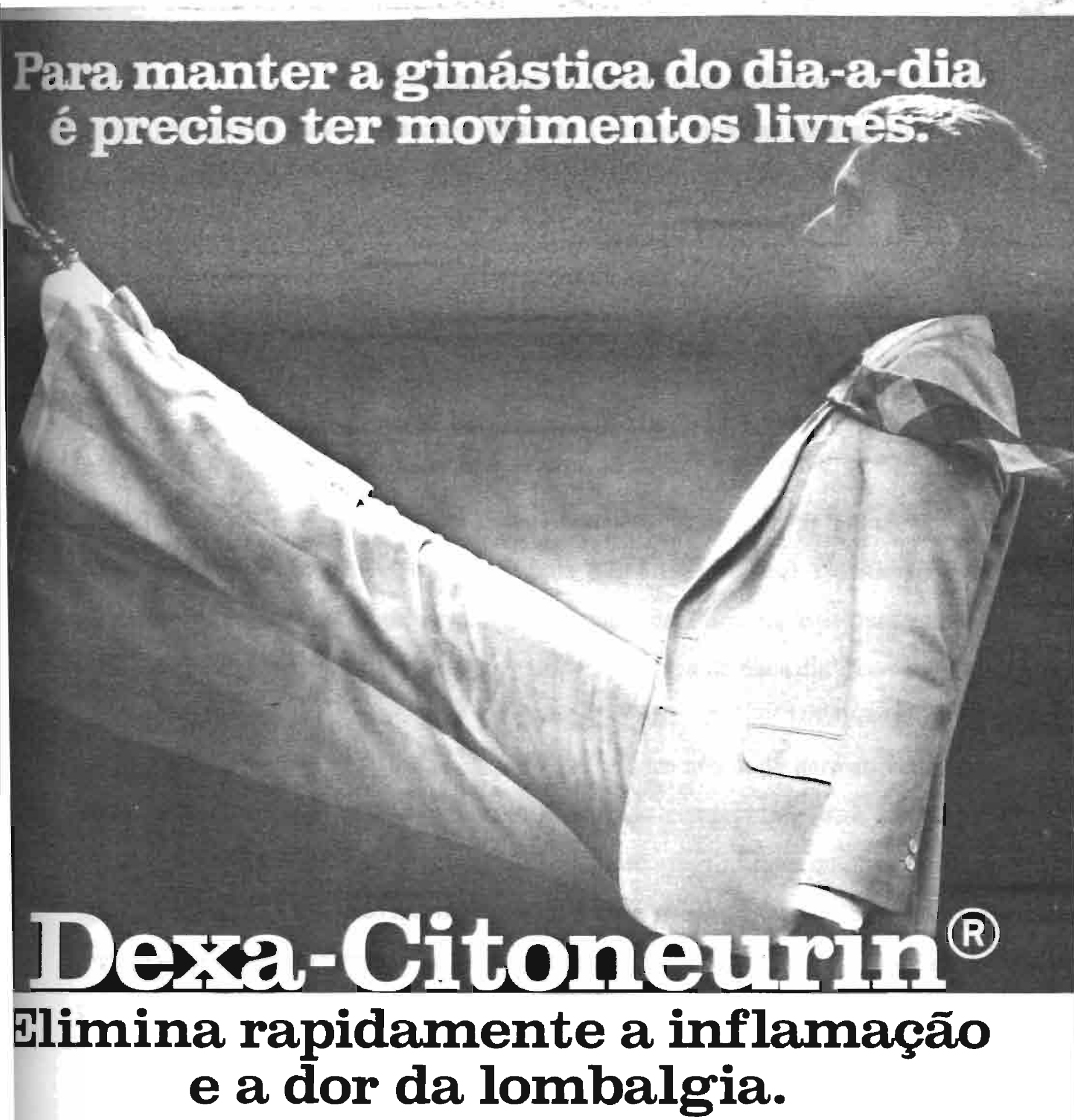

desce, pula, vira para cá, ura lá, se pendura, segura e em dia, quem está em ide,vive numa permanenistica.

ta um pequeno gesto em lara uma dolorosa parada: lalgia.

jitoneurin elimina rapiite a dor e a inflamaça endo o paciente às suas des normais, com a com. a ação da dexametasona corticosteróide cuja poantiflogistica é 5 a 6 ve- zes superior à da prednisona. Essa potente ação antiinflama tória da dexametasona reduz a irritação dos terminais nervo sos, com alta eficácia antiinflamatória e analgésica já nas pri meiras aplicacões, tanto nas do res de lombalgias, como tam bém de sinovites, bursites, tendinites e ciática.

A combinação das vitaminas neurotrópicas: $B_{1}, B_{6}$ e $B_{12}$ de Dexa-Citoneurin completa a açāo da dexametasona, sendo de particular importância a ativida-

6o: Injetável: Ampola I - Vitamina B1...100mg, Vitamina B6,..10Gug, Vitamina mig. Procsins ..50mg, Ampola II - Adetato de Dexametasona .4rog, Comprimidoe: Vita

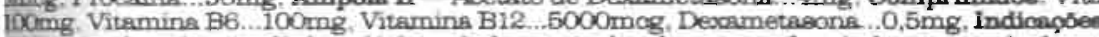
inovite, burgite tendinite, ciatica, sindrome ombro-brago agud.s, findrome cervicel agr

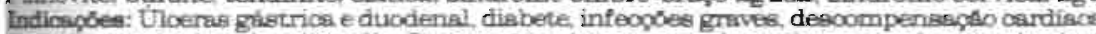
infulo ventrioular e braticardis. Precsugbes: As meernas de qualquer corticoterapis siste ingla: Ampoias: 1 aplicapab intramuacular a cads 2 ou 3 dias. Comprimidos: 2 a 6 comprim.

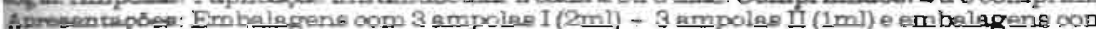

de antiálgica destas vitaminas. Outra vantagem é a praticidade posológica do injetável: 1 ampola a cada 2-3 dias com a mesma eficácia de similares com aplicaçōes diárias.

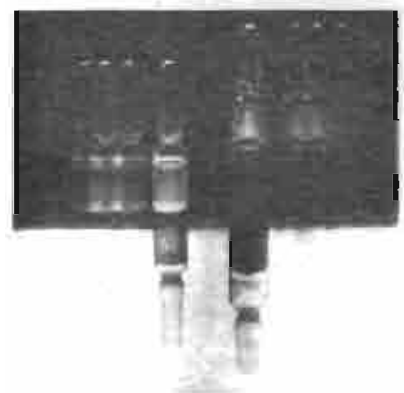

MERCK

MERCK S.A Induntrias Quimions Estrada dos Bandeirantes t. Ogrt 
Esta peça explora basicamente a ideia do medicamento como "passaporte" para o exercicio diário do trabalho, quando ele 6 interrompido pela lombalgia :

"E, basta um pequeno gesto em falso, para uma dolorosa parada: a lombalgia."

"...elimina rapidamente a dor e a inflamação devolvendo o paciente às suas atividades normais."

A parte visual é muito expressiva apresentando um contraste entre o "executivo" (denotado pela roupa de trabalho) e a sua situação visual(fazer ginástica), incompatível com a roupa de trabalho, isto para indicar, visualmente, de maneira expressiva, a metáfora : "ginástica do dia a dia".

De fato, aquele que adoece não pode permanecer muito tempo doente, porque ficar doente implica em nāo cumprir tarefas, e isso não é admissível, ou é negativamente sancionado. Das decorre o fato de que ou o doente ignora a sua doença (quando a considera banal: ver a respeito BOLTANSKY (10) ), e segue cumprindo normalmente as suas tarefas, ou se dedica à tarefa específica de . eliminar a doença como obstáculo ao pleno cumprimento das outras tarefas.

Desse fato decorre a importância e o significado transcendente do medicamento. Ele é o recurso fácil e rápido que permite o imediato restabelecimento da tarefa.

A saúde, nestas sociedades, pode então ser vista, também, como a capacidade de cumprir tarefas. 
As expressóes: "pronto restabelecimento" (na categoria dos sintagmas cristalizados de cumprimento) e "pronto atendimento" (na categoria dos sintagmas cristalizados do discurso da "saúde") traduzem, perfeitamente, esta exigencia social.o medicamento, por sua vez, é o meio por excelência para a obetençāo dos "prontos restabelecimentos e atendimentos".

No contexto do problema que nos ocupa, a metáfora do papel social nos parece interessante justamente porque deixa claro o caráter imperioso da tarefa, a que nos referimos acima.

De fato, tomando a metáfora no seu conjunto e à serio, e imaginando a vida (ou a urbe) como um enorme palco, fica claro que o nāo cumprimento, por algum ator, do papel que lhe cabe, implica numa situação constrangedora, anômala e, no limite, insuportável, levando à suspensão do"espetáculo"

Como não há vida fora do "palco", ao ator cabe recuperar o seu papel ou buscar outro papel alternativo,sob pena de entrar em processo de marginalização social.

Dir-se-á, na esteira da sociologia parsoniana que existe um papel de doente ("sick role") . Mas, é claro que se trata de uma espécie de anti papel, na medida em que estar doente $\varepsilon$ estar,permanente ou temporariamente, total ou parcialmente, "inválido", "incapacitado para o trabalho" ( e também para o lazer).E estar inválido, ou seja, sem valor, inútil, é estar não capacitado para consumir e gerar mercadorias, o que é um estado suportável socialmente apenas por um curto espaço de tempo . 
Parece pois quase cristalina a relaçăo entre a necessidade de cumprimento de papeis e o medicamento na medida em que este funciona como uma arma sempre disponivel destinada a abreviar ao máximo (chegando. frequentemente a evitar qualquer soluģa de continuidade) as manifestaçóes de morbidade que levam à interrupçăo no desempenho de papéis.

A este respeito, vale citar a mais que sujestiva peça publicitária vigente nos nossos canais de televisăo comercial (1987).A peça pode ser assim descrita, resumidamente: mostra um ator (Raul Cortez) preparando-se no camarim para entrar em cena.O ator dirige-se para o telespectador e pergunta se este sofre de torcicolo. Afirma que ele (o ator) resolveu este problema com o medicamento "x" e em seguida entra em cena".

Como este tipo de mensagem implica (até porque há uma relação direta face à face-o ator olhando de frente para as câmeras) identificação entre ator e expectador, o sentido por ela passado ê o de que "vocè, telespectador,é também um ator importante e o medicamento x está aí para não deixar voce perder a "sua" cena.

São vários os exemplos de possíveis peças publicitárias equivalentes, que caberiam perfeitamente em nossos videos: a mãe refriada, impossibilitada de levar os filhos à escola, resolve o seu problema com o medicamento $\mathrm{x}$; o executivo com dor de cabeça às vésperas de uma reuniảo, que resolve o seu problema com o analgésico y ; o adolescente com indisposição de estômago que nāo pode faltar ao baile onde lhe aguarda a bela namorada e que resolve o seu problema com um bom anti ácido.

A título apenas de exeplificaçāo, é interessante lembrar outras duas peças publicitárias com o mesmo sentido e que figuravam (1987) em 
nossos videos : a do rapaz que comeu demais e náo consegue tocar na banda, e que resolve seu problema com um anti-ácido e a do participante do coral cuja tosse e resolvida no ato pelo maestro com a administraçåo de uma pastilha para a garganta.

Cumpre acrescentar que o não cumprimento do papel acarreta năo somente a solução de continuidade no inexorável desenrolar da vida, como também coloca o ator inadimplente sob ameaça de substuição, considerando o quadro geral de uma sociedade e culturas altamente competitivas.

O medicamento é então uma arma importante para a sobrevivência dos atores sociais no quadro de uma sociedade concorrencial de papeis.

E os atores, ao se assumirem como tais, justificam e reproduzem, por via de consequência, a própria peça da qual são atores, ou seja, o próprio sistema social.

Considerando a socieadade da perspectiva de um pensador como FOUCAULD, seria lícito ver o medicamento como um componente, no campo da saúde, daqueles variados mecanismos sutis de controle social, onde o poder nāo se manifesta ostensivamente (precisamente porque é internalizado) não aparecendo sob a forma de um tirano a "vigiar e punir" os cidadãos, para garantir a "ordem natural das coisas", mas como uma peça deste controle social difuso (tanto no sentido de pouco explícito como no sentido de difundido)

E claro que a sociedade capitalista não dispensa, na área da saúde também,tiranos e tiranetes para exercer o controle social. O médico da medicina de grupo, por exemplo, exerce, tendo o cuidado médico como álibi, o papel de controlador de māo de obra. 
Mas o controle social é uma mega funçăo social, ou seja, algo que perpassa todas as instancias e níveis do social, nâo podendo, obviamente,ser exercida, em todas as situaçoes, por um vigia exterior.Porisso exige a montagem, em paralelo, de um sistema interior ( ao indivíduo ) de vigilancia, do qual, no campo da saúde, o medicamento é uma das peças.

O que se procurou indicar aqui, no quadro geral do problema da eficiência e efićácia simbólicas, é a analogia entre o medicamento, a saúde e o funcionamento social deste mesmo medicamento como instancia de" pronto atendimento "(eficiência), responsável, no caso de um evento mórbido ou supostamente mórbido, por permitir, pela sua pronta intervenção, que seja dado andamento ao cumprimento de papeis sociais, que é um dos mecanismos básicos de controle social em formações sociais como a nossa. 
CAPÍTULO II - RELAÇÕES SIMBÓLICAS MANTIDAS COM O MEDICAMENTO PELO PRESCRITOR MÉDICO. 


\section{II.1 - Introduçấo.}

Neste capitulo pretendemos tecer algumas consideraçóes • relativas ao ponto de vista do médico sobre o medicamento.

Nossa idéia é trazer à tona alguns indicadores de que o médico entretém relações năo apenas terapêuticas ou meramente instrumentais com o medicamento, mas que o seu ponto de vista sobre o referido objeto comporta, também, uma dimensão simbólica, expressada numa relação simbólica com o medicamento.

Este capítulo não tem a mesma importância e nem o mesmo "status" que os outros dois, pelas razōes que expusemos anteriormente .Porisso, não trabalhamos com dados (mesmo qualitativos) primários de médicos . brasileiros.

Cremos, no entanto, que não há razão para duvidar, a priori, que o ponto de vista destes médicos brasileiros sobre o medicamento comporte uma dimensão simb6lica; até porque o ingresso tardio do país na era do capitalismo moderno tem tudo para favorecer um movimento de crença mítica -também, evidentemente, da parte dos médicos- na tecnologia moderna, da qual o medicamento é um importante exemplar.

Os trabalhos de BARROS (3), CORDEIRO (23) ), GIOVANNI (32), LANDMAN (44), SASSAKY (69) e TEMPORĀO (74) que, todos . eles, em algum momento, tocam no comportamento do médico brasileiro em relação ao medicamento, fornecem algumas indicaçōes nesse sentido. 
A relaçăo simbolica com o medicamento é uma relaçăo (muitas vezes inconsciente) que um sujeito individual ou social mantém com uma coisa, onde esta coisa está substituindo, ou está no lugar de, ou está representando outra coisa ou estado.

Esta definição de relação simbólica está baseada na propria definiçáo de signo enunciada por PIERCE (59).

Não é suficiente, no entanto, enunciar o problema em termos genéricos. Este $\mathfrak{e}$ apenas um primeiro passo. Em dois trabalhos anteriores (45) (46) que consagramos ao tema inicamos uma tentavia de aprofundamento desta relação simbólica.E preciso ir mais adiante e entender, sobretudo, que o uso simb6́lico de medicamentos pelos atores do drama terapêutico, ou da saúde não pode ser visto como uma tentativa de produzir um engodo uma mistificaçāo, uma fantasia, enfim como uma tentativa de induçāo de um comportamento irracional ou primitivo.

A proposta da relaçāo simb6lica com o fetiche (e o remédio é um deles) tem que ser vista como envolvendo uma relação produtiva, na qual está imbutida a possibilidade da existência de uma crença de base, da parte do sujeito desta relação, na eficácia simbólica do fetiche, ou seja, no fato de que este fetiche $\varepsilon$ um objeto prenhe de poder ou de possiblidades de produzir efeitos específicos concretos.

No caso do medicamento, a relação simb6lica com o fetiche é ainda mais complexa porque a crença na efićácia simbólica dele está indissoluvelmente associada à crença na eficácia simbólica da ciência (da qual o remédio é um produto). 
E claro que a intensidade e a modalidade desta relaçâo simbolica com o medicamento variará de acordo com as características proprias do prescritor e do paciente; em funçâdo tipo de enfermidade; em funçăo do contexto social, etc.

\section{II.2 - Relações simbólicas e relacões terapêuticas.}

Antes de entrar especificamente no tema, é preciso que se entenda uma idéia anterior: as relaçōes simbólicas com o medicamento existem associadas às relaçōes terapêuticas com o medicamento, ou mais precisamente, lastreadas nesta e na sua eficácia real e prática, eficácia esta reforçada e sistematizada através de um gigantesco esforço ideolbgico empreendido pelos meios de comunicação de massas, pelas escolas médicas e outras instituiçoes que, juntas, configuram o que ALTHUSSER (1) chama de "Aparelho Ideológico de Estado da Saúden.

Este esforço ideológico visa essencialmente consolidar o mito da doença como "coisa orgânica", a ser investigada e resolvida pelo medicamento, entre outras mercadorias de saúde, a nível do corpo.

Agora parece ganhar um sentido mais nítido a ideia, colocada no início deste trabalho, de que o medicamento não é uma mas tres coisas (agente quimioterápico, mercadoria e símbolo) ao mesmo tempo, e que preenche tres funçōes correlatas: uma função econômica, uma função terapêutica e uma simbollica. 


\section{II.3 - Relacoes simbollicas.}

Abordando especificamente o tema, dirframos que temos relaçóes simbólicas mantidas com o medicamento năo apenas pelo paciente e por toda uma categoria de agentes sociais como o vizinho, o farmacêutico, etc., mas também pelo sujeito institucional médico.

Com efeito, so numa atitude ingênua poder-se-ia imaginar que pelo simples fato do medicamento ser uma tecnologia, de jure, manipulável apenas pelo médico, este a usaria sempre e necessariamente como o ferreiro usa o martelo e a bigorna.

COMAROFF (21) em seu estudo sobre o efeito placebo dos medicamentos ilustra bem este fato ao descrever a opiniāo de um médico (DR. A) sobre o poder do medicamento:

\section{"Dr.A suggests that all prescribed (em itálicos no} original)medication is invested with a simbolic power by his patients, and expresses a belief in the value of reinforcing the faith in this power. (pag. - grifos nossos).

Que poder simbólico é este de que fala COMAROFF, que está presente em todos os medicamentos prescritos e que o Dr. A crê necessário reforçar?

Antes de tentar responder $\varepsilon$ preciso entender a consulta médica como um parênteses organicista no espaço da saúde/doença .

Neste espaço restrito e restritor fala-se, e agese,pragmaticamente sobre o enfermo (real ou imaginário). 
A doença, quando localizada no espaço da consulta médica (e toda a pressăo social t no sentido de encaminhá-la para este espaço) já está reduzida a um fenômeno orgânico a ser enfrentado, a este nivel, pelos instrumentos ou tecnologias pertinentes.

Neste contexto, é evidente que o medicamento reina inconteste.

Agora podemos tentar encaminhar a resposta à nossa questão: o poder simbólico do medicamento pode estar relacionado à crença de que ele $\varepsilon$ uma constante na cena terapêutica, ou seja, que ele deve estar sempre presente quando se trata de enfrentar a enfermidade, entendida como uma realidade basicamente orgânica. A crença postula que, frente à doença, a saúde só pode vir de um objeto (como o medicamento), que passa assim a incorpora-la, a representa-la, a simboliza-la.

Outra função simbólica é destaca por COMAROFF, no mesmo estudo, quando afirma que o medicamento usado como placebo preenche, para o médico, a importante função de reassegurar o seu poder ou autoridade frente ao paciente e a ele mesmo em situaçōes (bastante frequentes) de incerteza. Afirma o referido autor: "...placebo therapy may be comprehended as a repertoire of thecniques wich enable the general practicioner to deal with complex and uncertain situations in a manner wich conserves his time and energy (...) Its performance, like that of most rituals, concerns the attempt to contain uncertainty: it is upon this that the power of the practicioner depends. And placebo therapy ... provide means of limiting such uncertainty in the clinical process" (pag.90). 
Que sentido podemos tirar das colocaçסes de COMAROFF (21), que interessam ao nosso tema?

Primeira, a de que o medicamento pode ser 0 representante ou símbolo de si mesmo, isto é, pode ser o símbolo de uma agente quimioterápico. De fato, em si, o placebo é nada. Ora, se êle é nada e funciona como medicamento ele está, simbolicamente, no lugar do medicamento.

Além disso, na definição pierceana de signo, este é algo que está, para alguém, por outra coisa. Ora, no caso, o medicamento, quando usado como placebo, está, para o médico (mas não para o paciente) no lugar do verdadeiro agente quimioterápico.

Além deste primeiro sentido, o medicamento/placebo está funcionando, também para o médico, como símbolo da própria relação terapêutica na qual este médico deve estar sempre em posição de força frente ao paciente, porque o medicamento, simbolizando saúde ou cura - ou, no mínimo, expectativa de cura - permite que seja mantida - mesmo em situaçōes de insegurança do médico - a relação terapêutica, cujo objetivo é justamente o de promover a cura.

No momento em que $\varepsilon$ assegurada, pelo medicamento, a cura ou a possibilidadde de cura, é também reproduzido o poder do médico sobre o paciente, na medida em que o médico é o dispensador de medicamento. 


\section{II.4 - Uma visâe paradiemática}

Desenvolvendo um pouco mais a idéla do poder do médico na escolha e na administraçăo do medicamento, e considerando o problema do ponto de vista paradigmático (das relaçôs ou/ou de que fala JAKOBSON (40), e considerando o médico como um "native speaker" da medicina como linguagem) podemos dizer que o médico, enquanto instituição abstrata é uma entidade mítica que retira parte importante de seu poder do fato de, em condições ideais, ser capaz de desenvendar um duplo mistério:

a) dentre as mui variadas doenças que o individuo pode ter, o médico seleciona a "verdadeira";

b) dentre os mui variados remédios disponíveis, o médico seleciona o "adequado" para a doença que descobriu antes.

Num depoimento recolhido na fase de préteste do instrumento, falando a respeito de por que o medicamento cura, colocava o entrevistado:

"Porque deve ser assim, né, assim, eles (os médicos) entendem todo tipo de doença, com todo tipo de gente. Então eles sabem ... qualquer doença que a pessoa tem eles sabem, sabem né. Se eles estão passando (o medicamento) é porque eles sabem, porque eles estudaram todo tipo de doença, em qualquer ser humano. Então eles estão bem conscientes, né. Porisso então eu acho que é bom. As vezes tomo algum remédio, porque precisa passar alguma coisa, e funciona..."

E também o que o Dr. "K", do já citado estudo de COMAROFF, afirma, em outros termos: 
"I suppose that when im not really sure about attaching a label to a set of symptoms, but $i$ feel it is not serious, I should tell the pacient to go home and wait and see. If the symptoms persist, then he should comme and collect a prescription. But in practice, it is better do give the impression that things are cut and dried.It inspires more confidence to put a name to a condition and give something for it" (pags. 8, 9, destaques nossos).

A "confiança" (que é o outro nome para o poder) nasce então da capacidade de "dar nome" (e o nome é também um símbolo) a uma condição, ou seja, de desevendar, através da nomeação, a "doença sem nome" e de "dar alguma coisa" para esta doença, ou seja, enfrentar a entidade malefica agora nomeada, com uma arma da qual só o médico pode ter o "porte".

O "nome da doença" e o "dar alguma coisa par ela" (o medicamento) são, pois, dois grandes símbolos do poder médico.

O nome da doença, ou mais precisamente, $o$ ato concreto de dar nome a uma doença, é um comportamento que tem como efeito, como resultado pretendido, o poder.

Dar nome a uma doença preenche pois a importante função simbólica, conferidora de poder ao médico, de dominar ou exorcizar o "mal" através do conhecimento cientffico - já que, na prática social (e a consulta médica é uma prática social) "conhecimento" e "nomeação" são coisas que andam juntas.

Portanto, dar nome a um mal produz um "efeito ideológico ou de poder" como diria VERON (79) na medida em que é uma forma indireta ou um primeiro passo para tornar este "mal" um "bem". 
A outra fonte de poder do médico (dar "alguma coisa" para a doença nomeada) significa que ele é o agente social capaz de retirar do arsenal das ciencias, os instrumentos do "bem", para fazer o "bem".

Esta sua capacidade especifica vem, no entanto, sendo posta em xeque pelo fato de que o medicamento começa a adquirir considerável autonomia como mercadoria e bem de consumo. Fenômenos como como o consumo direto de medicamentos, que descrevemos no início deste trabalho, são, entre outros* indicadores desta tendencia, que pode genericamente ser descrita como resultado da hegemonia da mercadoria médica sobre o ato médico.

Vale notar que esta alienação relativa do médico em relação aos seus instrumentos de trabalho constitui um processo histórico.

Com efeito, como todos sabemos, o médico foi, antes de ser um prescritor de um produto industrial elaborado fora do espaço médico, um formulador, ou seja, um profissional que dispunha de muito maior poder simbólico em relação ao medicamento na medida em que detinha o controle não do nome do medicamento (enquanto bem de consumo público), mas de uma fórmula que não era do conhecimento público. O remédio enquanto fórmula era um património corporativo, que só se transformava em bem de consumo através do formulador** ***.

Com o desenvolvimento do capitalismo e do produtivismo de que fala BAUDRILLARD (6) o medicamento passa a ganhar autonomia relativa

* Como o fato de que o médico é "educado" em farmacologia pelos representantes de laboratório (V.TEMPORÃO (74).

* * Talvez a prescrição incomprensível (69) seja um traço arqueológico desta função formuladora. 
em relaçăo ao seu prescritor, que deixa de ser um formulador e, numa certa medida, produtor do símbolo, para passar a ser uma peça - se bem que muito importante (74) - no esquema de distribuiçăo e comercializaçăo do produto.

Evidentemente, na medida em que o médico nâo é totalmente imprescindfvel para o consumo do medicamento, que existe, comercialmente, independente dele, o seu poder simbólico sobre este produto diminui.

\section{II.5 - Umą visão sintagmấtica}

Considerando agora o problema do ângulo sintagmático (das relações e/e de que fala JAKOBSON (40) dirfamos que o poder do médico se expressaria também, através de relações de manipulação (combinação) frente ao medicamento: dosagens, combinaçōes medicamentosas, compatibilidades e incompatibilidades inter-medicamentos e entre medicamentos e alimentos, bebidas, etc.

Estamos ấ não ao nível do léxico (nível mais simples, mais acessível ao publico-V. BOLTANSKY (10) mas ao nível do discurso, esfera do especialista, do profissional.

Com efeito, quando o médico receita uma combinaçāo medicamentosa, o que ele está fazendo, simbolicamente, é produzir um discurso especf́fico, que é símbolo de poder na medida em que só o médico é capaz de produzilo com autoridade (no sentido que BOURDIEU (11) atribui ao termo)*. - Da mesma forma que so o engenheiro é capaz de produzir, com autoridade, um discurso sobre a
engenharia, o fisioterapeuta sobre fisioterapia, o linguista sobre linguistica, etc. 
Mas a força da mercadoria e tal que mesmo esta autoridade acaba sendo relativada nas sociedades de consumo modernas, especialmente nas de capitalismo selvagem como a brasileira.

\section{Afinal, năo existe a Bula?}

De fato, a bula é um discurso público sobre o mesmo tema (o das interrelações medicamentosas).

Trata-se, é certo, de um discurso ambíguo (pelo menos em nosso pars) porque vazado em linguagem médica mas destinado também ao consumidor não médico.

A título de ilustração, vamos analisar brevemente a bula do medicamento BINOTAL (anexo).

No capítulo "Posologia e modo de usar" diz a bula:

"O preparado deve ser administrado sob prescrição médica. Entretanto, aconselhamos as seguintes doses diárias" (destaques nossos). Segue-se esquema de dosagens para lactentes, crianças, adolescentes e adultos.

A conjunção "entretanto" é o sinal inequívoco da ambiguidade: "O preparado deve ser administrado sob prescrição médica. Entretanto, aconselhamos (ao leigo) as seguintes dosagens". E claro que o objeto do verbo "aconselhar" é o leigo e não o médico. E'claro que se colocassemos o médico entre parênteses, o discurso se tornaria absurdo: "O preparado deve ser administrado sob prescrição médica. Entretanto, acoselhamos (ao médico) as seguintes dosagens". 
O discurso da bula $e$, pois, amblguo já que tem dois receptores que se excluem mutuamente: 0 médico e o leigo.

Finalmente, cumpre analizar o sujeito do verbo aconselhar: afinal, quem está "aconselhando" neste discurso da bula? Quem é este sujeito institucional que se permite e ao qual é permitido falar, com autoridade social ( ) sobre a posologia?

A resposta é que este sujeito é a Ciência reificada na Mercadoria.

O médico (ou mais precisamente, o médico consultante) portanto, já não é mais o único sujeito social e institucional da ciência e da prática médica, habilitado a tecer um discurso sobre combinações medicamentosas. Ele compartilha esta função com a Ciência e os cientistas - aliados orgânicos, no sentido gramsciano da expressāo, dos proprietários da mercadoria medicamento - que avalizam o discurso da mercadoria e, consequentemente, também, uma relação direta do produtor e do cosumidor final.

Assim, parece claro que a bula é uma forma de "socializar" o discurso terapêutico, com vistas a retirar parte do poder simb6lico da mão do médico consultante e investi-lo diretamente na mercadoria medicamento. 
CAPITULO III - O SENTIDO DO MEDICAMENTO DO PONTO DE VISTA DO INDIVÍDUO. 


\section{I.I.I.1 - Introductale}

Mais uma vez é necessário colocar que os depoimentos que constituem a matéria deste capítulo, não representam mais do que uma das vias de acesso ao sentido do medicamento; um dos modos atraves dos quais é possível fazer emergir mais uma parcela do que se acredita ser o sentido do medicamento na formação social concreta brasileira.

A sociedade e os profissionais médicos representam pontos de vista sobre o medicamento ( que analisamos até aqui).A sociedade produz as suas mercadorias e a semiose social correspondente (ou seja, o sentido social das coisas, sem o qual o funcionamento social não seria possível, como coloca VERON (79), explicitamente através da publicidade (o discurso" oficial" da mercadoria), implicitamente no próprio consumo de medicamentos (74) e em arranjos espaciais (como nas farmácias sob a forma de Drug Stores, etc.).

Os indivíduos, por sua vez, representam outro "ponto de vista" ( ver 1.1.9.).

Eles tem como fontes onde se abastecem para realizarem a sua funçāo de atribuidores específicos de sentido, as suas proprias experiências de consumidores da mercadoria e das representaçōes sociais associadas direta ou indiretamente - por exemplo, através da opinião do médico - a essa mercadoria.

E o ponto de vista específico do indivíduo (representado aqui pelo paciente hipertenso) que pretendemos, nesta parte do trabalho, fazer entrar em cena, como mais um dado na tentativa de contribuir para a construção de hipóteses sobre o sentido do medicamento na nossa formaçāo social. 


\section{III.2 - Interpretaça e contextualizaçå}

A análise dos depoimentos dos pacientes hipertensos entrevistados foi feita com base em temas sugeridos pela leitura destes depoimentos.

A leitura de um depoimento determinado sugeria um tema relevante, como contribuição para o entendimento do sentido do medicamento. E na leitura de outros depoimentos, o tema era reencontrado.

Algumas vezes um depoimento trazia um tema particular. Nesse caso, depoimento e tema coincidiam.

Estes dados assim agrupados e interpretados permitiram o levantamento de hipóteses sobre como os indivíduos conferem ou atribuem sentido ao medicamento a partir de sua vivência com este objeto.

Para se tornarem fontes de hipóteses, no entanto, estes depoimentos agrupados e interpretados, sobre o medicamento precisaram ser, também, contextualizados sob pena de configurarem sentidos esparsos, atomizados, subjetivos e portanto de pouca ou nenhuma valia científica (26).

Esta intepretaçāo/contextualizaçāo se fez com base numa determinada perspectiva térica, que permitiu ou possibilitou a superação seja do empiricismo inicial do dado bruto,seja do subjetivismo interpretativo, inserindo os depoimentos num determinado contexto histórico e socio cultural.

Assim contextualizados,os depoimentos permitiram a confecçāo de hipóteses sobre o sentido do medicamento do ponto de vista dos usuários , enquanto indivíduos vivendo no espaço de uma determinada cultura e de uma dada formação social concreta e num determinado tempo*.

\footnotetext{
* Esta abordagem mais abrangente - que situa o individuo como membro de uma sociedade $e$ de uma
} 
Este contexto tomou então a forma, neste trabalho, de uma rede de temas e sub-temas - a questáo do "natural" x "artificial"; a eficiência e a eficácia simbolicas; o medicamento como instrumento de controle social; a questáo do medicamento e o homem concebido como máquina,etc. - que constituem algo que, metaforicamente, poderiamos chamar de "meio ambiente ideológico"*.

O sentido do medicamento para o usuário, segundo cremos, pode então ser buscado - e este trabalho constitui um primeiro passo nesta busca - considerando este "meio ambiente" como referencial.

Desta forma, o "meio ambiente ideológico" $\varepsilon$ considerado, metodologicamente, dentro de uma perspectiva dialética, como um instrumento de leitura e interpretação dos depoimentos que, uma vez interpretados, retroagem sobre o "meio ambiente", fornecendo elementos que permitem construi-lo como um campo dinâmico* de sentidos.

cultura, vivendo num dado tempo histórico - permite situar este trabalho no contexto daqueles onde os CAHPs não sâo entendidos unicamente por referência ao conhecimento cientifico (comparado ao qual, quase sempre, aparecem como um produto degradado ou como um erro).

Caso este estudo, que envolve os CAHPS em relação ao medicamento, tivesse como modelo de CAHP a visão "científica" (leia-se médico/farmacológica) do medicamento, estaria desconsiderando - fato - importante para a Saúde Pública e para a Educação em Saúde Páblica - de que o medicamento, na nossa sociedade, e,também, um objeto de consumo de sarude .

Este desconhecimento induziria a uma visão parcial e fragmetária sobre o sentido do medicamento porque, na nossa sociedade, faz parte integrante do conhecimento, das atitudes, das habilidades e das praticas normais dos individuos - médicos inclusive - frente ao medicamento o fato dele ser visto ou percebido como um objeto de consumo de saúde.

Portanto, estes CAHPs que comportam esta visão não implicam erro ou desvio mas - considerando o conterto histórico da sociedade e da cultura vigentes - um comportamento funcional para uma sociedade e uma cultura que tem como valor central o consumo.

- Lembrando sempre que o ideológico está intimamente mesclado ao social (ao qual dá sentido, como assinala VERON (79); de modo que ao falarmos de "meio ambiente ideológico" estamos efetivamente utilizando linguagem figurada já que os temas, sub-temas, assuntos que o constituem fazem parte integrante da vida do social e não da vida do espirito.

** O proposito aqui, de acordo com a perspectiva dialética que norteia o trabalho, $€$ fugir das visōes que analisam o fenômeno ideológico como ação unilateral de imposição de ideias, isenta de contradiçōes e conflitos. 
Neste campo impera, ao mesmo tempo, um processo de hegemonia ideológica e um movimento de conflito ideológico, envolvendo sujeitos produtores de sentido: a sociedade e a cultura (através dos Aparelhos Ideologicos de Estado de que fala ALTHUSSER (1) e os individuos, ou grupos (por exemplo, tipos de pacientes), ou categorias sociais (por exemplo, os profissionais médicos) não hegemônicos.

Ao final deste trabalho espera-se obter um desenho. preliminar deste "meio ambiente".

Tal desenho preliminar permitirá que se obtenha materia prima, ou, mais precisamente, utilizando-se a terminologia de HJELMSLEV, na versão de METZ (52), "materia do conteúdo", para a confecção de hipóteses.

Constituem "materia do conteúdo", por exemplo, os temas de novela televisiva no Brasil: a "novela das seis" com seus temas históricos (a escravidāo, a imigração), a "novela das sete" com seus temas relativos à vida contemporânea, vistos através de uma 6tica humorista, a "novela das oito" com seus temas "sérios", dentro do gênero "drama" ou "tragédia". Estes temas - a matéria do conteúdo das novelas - podem ser vistos como ingredientes para a confecção deste tipo de peça televisiva, "materia prima de assuntos", da qual os autores lançam mão armar ou construir uma novela particular. U. ECO, em seu estudo: "As formas do conteúdon(28) aborda especificamente, este tema.

Em nosso caso, a "matéria do conteúdo" é composta pelo que acreditamos ser a temática ligada ao medicamento. A situaçăo aqui, portanto, é diferente porque não se tem, previamente, como na televisão brasileira (e também no teatro, no cinema, etc.), um gênero ou tipo de conteúdo já estabelecido. O que se tem 
aqui såo conterudos, temas, fragilmente entrelaçados, em uma palavra, uma materia prima ou matéria do conteúdo em estado mais bruto.

O que se objetiva entāo neste momento, com a criação, neste trabalho, desta matéria do conteúdo inicial e, através dela, obter-se uma fonte de temas para a confecção de hipóteses sobre o sentido do medicamento.

Com as hipoteses testadas, em trabalhos posteriores, obter-se-á matéria do conteúdo mais refinada, ou seja, temática mais específica, que permitirá melhor definição dos contornos deste meio ambiente ideológico, ou campo dinâmico de sentido, ligado ao medicamento e, por extensão, à saúde nas sociedades de consumo contemporâneas. 
III.3 - Cura e controle: eficiência e efícácia simbólica 
depoimento c) :

$(P)$ - "O que o remédio significa na sua vida?"

$(R)$ - "O que significa na minha vida

$(P)-" E$

$(R)$ - "Daqui para frente se eu encontrasse alguém que me falasse: você sarou? Talvez eu tenha achado que ele não significa alguma coisa, mas até agora ele significou muita coisa para mim (...) Porque eu era uma pessoa de ficar um ano ou dois em casa sem sair. A única coisa que eu tinha vontade (era) de chorar, . me trancar no quarto e nāo encontrar mais ninguém (...).

Então o tempo que eu comecei a usar o remédio, o Clorana, primeiro o Diuran e depois o Clorana, o Tensil... eu comecei a me sentir bem e hoje eu tenho medo de ficar sem tomar (...).

Eu prefiro... eu quero ficar sem a comida do que sem o

remédio..."

Vemos,- por este depoimento que o remédio está associado a um desejo ou fantasia de cura, em contraposição ao controle.

A primeira associação que veio à mente deste paciente quando inquirido sobre o significado do remédio foi a ideia de cura:

"O que significa na minha vida? ...se eu encontrasse alguém que me falasse: você sarou? Talvez eu tenha achado que ele não significa alguma coisa ..." 
E evidente que com a cura $o$ individuo deixa de ser doente, ou seja, a doença desaparece do organismo do indivíduo e da sua vida.

$\mathrm{Na}$ cura, o medicamento representa a saúde definitiva, o que lhe confere um alto grau de eficiência e eficácia simbolicas.

Eficácia simbólica é então o "resultado" do símbolo, a prova de que o significado do medicamento é, mesmo, igual a" Saúde". Eficiência simbolica diz respeito ao processo de obtenção da saúde.

Quando há cura, há saúde definitiva, o que significa alto grau de eficiência simbólica: a utilizaçao do meio, do instrumento, levou ao fim desejado, de uma vez por todas

Em contraposiçāo, com o controle, a saúde tem que ser permanentemente re-obtida, o que significa baixo grau de eficiência simbólica.

Com o controle, efetuado pelo medicamento (entre outros recursos) o indivíduo não deixa de ser doente: ele deixa de estar doente, de ficar doente:

depoimento a) :

Mas também eu estou com aquele calor, aquela ansiedade ... eu tomo o Aldomet é a mesma coisa que tirar. Quando vai passando o efeito outra vez..." 
No caso do controle, entåo, a eficiência simboblica do medicamento é menor. Com efeito, deixar de ser doente é algo que se consegue com o consumo, por um determinado período, do medicamento. Já para deixar de estar doente é necessário, em situaçóes crônicas, consumir, em caráter permanente, o medicamento.

Mas, a despeito desta diferença na eficienncia, a eficácia simb6́lica do medicamento parece,à primeira vista, ser equivalente, na cura e no controle.

Com efeito, a cura produz um indivíduo saudável e o indivíduo saudável é um ser sem limitações.

Ocorre que o controle também produz indivíduos que, apesar de permanecerem doentes, não apresentam limitações maiores:

depoimento $h$ ):

(P) - "O que ele faz (o medicamento)?"

(R) - "...um bem estar, um bem estar, uma disposição para

o trabalho, né ..."

depoimento a):

(P) - "O que é mais importante para a sra, o médico ou o medicamento? 
(R) - "...Eu só passo no médico para pegar a receita. Porque eu não tenho outro problema. Eu tenho todas as funçōes normais, não tenho menstruçāo mas não é porisso que me falta alguma coisa.. não tenho problemas de sexo, não tenho nada que me prejudica assim, a nāo ser a pressão alta, só..."

Mas se a eficácia simbólica parece ser equivalente,o controle pelo medicamento $\epsilon$, simbolicamente mais custoso. Implica em adotar o medicamento como quem $\varepsilon$ compelido a adotar um hábito, ou até mesmo um vício, implica em aceitar o medicamento com resignação:

depoimento c) :

(P) - "Como é para a senhora ter que tomar remédio a vida toda para controlar a hipertensão:

$(R)$ - Eu sei que eu tenho que tomar mesmo e me coloco na cabeça que pode de repente pode me acontecer uma coisa nuim, né(...). Então eu encaro isso assim como uma coisa que, antes eu tinha esperança que um dia eu nāo ia mais tomar, mas aí eu volto ao médico e ele diz que tem que tomar, tem que tomar, então encerrou ... encerrou agora a palavra: "agora eu vou deixar". Agora eu vou continuar.

(P) - "Para sempre?"

(R) - ...é...porque não tem outro jeito. Fazer o que .... Agora, eu gostaria se eu chegasse um dia, lá, um dia, no médico ele falasse assim: ó, você não precisa mais tomar. Mas não...".

E interessante observar - considerando que este depoimento $\varepsilon$ da mesma depoente do primeiro depoimento - que, a despeito dela afirmar: "ele (o remédio) significou muita coisa para mim... eu comecei a me sentir 
bem... eu quero ficar sem a comida do que sem o remédio... "coloca, mais adiante: "Agora, eu gostaria .... se o médico falasse assim: 6 vocé não precisa mais tomar... mas não."

Fica bastante claro entáo, neste depoimento,que o desejo de eficiência simbólica do medicamento (o desejo que ele seja um instrumento potente, forte,definitivamente resolutivo )e a frustração pela não realização do desejo, coexiste com o reconhecimento da sua capacidade de produzir estados de saúde. Mas estados de saúde não são, simbolicamente, a mesma coisa que seres saudáveis.

Daí podermos avancar a idéia de que também e eficácia simbólica do medicamento que controla é menor do que a do que cura.Isto decorre da sua incapacidade de eliminar o Ser doente; implica em aceitar, resignadamente, a ideia de conviver com este Ser doente, que não pode ser eliminado, já que o máximo que o medicamento pode fazer é contribuir para a reprodução permanente de um Estar saudável. 
III.4 - 0 medicamento, ambigüidade e moral 
depoimento j) :

(P) - Mas se a sra pudesse escolher, digamos...que a gente deixasse a sra escolher. Falar assim, o: a sra. escolhe: ou faz o regime ou toma o remédio. A sra escolheria o que?

(R) - Não, eu escolheria o regime assim, porque a gente sente melhor.

(P) - Ah, é, e como é esse sentir melhor?

$(R)$ - Nāo, porque... se for regime assim para nāo engoradar muito, por exemplo, para a gente se sentir ... Por exemplo, o meu corpo, se eu engordar mais do que estou aqui ... tudo o que eu faço sai cansado, me sinto mais cansada entäo eu acho que a gente se sente mais assim, fica mais gorda, parece que a pressão, parece que não volta ao rítmo certo.

(P) - E o remédio?

(R) - O remédio... sei lá: todo dia tomar aquele remédio, todo dia tomar remédio, então...

(P) - Porque a sra não gosta de todo dia tomar remédio?

$(R)$ - Não, se eles mandam tomar a gente toma, né?

(P) - Mas a sra. não gosta, né?

(R) - Nāo, eu gosto de tomar. Mas se eu achasse um jeito de não tomar o remédio...

(P) - Porque então seria melhor a sra não tomar o remédio?

$(R)$ - Porque se a gente... não precisasse tomar o remédio melhor era.

(P) - Porque era melhor?

(R) - Ah, eu não sei explicar.

(P) - O que o remédio significa na sua vida?

(R) - É, significa melhora, né? 
(P) - Significa melhora?

$(R)$ - Porque se a gente toma o remédio que ele passa, se ele passou aquele remédio, a gente tem que tomar, que sabe que é para o bem da gente, né, então...

(P) - E se não tomar, o que acontece?

(R) - Se eu não tomar é pior para mim, né?

(P) - O que acontece com a sra?

$(R) \cdot$ Ah, me sinto mal, né?

(P) - Só isso?

(R) - É, porque se ele marcou aquele remédio a gente tem

que tomar.

(P) - E se não tomar, o que acontece?

(R) - É ruim para a gente.

$(P)$ - O que é esse ruim?

$(R)$ - Ah, a gente se sente mal, passa mal.. a pressão: se a gente não tomar o remédio é pior para mim, eu me sinto mal.

(P) - E o que é para a sra ter que tomar remédio a vida inteira?

(R) - Isso ai eu diria que é um castigo.

$(P)$ - A sra se sente castigada?

(R) - Não, porque se a pessoa tem que tomar aquele remédio a vida inteira... para viver tem que ser um pouco sofrimento, né?

(P) - E a sra acha que vai precisar tomar remédio a vida inteira?

(R) - Ah eu não sei Não sei te responder.

$(P)$ - Não tem ideia? E se tivesse que tomar a vida inteira?

(R) - Ah, tomava, né?

(P) - Porque? 
(R) - Porque a gente, por exemplo, tem que seguir o mais, que a gente vai no médico, a gente tem que seguir o que ele fala porque ele sabe mais do que a gente, então a gente tem que seguir o que eles mandam.

$(P)$ - E se não seguir, o que acontece?

(R) - Acontece a piora da gente, né?"

O depoimento analisado revela, com clareza, um aspecto relevante da ambiguidade do medicamento com o símbolo: o medicamento é um pilula amarga que, no entanto, deve ser engolida porque é para o bem do paciente.

E interessante observar o depoimento em detalhe. Nesse sentido, o primeiro a se notar é que quando se sugere a possibilidade de optar entre o regime alimentar e o o medicamento, a depoente opta pelo regime e justifica positivamente a sua escolha.

Mas, na oposição que estabelece entre o regime alimentar e o medicamento, se a depoente, por um lado, consegue alinhar as qualidades positivas do regime, por outro, não consegue descrever os atributos negativos do medicamento.

Começa por envolve-lo numa tonalidade ou clima negativo:

"O remédio... sei lá, todo dia, tomar aquele remédio, todo dia tomar remédio, então..."

Em seguida, quando colocada diante da necessidade de justificar porque não gosta do medicamento, na primeira resposta não apenas não consegue explicitar o seu não gostar como procura, veladamente, negá-lo: 
"Não, se eles mandam tomar, a gente toma."

Ou seja, se o seu não gostar não é negado, explicitamente, é colocado como irrelevante em relação à obrigação: "se eles mandam tomar..."

Colocada novamente diante da necessidade de reafirmar . o seu não gostar, a depoente termina por negá-lo,explicitamente:

$$
\begin{aligned}
& \text { "(P) - Mas a sra não gosta, né? } \\
& (R) \text { - Não, eu gosto de tomar." }
\end{aligned}
$$

Ou seja, a depoente incorpora de tal forma a obrigação que esta transmuta-se num gostar. A despeito disso, deixa implícito que seria melhor se houvesse um jeito de não tomar o medicamento.

Instada, finalmente, a justificar porque seria melhor nāo tomar o medicamento, não sabe explicar.

É interessante, então, procurar entender os fundamentos desta incapacidade.

Nesse sentido, o que se pode avancar é que esta incapacidade pode estar ligada ao fato do medicamento ter um componente mau que lhe é inerente, que portanto, não necessita de explicação. Esta inerência, sinal revelador da força antropológica deste componente negativo, é aquela revelada por expressões clássicas relativas ao medicamento tais como: pilula amarga; dourar a pilula, a interjeiçāo: droga! (que se contrapōe, também em nível antropológico, as forças positivas relevadas por expressões como "santo remédio", "pomada milagrosa"). 
Continuando a análise do depoimento, na linha de buscar descrever, atraves dele, a ambiguidade do medicamento como símbolo, temos que, quando inquirida sobre o que significa o remedio em sua vida, a depoente responde inicialmente: "significa melhora". Mas analisando a sequência do depoimento verificase claramente que o que se entende por melhora nåo $\mathcal{E}$ uma melhora fisica mas uma melhora moral.

Com efeito, quando instada a explicitar ou reafirmar a

ideia de melhora...

"(P) - Significa melhora?

...a depoente responde:

(R) - Porque se a gente toma o remédio que ele (o médico) passa; se ele passou aquele remédio, a gente tem que tomar, que sabe que é para o bem da gente."

O remédio $\epsilon$, portanto, uma obrigação e na obrigação está contida a pilula amarga que a depoente refere implicitamente. E, além disso, quando tomar o remédio está associado à expressão para o bem da gente, este remédio está também automaticamente associado a algo mau, porque na significação codificada da expressão para o bem da gente (ou para o seu bem) está implícito que aquilo que é para o bem da gente é algo mau (ou amargo, ou difícil).

A despeito de eventuais referências a sensaçōes ("a gente se sente mal", " passa mal", "eu me sinto mal") que, no entanto não tem a concretude ydos sintomas, o depoimento segue colocando o medicamento num contexto geral de significaçōes morais marcadas por obrigações ("se ele marcou aquele remédio a gente tem que tomar") e por punições ("se a gente nāo tomar o remédio é pior para mim..."). 
Ainda mais moral/puniçáo:

"P) - E o que é para a sra. ter que tomar remédio a vida inteira?

(R) - Isso eu diria que era um castigo."

O contexto moral fecha-se, finalmente, com a justificativa maior para a obediência, para o cumprimento da palavra médica: o saber:

"... a gente tem que seguir o que ele fala, porque ele sabe mais do que a gente, então a gente tem que seguir o que eles mandam."

Em síntese, o medicamento é um símbolo, que colocado num contexto de valores morais, de que a nossa cultura está impregnada, pode ser entendido como implicando a ambiguidade contida na expressão: males que vem para bem. 
III.5 - O medicamento como símbolo ambiguo e o deficiente químico 
Uma das consequências do medicamento ser - como cremos- uma prótese química é que esta prótese pode despertar, no usuário de medicamentos (sobretudo quando se trata de usuários permanentes, como os hipertensos), um sentimento mais ou menos vago, de inclusăo na categoria dos deficientes. Podemos chamar a este tipo de deficiente de deficiente químico para indicar que pertence, como os "f́́sicos", a categoria dos deficientes, mas que constitui uma sub categoria a parte, a dos "químicos".

Como o deficiente físico que não consegue andar sem o auxflio de muletas, o deficiente químico não consegue, por exemplo, manter a pressão normo tensa sem o auxflio de um medicamento antihipertensivo. $O$ medicamento antihipertensivo é, portanto, o equivalente químico destas muletas. E, portanto, um símbolo ambíguo: por um lado representa a saúde, por outro lado, a doença.

depoimento a) :

"Eu perdi** minha saúde (natural). De lá para cá, é tomar remédio (saúde artificial). Remédio forte: eu tomo três comprimidos por dia para a pressão, dois Aldomet 500 e um Propranolol 80".

A depoente associa diretamente a perda da sua saude original como a fatalidade (o $e$ ) de ter que tomar remédio. Ou seja, uma vez perdida a saúde original... é tomar remédio (a saúde artificial). O que ficou no lugar da saúde original perdida é a saúde artificial, ou seja, o medicamento. Mas...

"(A pressão alta) é uma coisa que convive comigo. Eu já acostumei. (Tomar medicamentos) tornou-se um hábito. É que nem tomar café,

\footnotetext{
- O deficiente químico pode tamberm ser visto, por contraste com o físico, como um deficiente interno.

** Assim como o deficiente físico perdeu a movimentação de um membro. A idéia de perda 6 fundamental para caracterizar a deficiência.
}

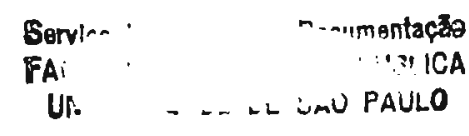


almoçar, jantar. $E$ como as mulheres no ciclo menstrual: tem que tomar anticoncepcional. Eu não tomo anticoncepcionah tomo Aldomet. Mas ele me faz bem."

Portanto, tomar medicamentos tornou-se um fato do dia a dia, como tomar anticoncepcional e que lhe faz bem, lhe produz bem estar, ou seja, Saúde, mas ...

(P) - "Como é para a senhora ter que tomar remédio a vida toda para controlar a hipertensão?"

(R) - Olha, para mim que casei com 38 anos, tenho 3 filhos pequenos, eu até acho uma boa ter uma coisa que resolva, por enquanto. Que ajuda a levar um pouco adiante, porque, quando nada, é uma perspectiva de vida, né. Eu tomo o remédio, eu me sinto bem, quer dizer, é um círculo vicioso, não posso ficar sem ele..."

Em uma palavra, a ambiguidade que o medicamento representa para o deficiente químico advém do fato de que ele indica, ou significa, ao mesmo tempo, o preenchimento de algo que falta ao deficiente (ou seja, a saúde perdida) e o fato mesmo de algo lhe falta (ou seja, a deficiência).

Lembremo-nos que na definição pierceana de símbolo este aparece como algo que está por outra coisa, ou em lugar de outra coisa, para alguém. Nesse sentido é importante contrastar o deficiente físico com o químico porque o medicamento anti hipertensivo, como símbolo, está no lugar da saúde perdida, sobretudo para ele, deficiente químico, o que o diferencia do deficiente físico, para o qual a muleta está no lugar da mobilidade perdida do membro, para o deficiente e para os outros, que o veem permanentemente com a muleta, o que não acontece com o deficiente químico, que pode esconder ou portar "secretamente", ou privadamente, ou discretamente o símbolo da sua deficiência, ou seja, o medicamento. 
III.6 - O medicamento e a hipertensão como doença e năo doença 
depoimento L ):

(P) - "O problema da hipertensão ...o que que a sra imagina que é essa doença, como é isso para a sra?

(R) - Não sei o que quer dizer isso. Eu sei, que escuto falar . ...que se a pressāo sobe muito, que pode dar um derrame, que pode dar um ataque, tudo isso. Agora, se souber levar o regime para controlar. Que é doença e não é doença. Agora, eu não sei que é; eu nāo sei.

(P) - Por que nāo é doença?

(R) - Quer dizer, é doença porque se a gente não controla pode subir a pressão muito, pode dar um derrame, pode até matar. Agora, se a gente leva para o outro lado, que, como diz o outro, como a gente deve levar, tomando, ou toma o remédio ou controla a pressāo... minha pressão sobe muito quando eu me aborreço... que se eu me aborreço, fico chateada, assim minha pressão sobe.

(P) - Como é que a sra. sabe?

(R) - Porque sinto tontura, da dor de cabeça também. $A h$, eu esqueci de falar que me dava dor de cabeça...".

A hipertensão é e não é uma doença. É uma doença, porque pode "até matar", se não controlada. Controlada, ela se transforma num estado normal. Doença, portanto, é sinônimo de ameaça grave à integridade do organismo.

A hipertensāo é uma doença na medida em que é uma ameaça grave. Mas esta ameaça não é direta. Não se está na mesma situação, por exemplo, de um réfem ameaçado de levar um tiro na cabeça caso a polícia resolva investir contra o criminoso, que o fez réfem. A ameaça, ou seja, invalidez e a morte . (e portanto a hipertensāo como doença) está aqui associada a sintomas leves e cotidianos (dor de cabeça e tontura) dos quais constitue um desdobramento já... 
"...que eu escuto falar, vejo as pessoas tudo que se a pressão sobe muito... pode até matar".

Ocorre que, para o depoente, a pressão, efetivamente,"sobe muito". Com efeito, os sintomas da pressão alta (tonturas, dores de cabeça) se encontram, no seu organismo, em nível superficial de latencia, podendo . emergir com relativa facilidade à superfície:

"Minha pressão sobe muito quando eu me aborreço.

(P) - Como é que a sra. sabe?

(R) - Porque eu sinto tontura, me dá dor de cabeça

também..."

A pressão alta, tem, pois, para o depoente, uma existência concreta, cotidiana, na medida em que está representada por coisas reais, sentidas no dia a dia ("minha pressāo sobe muito quando eu me aborreço") como a dor de cabeça e a tontura.

Estas coisas concretas são, por sua vez, símbolos (ou, mais precisamente, simbolizantes) vagos, ou indícios de morte ou invalidez na medida em que acrescentam um certo grau de concretude, de "dentro" (do organismo) à ameça de morte que vem de "fora" (da ciência, do médico, do que "se escuta falar").

Confrontemos duas situações possíveis. Na primeira, o médico (ou o educador em saude) coloca para o paciente hipertenso que o nāo controle da sua pressão pode leva-lo à morte. Mas este paciente nāo sente nada. Neste caso, a ameaça de morte não tem representante endógeno (ao indivíduo). A ameaça está totalmente vinculada a situações externas a este indivíduo tais como: 
crença na santoridade do médico em geral e/ou crença na autoridade de algum médico particular, conhecimento de algum caso de hipertenso que não controlava a pressăo e morreu precocemente, etc.

Numa segunda situação, a advertencia do médico ou do educador em saúde corre paralela à existencia de dores de cabeça e tonturas que o paciente toına como significante de hipertensão. Nesse caso o paciente pode fazer uma associş̧āo entre hipertensăo e morte ou invalidez porque a hipertenção existe, concretamente, no dia a dia, na forma de dores de cabeça e tonturas, associadas a aborrecimentos.

Para o paciente em tela, a morte (e a doença) existem, portanto, numa certa medida, na vida do dia a dia. A morte ocupa um espaço (o corpo do paciente como locus da dor de cabeça e da tontura) e um tempo (o cotidiano dos aborrecimentos).

Este paciente é, para si mesmo, um doente porque a doença tem uma representação, mesmo que indireta, endogena. Para outros pacientes (ser,por exemplo,III.10.) a doença não existe, neles, porque ela não tem qualquer tipo de representação endogena, ou seja não ocorre num espaço e num tempo pertencentes a estes individuos. Estes entāo não são doentes para Si mas para o Outro (a sociedade, o médico).

O controle da hipertensāo, pelo medicamento, controla, neste caso, duas coisas: diretamente, o manifesto e indiretamente o latente. $O$ controle do manifesto permite o transcorrer normal da vida, eliminando a dor de cabeça e a tontura. E o medicamento como anti sintoma, anti dor de cabeça, a anti tontura, é a saúde no dia a dia. Ao mesmo tempo, o medicamento elimina a morte e 
III.7 - O medicamento e o controle da vida X controle da doença 
a invalidez. É o medicamento como anti doença, ou seja, é a saúde na escala da vida como um todo.

O remédio portanto, para os pacientes que têm sintomas, elimina a morte como concretude (ou, o que dá no mesmo, a ameaça concreta de morte) ou seja, a morte que está, concretamente, na dor de cabeça e na tontura como sensaçōes. Nesse caso, o remédio representa, também concretamente, a vida na medida em que esta vida representada é a eliminaçăo da morte como concretude.

Já, para os pacientes, que nāo tem sintomas, o remédio é uma abstraçāo: representa a vida, ou a eliminação da morte-ambos os dois meros conceitos sem representaçâo endógena, ou motivada, ou subjetiva (Ver TODOROF (76) - através de um código arbitrário, ou seja, através da Lei do Outro - do médico, da sociedade.(v.III.10.) 
depoimento L) :

(P) - "...quando a sra. toma o remédio não dá dor de cabeça?

(R) - Não. Se eu tomar assim, se eu tiver assim a pressão que eu acho que a pressão - eu não sei se é pensamento da gente que a pressão está mesmo - se a minha cabeça começa a doer um pouquinho, pode tirar a pressão que está sempre alta.

(P) - Ah, oh! e ela tem ficado, mesmo quando a sra. toma o remédio?

(R) Não, só se eu... ficasse assim as vezes um dia sem tomar que, como é metade cada segundo dia, às vezes posso até esquecer, eu esqueço de tudo. Mas aí, se eu comer comida assim,como eu vou falar, como eu ia dizer...

(P) - ...muito temperada?

(R) - É, é, linguiça, vá... E linguiça já que é meio ardida, então quer dizer que aí mesmo que se eu, como assim, que me faz mal (não é que me faz mal, é que eu sei que a pressão me sobe mais um pouco) então, para controlar, então ai eu, às vezes, sei que eu vou num churrasco, assim que a minha irmã de vez em quando faz, eu como um pedaço de linguiça assim, aí então eu já tomo o remédio, assim, dois dias seguidos, metade cada dia. Hoje é dia de tomar, nós vamos ao churrasco, então eu tomo hoje. Mas amanhã eu não devia tomar então eu tomo... porque eu comi a linguiça hoje. Eu não sei se estou certa(...) porque aí eu como um pedaço de linguiça, porque os outros comem então a gente come... e a sardinha, pōe aquele sal grosso assim. A gente faz assim estas churrascadas... e a gente vai comer sardinha, assim, dai eu controlo, assim com o remédio.

(P) - Esse controle que a sra faz com o remédio, como é que a sra tem idéia, porque a sra lembrou do remédio na hora de comer estas coisas? 
(R). Al, se é para ficor doente eu tomo o remédio que é para nao ficar. Ai eu podia ter dor de cabeça ou minha pressa ficar muito alta, assim,

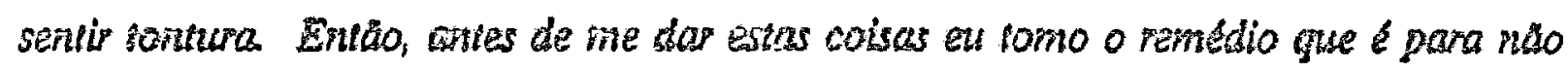
dar."

O médico controla uma pressåo, o paciente, a sua vida. Portanto, o medicamento, assume sentido distinto para cada um destes atores. A hipertensáo, para o médico, é um valor numérico (que é um símbolo, ou . representante, ou expressăo, na cultura médica, da hipertensão). Esta se inscreve, para o médico, na perspectiva temporal da consulta e no espaço do onganismo alheio como suporte de uma pressão.

Para o paciente, a hipertensăo é representada, simbolizada, expressada, sobretudo por um sintoma, por uma sensação corporal, que se inscreve na temporalidade de dia a dia do paciente e no espaço do seu organismo como suporte desta sensação.

Para o médico há uma doença (a hipertensão) a ser controlada; para o paciente existẹ um doente a ser controlado. A doença nāo come . linguiça, o doente, sim.

A quantidade de medicamento, para o médico, é função do controle periódico da pressão; a quantidade de medicamento, para o paciente, $\epsilon$ função do controle permanente dos sintomas.

Eticamente falando, dependendo do sujeito do controle, temos uma situação de beteronomia ou de autonomia. Para a medicina, a beteronomia $\varepsilon$ a regra. $O$ auto controle, estritamente falando, implica no sujeito institucional: paciente, assumir efetivamente o controle da sua doença, o que 
configura (do ponto de vista médico) uma conduta desviante.

Numa situaçăo de doença crônica, como a hipertensáo, o paciente é sempre, aquele que efetua o controle, através do medicamento. Mas isto nem sempre, evidentemente, configura uma situação de auto congrole: com efeito, se o paciente limita-se a efetuar a determinação médica, a situaçāo permanece como de hétero controle, tendo o paciente um papel de mero agente passivo deste controle, sem nenhuma autonomia decisória.

O auto controle, strictu sensu, implica na apropriação indébita de si mesmo, já que o paciente, na nossa sociedade e na nossa cultura, não tem "de jure" (de fato é um outro problema) a posse de seu corpo doente. Com efeito, na medida em que o Corpo ficou doente ele nāo mais pertence ao seu dono, que é compelido a entregar a gerência deste corpo ao Sujeito Institucional-Legal dos Corpos Doentes, ou seja, o médico.

Quando o paciente hipertenso não apresenta sintomas, o hétero controle através do medicamento tem uma certa lógica. Isto porque este paciente nāo tem objeto próprio de controle, não tem o que controlar, já que a pressão que não se traduz por sintomas não é seu objeto mas objeto do médico. Nesse caso, o controle nāo lhe pertence; quem está controlando (a hipertensão e não o hipertenso) é o médico, do qual o paciente é uma mera extensão: quem leva à boca, diariamente, o comprimido é, apenas aparentemente, a mão do paciente. Na realidade esta mão é a mão do médico, que o paciente internalizou.

Já quando o paciente hipertenso tem objeto próprio de controle (sintomas, sensações) ele está mais apto a ser sujeito do controle da sua • doença, através do medicamento. 
E o depoimento acima apresentado sugere que os pacientes assumem, através do medicamento, o controle (entre aspas para a medicina) da sua hipertensáo:

"Hoje é dia de tomar, nós vamos ao churrasco, então eu tomo hoje. Mas amanhã eu não devia tomar então eu tomo... porque eu comi a linguiça . hoje. Eu não sei se estou certa, se estou errada... A gente faz assim estas churrascadas... $e$ a gente vai comer as coisas, assim, come um pedacinho de linguiça, come sardinha, assim, dai eu controlo, assim, com o remédio."

O significado ou simbolizado do símbolo: medicamento, é diferente, portanto, caso seja o indivíduo ou o médico o sujeito do discurso e da ação de controle da doença através do medicamento. Para o indivíduo, neste contexto, o simbolizado do medicamento é o que poderíamos chamar de "saúde leiga"; para o médico, o simbolizado é o que poderíamos chamar de "saúde médica".

E obvio que muitos pacientes adotam, para $o$. medicamento, o seu significado médico. Nesse caso, deixam de ser sujeitos do discurso e da ação frente à sua doença: quem fala e age por eles é o médico (ver III.10 ). Estes são, em geral, considerados como "bons pacientes". 
III.8 - O medicamento como símbolo de saúde e doença 
Caberia, do ponto de vista que é o deste trabalho, ou seja, do ponto de vista da análise do medicamento como mercadoria simbólica, investigar . as implicaçóes do fato deste possuir tambem, de acordo com os pacientes hipertensos, um lado "mau", uma dimensăo "doença", um lado "endiabrado" que coexiste, em conflito, com seu lado "santo" de "santo remédio".

O medicamento para o paciente crônico é um símbolo que traz no seu cerne a ambiguidade ou seja, a saúde e a doença, na medida em que $\varepsilon$, de um lado, a lembrança permanente, para o paciente, da sua condição de doente, a presença de uma falta, uma prótese química, e de outro lado a garantia da continuidade da vida, da não morte, da não dor, do não incómodo, enfim, do silêncio da doença:

\section{Depoimento f):}

"Porque o remédio também qu gente sempre ouve falar que ele traz efeitos colaterais. Isto é um problema que assusta.. No caso do Higroton, por exemplo, a gente ouve falar que ele elimina o potássio do corpo. Entāo tem que comer muita banana, chupar muita laranja".

\section{Depoimento a):}

"Porque o remédio, a tendência dele é fazer mal para alguma coisa. Até hoje eu não percebi que ele me faça mal para nada. Porque todas as pessoas dizem: porque o Aldomet faz isto para mim, faz aquilo. Em mim só faz bem."

As expressōes destacadas: "a gente sempre ouve falar" (que o remédio traz efeitos colaterais), "a gente ouve falar" (que ele elimina o potassio); "a tendência dele é fazer mal"; "todas as pessoas dizem" (que o Aldomet faz 
mal) săo marcas, traços, no discurso dos indivíduos, da presença de uma sentimento coletivo, de carater negativo, que faz parte do sentido do medicamento na nossa cultura.

Nåo basta, é claro, constatar. É necessário procurar entender a razāo desta ambiguidade constatada do medicamento.

A nossa hipbtese a respeito é que esta razão tem a ver com a oposição semântica fortemente ancorada na cultura leiga sobre saúde, que contrasta o "natural" com o "artificial", êste último identificado com a "química":

depoimento d) :

"Olha, o remédio em si, a química, né, o remédio para a hipertensāo feito assim de uma química pura, eu não posso imaginar, nem pensar de tomar. Uma coisa deste tipo, eu acho assim que é para último caso(...). E, realmente, se há condiçōes de uma forma natural, sem ingerir produto químico, eu acho que é o ideal".

Este "produto químico" é também entendido, pelos pacientes hipertensos (e, cremos, pela cultura como um todo) como um "tóxicon:

Depoimento e):

(P) - "Como é que você imagina tomar remédio para a pressão alta a vida toda?

(R) - Eu imagino assim: se eu tenho que tomar e é para o meu bem, eu tomo... Agora, por exemplo, se eu pudesse evitar, se tivesse um meio assim de evitar de tomar remédio para a vida toda eu faria.

$$
\text { (P) - Por quê? }
$$


(R) - Porque eu acho que o organismo da gente fica muito

intoxicade de remédio.

Depoimento k):

(P) - "A sra estava falando de remédio, né... eu queria saber, assim, o que o remédio significa na vida da sra?

(R) - Olha, eu sou franca a dizer: se eu puder passar sem o

remédio...

(P) - Por quê?

(R) - Porque eu acho que a gente fica encharcado como.

remédio.

(P) - O que é encharcado?

(R) - A gente fica assim intoxicado assim...".

O medicamento faz parte (junto com a engenharia genética, por exemplo) de toda uma gama de símbolos ou representantes da interferência do homem (através da Ciência) sobre o organismo. Diferentemente da manipulação de elementos da natureza, que dá como resultado a fito terapia, a homeopatia, etc. o medicamento alopático implica na criação perigosa (porque criar vida é, culturalmente visto como um atributo divino) de artefatos corporais.

Os medicamentos podem então ser vistos, nesse campo de sentido, como pedaços artificiais de organismo ou de substância orgânica, que representam criações que, numa certa medida, podem ser vistas como de "aprendiz de feiticeiro".

A nosso ver, o depoimento desta paciente espelha este temor cultural com relaçāo aos efeitos das açōes de "aprendiz de feiticeiro": 
depoimento d) :

"O médico fez uma série de exames e constatou que eu tinha uma lesão, um foco de disritmia e eu precisei tomar Gardenal, Hidantal. Daí tomava um remédio para dormir e um para acordar... esse tipo de coisa assim, calmante, porque eu ficava nenosa e eu senti que fiquei assim uma pessoa completamente diferente, com outra personalidade, tomando essa medicação...".

A saúde artificial simbolizada no medicamento "químico" ou "tóxico" remete à oposição semântica, presente na nossa cultura, entre "dentro" e · "fora", em que "dentro" significa dentro da ordem natural, dentro da natureza, dentro de Deus (não é por acaso que a Igreja Católica prega os métodos "naturais" - que é o mesmo que dizer "divinos" na medida em que Deus é criador da natureza - de controle da natalidade) e "fora" significa fora da natureza, ou seja, dentro da Ciência enquanto manifestação do "materialismo", ou seja ainda, dentro da "ordem artificial".

Parece claro que, neste contexto, o médico, na qualidade de fiador da eficácia do símbolo medicamento, na medida em que deixou de ser, como o pajé e o curandeiro, um intermediário entre Deus, a Natureza e os homens, está no interior do campo semântico - cultural do "fora".

Isto nāo pode deixar de ter certas implicaçōes, uma delas a de que a ciência e o cientista materialistas e, conseqüentemente, o consumo de seus produtos como o medicamento, saem do campo das "forças superiores" para entrar no campo do livre arbítrio, dos juizos terrenos, da falibilidade, da crítica.

Isto dá lugar a (ou permite o surgimento de) uma série de oposições que afetam o médico, o medicamento e o paciente tais como: depender $\mathrm{X}$ 
năo depender do medicamento: controlar $\mathrm{X}$ náo controlar a enfermidade; acatar $\mathrm{X}$ nåo acatar as ordens médicas.

A ambiguidade do simbolo medicamento (o fato dele representar, no mundo do paciente, ao mesmo tempo, saúde e doença, bem e mal, cura e intoxicação) permite que o paciente preserve uma parcela do controle sobre o seu processo de saúde - doença no que toca ao medicamento:

Depoimento b):

"Como eu sei que este remédio, ele faz a gente urinar muito, quando eu estou boa, às vezes eu passo uns dias que não tomo. Até o doutor mesmo falou: pode passar um dia. Mas eu passo até dois, tres dias que não tomo. Às vezes eu passo. E nāo sinto diferença nenhuma".

Depoimento e):

"E também não gosto de tomar remédio para dormir".

(P) - Por-quê?

(R) - Ah, eu tenho medo de tomar, sabe. Não tomo mesmo! Eu prefiro deitar mais cedo, acordar alí pelas quatro horas, então eu fico na cama até umas seis horas mas não tomo remédio. Já me passaram remédio para dormir mas eu nāo tomo.

(P) - Por quê?

(R) - Porque me dá uma vontade de chorar tremenda, sabe.

Então eu acho...Eu tentei tomar mas ai eu vi que não era bom para mim.

(P) - Quem passou o remédio para você.

(R) - Foi o Dr....E depois eu voltei lá e falei com ele que eu

não iria tomar o remédio. 
(P) - E você explicou?

(R) - Expliquei.

(P) - E ele?.

(R) - Ele falou que tudo bem."

O remédio, neste caso, é um símbolo ambíguo porque faz dormir, e fazer dormir indica o poder da "ordem artificial" da "ordem médica"; mas, ao mesmo tempo, faz chorar, o que revela que esta ordem artificial envolve um componente de "desordem".

Este componente de desordem é sentido pelo paciente, pelo indivíduo, pelo leigo e mobiliza nele, dialéticamente, uma "contra ordem" um "contra poder":

"Eu tentei tomar mas aí vi que não era bom para mim".

O medicamento aparece, no mundo do paciente, como um símbolo, mas frágil, ou mais precisamente, fragilizável, porque pertencente a uma "ordem artificial" a ordem dos seres humanos, ordem esta contestável, em princípio porque seus membros bem como os ditames destes perderam o característico anterior de representar, no campo da saúde, uma vontade superior, permitindo assim, pelo menos virtualmente, a divergência já que o terreno do embate situa-se agora totalmente na terra.

E vale notar que este paciente que sabe "o que não era bom para mim" é uma empregada doméstica,ou seja, alguém duplamente "inabilitado" -pela sociedade por ser socialmente subalterno e pela medicina por ser um mero paciente - para saber o que é bom para ele 
III.9 - O medicamento e a necessidade 
O paciente crônico deve consumir cronicamente 0 medicamento. É preciso portanto que esta ingestáo crônica do medicamento perfaça am sentido para o indivíduo. Posto que o medicamento é uma mercadoria, este sentido pode se expressar sob a forma de necessidade, que a mercadoria medicamento deve satisfazer.

Alguns pacientes passam então a viver a hipertensāo como mecessidade e consequentemente o uso do medicamento para o enfrentamento de uma condição - a pressão alta - transforma-se em uso do medicamento para o enfrentamento de uma situaçāo, ou seja, dos sintomas, ou do que os pacientes creem ser os sintomas, da pressāo alta: tonturas, náuseas, enjoos, inchaço, nervosismo.

\section{Depoimento a):}

"Às vezes acontece como agora, por exemplo, esse calor, estou suando, a transpiração, calor, um pouco de tontura, enjoo. Entāo eu fico com aquele enjoo, aquele enjoo. Em vez de tomar o remédio para o estômago eu tomo o da pressāo. E é exatamente o que sara. Ela se manifesta como enjôo."

A pressão alta tornada necessidade, ou seja, pressão/enjoo, permite entender a presença do medicamento neste contexto como algo que compartilha o sentido corrente das mercadorias, ou seja, como a expressão concreta, o simbolizante da anti-necessidade ou da resposta (para utilizar o jargão sanitarista) RESOLUTIVA.

Depoimento h:

"(P) - E o que é para a sra. ter que tomar o remédio a vida inteira? 
(R) - Se fiver que tomar, a gente loma, ne, que vai fazer?

(P) - Mes como sque voce se senie em relacto a lsso?

(R) - Nă, me sinso normal, normal Que eus acho gue é uma coisa assim, como eu disse né, no lugar em que eu trabalho é uma coisa meio agitada, né. Então a gente é obrigada a tomar..."

A hipertensão, como se vê neste caso, também se manifesta através de estados de nervosismo decorrentes das condiçoes de trabalho. A paciente considera que tomar remédio a vida toda $\varepsilon$ algo normal já que "o lugar em que eu trabalho é uma coisa assim meio agitada".

O medicamento concebido - pela medicina - para ser usado no controle de uma condição crônica como a hipertensão passa então a ser usado pelo paciente no controle de uma situaçāo, o nervosismo, presente na rotina do dia a dia do trabalho do escritório (a depoente trabalha num escritorio).

Depoimento e):

"(P) - Como é para você tomar o remédio e nāo sentir nada. Você nāo sente nada e toma o remédio?

(R) - Não, por exemplo assim o meu organismo, assim um dois dias ou tres eu não percebo que altera. Agora eu tenho a impressão que se passar mais do que isso a pressão sobe.

(P) - Se passar mais você acha que sobe?

(R) - Eu acho que sobe.

(P) - Como você sente?

(R) - Ah, porque eu sinto assim mais cansada, dá batedeira.

$(P)$ - Você já teve isso, de ficar cansada, com batedeira?

(R) $-J \dot{a}, j a ́$ 
(P) - E neste tempo vocé estava deixando de tomar o

remédio?

(R) - Eu passei uns quatro dias sem tomar.

(P) - E dai, você sentiu isso?

(R) - Eu senti.

(P) - E daí você tomou o remédio.

(R) - Tomei.

(P) - E dá̛ você melhorou.

(R) - Melhorei."

Depoimento c):

"(P) - Você já deixou um tempo grande de tomar o Clorana (diurético anti hipertensivo)?

(R) - Eu deixei... quatro dias só.

(P) - Aconteceu alguma coisa contigo?

(R) - Eu fui ao médico a pressão estava boa. Eu fiquei quatro dias sem tomar, quando eu voltei a pressão estava alta. Ai eu nunca deixei, tenho medo.

(P) Se a sua pressão fica alta, o que acontece?

(R) - Se ela fica alta.. Você quer dizer, o que eu sinto ou o que pode acontecer?

(P) - O que você sente e o que pode acontecer.

(R) - Olha, eu sinto ... só a cabeça, a cabeça atrapalha, sinto a dor só...

(P) - De cabeça?

(P) - É, só dor de cabeça. Às vezes eu fico nervosa,sabe, aquele negócio, coisa ruim que você sente... E, às vezes também tem hora que eu estou assim com a pressão alta e não sinto nada Nāo tenho nada. Não tenho dor de cabeça, 
não tenho nada. E está alta.. A pressāo ela só aumenta quando chega alguém aqui, dá uma notícia ruim, ai ela aumenta, né?"

A hipertensão corresponde também, nestes casos, a uma necessidade, mas que aparece sob a forma de uma sensação má mesclada de culpa, de medo. A hipertensão corresponde então a algo que poderfamos chamar de "necessidade latente". Isto implica em entender o medicamento como um tipo de resposta especial: a prevençāo do surgimento do sintoma latente, escondido, difuso, traiçoeiro (..."tem hora que eu estou assim com a pressão alta e nao sinto nada.. ").

Temos então o "silêncio" da hipertensāo (a não ocorrência de sintomas) como resultado de um esforço dos pacientes, efetuado através do medicamento consumido permanentemente, para tornar a hipertensāo silente. O silencio da hipertensão vem, assim, do fato dela estar permanentemente amordaçada pelo medicamento.

O medicamento funciona entāo como vigia permanente da doença, renovado a cada dia. Quando o "vigia" se ausenta mais do que tres dias, a doença pode se manifestar (e esta possibilidade amedronta: "Aí eu nunca deixei, tenho medo...") sob a forma de "batedeira", cansaço, dor de cabeça, "coisa ruim", quebrando seu silêncio.

Sintetizando, poderíamos dizer que nestes casos, $0^{\circ}$ medicamento, é a mordaça da doença.

Vejamos outro depoimento: 
depoimento $\mathrm{k}$ ):

"(P) - Para que a Sra toma esse remédio?

(R) - O burinac?

$(P) \cdot E$

(R) - É pela pressão.

(P) - Mas a sra falou que não tem tomado remédio para

pressão!

(R) - Não, mas quando eu incho eu tomo! Agora, quando eu incho eu tomo. Tem dias por exemplo que eu estou com o pé inchado, eu percebo que eu estou com o rosto inchado, então eu tomo. Já falei isso para o Dr... (que atende no Centro de Saúde) também eu tomo remédio sim. Que ele falou que não precisava tomar, que a pressāo estava doze por oito, estava boa. Mas eu tomo quando percebo que estou com os pés inchados, eu percebo que sinto a mão inchada, entendeu. E eu tomo. Mas é muito difícil... agora. Ou entāo quando eu fico agitada, um pouco nervosa, entāo...

(P) - A sra. tem tomado agora, esses tempos?

(R) - Esses tempos eu tenho. Inclusive, semana passada eu tive uma agitação com meu sobrinho, ruim, né?Então a gente corre que precisa internar com polícia. Voce sabe, você fica nẹvosa com aquilo, né. Eu passei a noite quase sem dormir, de perturbação. Então eu tomei. Mas de resto...

(P) - Quem deu este remédio para a sra?

$(R)$ - Quem receitou primeiro esse remédio para mim? Foi o Dr...,pera aí, foi antes do Dr... foi o Dr... que receitou..."

A paciente toma o medicamento para a presssāo, contrariamente à opinião do médico. Para ela, então o inchaço e a agitação são sintomas de "pressāo" e, portanto, o consumo do medicamento se justifica. Para o médico nāo é necessário tomar porque a pressão está boa (doze por oito). 
Existe, para a paciente, um problema sentido (o inchaço ou a agitação) que ele acredita estar ligado a "pressáo", a despeito da opiniáo do médico.

Configuram-se, assim, perspectivas distintas, do paciente e do médico, no que concerne o medicamento.

Para o médico, o medicamento é um instrumento no tratamento da pressāo alta do paciente. Para o paciente, o medicamento $\varepsilon$ instrumento na luta corpo a corpo contra o que acredita serem sintomas de pressão alterada ou situações geradoras de alteração de pressão (por exemplo, agitaçāo).

A perspectiva do médico, em relação ao medicamento e, portanto, o sentido deste objeto, para ele, pode ser influenciado pelo fato dele ser um sujeito produtor de sentido que está lidando, de fora, com um problema que não é o cotidiano de outro alguém que sofre (segundo este alguém, de pressão) mas que diz respeito ao controle periódico da variação quantitativa da pressão de um paciente.

O indivíduo, por seu turno, pode produzir o sentido do medicamento influenciado pela sua condição social de portador de necessidades (sensaçōes, sintomas) e, portanto, de consumidor de "respostas" sob a forma de mercadorias que "resolvem" ou consomem (na acepção de "fazer desaparecer", como . coloca BAUDRILLARD (6) estas necessidades. 
III.10 - O medicamento e a saúde

como compromisso social 


\section{depoimento f):}

Veja bem, se sou hipertenso é porque me disseram que eu sou. Na verdade eu não me sinto como tal. Graças a Deus me sinto muittssimo bem. Tenho bastante disposição, uma saúde de ferro para trabalhar. É como eu digo: se sou $E$ porque me disserem que sou Na verdade não me sinto."

Ser hipertenso é sentir-se como tal. Este paciente não se sente como tal; portanto a hipertensão é uma coisa alheia, um rótulo que vem do exterior.

Mas o que é sentir? Na frase: "na verdade nāo me sinto como tal", sentir é sinônimo de considerar: "na verdade não me considero como tal". Mais o fato do entrevistado ter optado, paradigmaticamente, por sentir, em vez de considerar, não parece casual porque na frase seguinte: "graças a Deus me sinto · muitíssimo bem", sentir aparece novamente. Deste modo, podemos avançar - com base na reiteração da palavra - que este último sentir permite individualizar uma acepção específica para o sentir-se de "não me sinto como tal" de sorte que parece válido interpretar a frase: "Na verdade não me sinto como tal" usando a paráfrase: "Na verdade não sou, para mim mesmo, hipertenso, porque não sinto as sensações ou sintomas de tal doença".

Sendo a doença uma sensação, o paciente não se sente doente. Mas a despeito de nāo se sentir (para usar o pleonasmo) internamente doente, ele o é externamente.

Este mundo exterior que o rotula $\varepsilon$ exemplificado, de início, pela instituiçāo na qual o paciente trabalha. 
"Isso at ha dois anos atras, mais ou menos, foi exatamente quanto entrei na Prefeitura. No teste de admissão é que começou a haver alguns probleminhas. Fui reprovado por uma primeira vez; fui reprovado por uma segunda vez, problema da hipertensāo. Em uma terceira vez, dat, sei lá, por ajuda de Deus, das pessoas, sei lá, deu tudo certo. Entäo,inclusive através de uma conversa, eu fiz eles verem que, sei lá, eu precisava traballhar, que nada tinha a ver, era uma pessoa disposta, nunca tinha me sentido mal, nunca enfim, nunca tinha apresentado problemas relacionados a isso. E prova é que lá estou há dois anos, nāo tirei férias ainda, nunca faltei."

Ser doente é então, para este paciente, algo concreto; algo que produz consequências visíveis, algo que acarreta problemas (eu nunca tinha · apresentado problemas em relação a isso), uma interrupção no fluxo do cotidiano.

Faz parte também deste mundo exterior, locus da doença, a familia:

"E isso é um problema de familia. Já ... isso é a tal história: a gente herda as boas coisas e as coisas más também. Então meu avô era hipertenso, minha mãe é, meus tios da parte materna também são e, consequentemente eu também sou, né, porque isso vai para frente, né? Mas eu me sinto muito bem."

A hipertensão aparece, pois, para este depoente, como · uma fatalidade familiar, de modo que é possível dizer que, do seu ponto de vista, não é propriamente ele que é doente mas a sua família.

A doença continua então a ver vista, pelo depoente, como algo do "outro" (do empregador, da família) e algo abstrato porque não se traduz por qualquer tipo de sensação má (Mas eu me sinto muito bem). 
Ora, uma doença sem sintomas, uma doença do "outro" supóe um tratamento também do "outro".

Este outro é a face social do paciente; e é esta face que está doente, que deve ser tratada.

"(P) - O que significa o remédio em sua vida?

(R) - Bom, o desejo de saber que ele vai me ajudar em termos de saúde e um compromisso diário a mais, só.

$(P)$ - Não tem significado mais?

(R) - Não, é o que eu digo: o valor positivo que ele vai auxiliar na cura de um problema. Vai me ajudar a combater o problema que eu estou com ele...

(P) - Como é para você tomar remédio o resto da vida?

(R) - E como eu digo: significa um compromisso a mais que a gente passa a conviver com ele porque sabe que ela vai fazer parte integrante para você poder viver bem, digamos assim.

(P) - E se você deixar de tomar o remédio?

(R) - Taí uma coisa que eu nunca pensei, sabe. A partir do instante que o médico determina que você deve tomar..."

Verifica-se que em toda a fala do depoente não há menção à palavra, e, consequentemente, à ideia, de doença: ele (o remédio) vai me ajudar em termos de saúde; ele vai auxiliar na cura de um problema; vai me ajudar a combater um problema que eu estou com ele. O paciente chega a mencionar cura de um problema, ou seja, a sua vontade de eliminar de si a doença parece tão forte que até a cura, que no uso corrente da lingua portuguesa, é sempre cura de uma doença, de um mal, transforma-se em cura de um problema. 
O medicamento, neste contexto, representa, simboliza e permite o que poderlamos chamar de saúde social, ou saúde formal, porque permite que o individuo seja considerado saudável pelo exterior, pelo social. Das o sentido do compromisso.

$$
\begin{aligned}
& \text { "(P) - O que significa o remédio em sua vida? } \\
& (R) \text { - ...um compromisso a mais, sb..." } \\
& \text { O compromisso a mais parece, neste contexto, ter o }
\end{aligned}
$$

significado de obrigação social a mais, ou seja, uma conduta que o social nos impõe.

$$
\text { O remédio é, finalmente, algo com o qual é preciso }
$$
conviver para você viver bem, digamos assim.

Quanto ao digamos assim, podemos interpretá-lo como qualificando e relativizando o que vem imediatamente antes, ou seja, o poder viver bem (que, por sua vez, está no contexto imediato do discurso do compromisso - formal - a mais).

Assim, o poder viver bem pode ser interpretado como: poder viver de acordo com aquilo que a sociedade exige.

Esta modalidade de consumo de medicamento pode ser confrontada com outras que outros depoentes manifestaram.

"Eu sinto um pouco de canseira, sinto um pouco de falta de ar, essa dor aqui (apontou a nuca) é da pressão. E quando eu sinto que está meio querendo doer, ou está meio preso, eu sei, já tomo o remédio." 
Nesta modalidade de consumo, o medicamento representa, simboliza, a saúde na medida em que incorpora, na sua química de medicamento, no seu significante, a anti-falta de ar, a anti-canseira.

$\mathrm{Na}$ modalidade de consumo que o depoente em tela apresenta, a situação $\varepsilon$ radicalmente diversa: a ideia ou conceito de saúde corresponde outro tipo de significante: um produto químico capaz de produzir não uma sensação física mas um resultado numérico, que permite que este indivíduo seja considerado (pela medicina, pelo "outro") como saudável.

Como o indivíduo que é hipertenso e não sente nada de mau pode dar sentido ao consumo de algo como o medicamento, cujo sentido hegemōnico, na sociedade e na cultura, é justamente o de combater um estado orgānico ressentido - pelo próprio indivíduo - como mau?

Ele pode, dar sentido a este consumo, como faz o depoente: transformando, no plano das ideias, seu estado orgânico considerado bom por ele num estado orgânico considerado mau pelo "outro". Operada a transformaçāo mental, o consumo regular de medicamento passa a ter lógica ou propósito para o indivíduo: torná-lo um ser social aceitável.

O medicamento passa entāo a ter o mesmo valor simbólico da roupa escura, por exemplo: da mesma forma que o compromisso de vestir-se com tecido escuro torna o indivíduo aceitável, considerando o contexto de uma cerimōnia fúnebre, o compromisso de tomar regularmente um medicamento antihipertensivo, torna este individuo aceitável, considerando o contexto do desempenho de uma função pública (em uma Prefeitura, no caso). 
A partir dar, ou seja, a partir do entendimento do consumo do medicamento como exigencia ou compromisso social, é perfeitamente coerente a resposta do entrevistado d questão :

"(P) - E se você deixar de tomar o remédio?

(R) - Tai uma coisa que eu nunca pensei, sabe. A partir do instante que o médico determina que você deve tomar..."

... a palavra deste médico é lei, assim como é uma lei ou compromisso social vestir roupa escura em cerimônias fúnebres, na nossa cultura. 
III.11 - O medicamento e o consumo de uma alteridade negativa 
Haveria que pensar que o fato do significante do medicamento ser um fato químico $€$, obviamente, algo năo aparente, "a olho nu" e, portanto sujeito a variados graus de conhecimento/desconhecimento.

Isto traz uma série de consequências.

Imaginemos aquele espectro de invidíduos (grande parte dos consumidores de medicamentos) que vai desde o desconhecedor total da natureza do medicamento até aquele que apenas sabe que o medicamento é um produto químico sem saber o que isto quer dizer.

Depoimento L):

(P) - "Por que o remédio consegue baixar a pressāo da sra?"

(R) - Olha, aí eu não tenho ideia porque eu não conheço a fórmula dos remédios. Mas eu sei que é pelas coisas que tem, pelas fórmulas lá, não sei. Ele é composto de alguma coisa que faz baixar a pressāo".

Depoimento h) :

(P) - "Como é que o remédio consegue abaixar sua pressão!

(R) - "Aí bom, eu acho que é o efeito que o remédio faz. Acho que é o efeito que remédio faz".

Para este tipo de indivíduo, o medicamento, grosso modo, é concebido como alguma coisa que, engolida, provoca o não-sintoma, a não-doença, assim como ligar a televisão "provoca" a vinda da imagem e do som do mundo. 
O que $\boldsymbol{\epsilon}$ entåo, para este tipo de individuo, este objeto que, engolido, provoca este efeito?

Este objeto, segundo cremos, é o saber cientifico materializado, uma ciência-coisa ou saber científico-coisa. Para estes indivíduos, é o conhecimento científico tornando coisa, sobre a saúde/doença (intermediado ou não pelo discurso médico) que é engolido quando consomem um medicamento.

O que significa "engolir conhecimento"? Ou, colocando a pergunta de outro modo: se o corpo, como todos sabem e sentem, faz parte da Natureza, e se, geralmente, o que eu engulo ou incorporo pela boca (alimento, leite materno, água, chás de ervas, até tabaco), é também Natureza, o que acontece com o medicamento (alopático)?

Ele passa a ser visto, em relação à Natureza, como Artifício. Assim, o que este induivíduo engole é este Artificio.

Quando um indivíduo bebe um chá de maracujá, para ter sono, está bebendo a si mesmo ou mais precisamente, a algo que é fisicamente semelhante a si mesmo na medida em que o maracujá aparece como um elemento da natureza (como o próprio indivíduo), como um suco da "mãe natureza", que estabelece uma linha de continuidade natural com o leite materno, suco da mãe propriamente dita, que é o grande "remédio primordial".

Traduzindo em termos semióticos diríamos que o Indivíduo e o Chá de Maracujá, enquanto símbolos, são constituidos pela mesma materia significante: o elemento natural. 
O sono, neste caso (da mesma forma que o alimento), nåo aparece como um produto criado pelo homem (que pode, portanto, ser bom ou mal) mas como algo necessariamente bom pois Já existente, prevlamente, na natureza, como obra da propria natureza ou do Criador, que o homem não fez mais do que des-cobrir (tirar a coberta).

Já o sono do comprimido, que porta um significante artificial, que aparece como fabricação do homem, como manifestação da atividade do homem enquanto criador de estados de vida, implica que o homem nāo está consumindo a si mesmo como Natureza mas como Cultura, ou, mais precisamente, Ciência.

Assim, ao engolir um medicamento (diferentemente do que acontece com a comida) o indivíduo está engolindo uma "Alteridade" ou seja, incorporando, pela boca, ao organismo o que não é ele.

Isto implica que, ao mesmo tempo que está engolindo uma "alteridade", está engolindo, necessariamente, uma crença ou uma base de confiança empírica no Outro: na Ciência, no cientista, na medicina, no médico.

(P) - "Por que o remédio consegue baixar a sua pressāo?" .

Depoimento g):

(R) - "Bom,isso aí.. quando eu volto no Dr. ... ele me fala que baixou minha pressāo. O médico é que diz e bota lá no relatório". 


\section{Depoimento h):}

(R) - "Porque no café da manhā, o Dr. ... me mandou, eu tomo, então eu tomo e me sinto, né, bem".

Com efeito, a saúde como śmbolo depende de uma crença e de uma base empírica: ela está no comprimido, já que "o médico disse" e/ou "já que eu sinto".

Mas qual a "qualidade" ou força (simbólica) desta crença e desta base empfrica de confiança?

O medicamento parece ser, nesse sentido, um símbolo frágil porque a crença e a base empírica que os sustentam enquanto símbolos também são frágeis, afetando com isso, a relação simbolizante/simbolizado, garantia do vigor do símbolo.

O medicamento parece ser, atualmente, um componente ou área da cultura - aquela que tem como objeto a saúde e a doença - onde ainda não se realizou ou onde há dificuldades para que ocorra a passagem (no nível do simbólico) de uma ordem do natural a uma ordem do artificial.

$\mathrm{O}$ avião funciona, o homem vai à lua, a televisão transmite as Olimpíadas desde o outro lado do mundo, então o medicamento, como produto da tecnologia moderna e enquanto símbolo, também deveria gozar do mesmo crédito. Mas isto não ocorre com a mesma intensidade.

Aqui, a crença ingênua na ciência e nas suas promessas, se defronta com a realidade amedrontadora dos fatos. A ciência, no caso do 
medicamento, mostra claramente as suas insuficiências, manifestadas na persistencia de doenças ou "mal estares" que o medicamento ainda nåo conseguiu controlar ou curar e, sobretudo, nos EFEITOS COLATERAIS, que indicam uma grave fratura interna no mito "medicamento", uma importante contradição interna do símbolo já que o remédio cura (mais "certeiramente", mais "a fundo", mais rapidamente, mais "cientificiamente" que o "chá", que a "erva", etc.) mas vicia; cura mas provoca. dependência, cura a doença mas mata o doente, conserta uma área e afeta outra.

$$
\text { O consumo do medicamento "não natural", parece então }
$$
implicar o consumo de uma "ALTERIDADE" COM SINAL NEGATIVO já que o Homem parece ainda não ter se reconhecido totalmente como criador de vida, o que faz com que, a nível do simbólico, o sono (para citar apenas um estado) enquanto significante, enquanto comprimido, esteja associado ainda com muito temor ao seu significado, se compararmos como o sono veiculado através de um significante como "suco de maracujá", onde a relação significante/significado tem um fundamento aparentemente mais seguro (psicologicamente) na relação motivada (no sentido semítico do termo (76) que une homem e natureza como coisas feitas de uma mesma . matéria prima. 
III.12 - Saúde natural x saúde artificial: uma oposição simbolica 
A hegemonia da mercadoria se exerce sobre o conjunto sociedade e da cultura, inclusive sobre aquilo que aparece exteriormente como reaçăo, como uma "alternativa d̀ cultura dominante".

Tal é o caso das terapias "alternativas" que, na sociedade da mercadoria, rapidamente perdem o seu potencial contestador, dando nascimento a um novo filão comercial a ser explorado. As terapias alternativas passam rapidamente da condição de alternativa à mercadoria para a condição de mercadoria atremativa.

Neste contexto, é criado todo um universo ou campo da "saúde alternativa", composto de uma enorme gama de "produtos alternativos", que aparecem como tal por contraste como o campo da saúde "artificial" com seus correspondentes produtos químicos".

depoimento d):

"E realmente, se há condições de uma forma mais natural, sem ingerir produtos químicos..."

Estes produtos de "saúde alternativa" são uma variante de mercadorias simbólicas de saúde. Estas mercadorias simbolizam "saúde natural", por oposição a "saúde artificial".

Tal é o caso dos medicamentos homeopáticos * * Na análise destes como símbolo de saúde natural, podemos observar, dentro da oposição

- E preciso, reiterar que a análise que fazemos diz respeito à semiose social de que fala VERON (79). Não se trata portanto da polêmica tecnica entre homeopatia e alopatia. 
semântica: saúde natural x saúde artificial algumas oposiçōes semânticas subsidiárias. Como por exemplo, a oposiçăo entre efeito especifico e efeito geral.

"Mas eu nunca tomei remédio específico para pressão alta. S6 medicamentos homeopáticos, que não é assim específico para pressão alta: então esse tratamento de fundo vai atuar no corpo todo, nāo em sintoma mas em todos os sintomas gerais que a pessoa possa oferecer. $E$ as vezes que eu tive alteraçōes de pressāo, foi com a homeopatia que eu fiquei joia."

A "saúde natural" através de um dos seus símbolos, o . medicamento homeopático, é global, por oposição à saúde artificial, representada pelo medicamento alopático, que é específica, já que GLOBAL está ligado ao organismo como ele parece ser, ou seja, como um sistema interligado, enquanto ESPECIFICO está associado a uma partição articial do organismo.

A saúde natural através do medicamento homeopático, implica, de outra parte, numa terapia individualizada, por oposição à saúde artificial que supōe um tratamento genérico:

"A homeopatia é um tratamento assim que conforme a pessoa, a sua individualidade, o que ela gosta de comer, o que ela gosta de fazer, de. acordo com os sentimentos: a gente está depressiva, ou se a gente está com muita raiva, o pessoal mais colérico, então aqueles traços de personalidade que definem o remédio que vai ser típico daquela pessoa, que é que eles chamam de remédio de fundo."

Observermos que, do ponto de vista que nos interessa, na homeopatia a saúde continua sendo vista como uma mercadoria simbólica. Configura a homeopatia, como dissemos, não uma alternativa à mercadoria mas apenas uma mercadoria alternativa. 
Com efeito, a saúde continua concentrada numa coisa, num medicamento, ela continua sendo objeto de um processo de reduçáo almb6lica. Além disso, o medicamento homeopático tambem năo se parece, a nivel do significante, com a natureza já que continua sendo um comprimido, como o remédio alopático.

No entanto, como mercadoria alternativa, o medicamento homeopático se apresenta, no mercado de bens de saúde e na dimensão simbolica deste mercado como algo diferente. $\mathrm{E}$ a diferença que ele alardea $e ́$ que o seu produto oferece mais saúde (assim como OMO oferece mais brancura, o último filme de James Bond, mais aventura, o último disco de Roberto Carlos, mais romance, etc. )$*$

E o que é esta saúde a mais que a homeopatia oferece, de acordo com o depoimento acima (que parece traduzir bem o discurso homeopático)? E a ideia de que, na homeopatia, a saúde está mas próxima da ordem natural das coisas, que consiste no fato do paciente ser, para a homeopatia, um organismo e não um agregado de orgãos e no fato deste organismo ser uma entidade totalmente particular: com vontades, gostos, temperamento e personalidade próprios.

O importante a frizar, parce-nos, é que para compreender este depoimento, é preciso situá-lo no interior do campo do simbǿlico, ou mais precisamente na dimensão simbolica do mercado de bens de consumo de saúde, como expressando uma competição mercadológica que tem lugar neste campo.

Fora deste quadro de referência, permanece-se preso à

\footnotetext{
" Este "mais" é qualitativo e não quantitativo
} 
Fora deste quadro de referência, permanece-se preso a crença ingênua e mística de que é possivel resolver as complexíssimas questóes da saúde e da doença no mundo contemporâneo através de uma pflula, qualquer que . seja ela. 
III.13 - O medicamento e a relação de comunicação 
O medicamento pode ser visto no contexto de uma relação de comunicaçăo que envolve um emissor, que é o proprio organismo...

Depoimento a):

"E não precisam nem falar, vai tomar o remédio. É meu próprio organismo, quando está precisando, requisita."

Depoimento b):

"Tem temporadas que ela (a hipertensão) ataca, tem temporadas que acalma."

...um receptor, que é o Ego ou a consciência correspondente a este organismo...

"É meu próprio organismo, quando está precisando, requisita (O organismo que requisita, requisita para alguém, que é o seu próprio ${ }^{\text {. }}$ Ego)."

..um segundo receptor, que $\varepsilon$ a autoridade de saúde (médico, enfermeira, farmacêutico) dotada de extensōes tecnologicas de seu aparelho auditivo e visual (por exemplo, o esfingtomanômetro)...

depoimento g):

"(P) - E como é que o sr. acha que o remédio baixou sua pressão? 
$(R)$ - Bom, isso al... quando eu volto no médico, o Dr... ele mede, ele me fala que baixou a pressão. O médico é que te diz, e bota lá no relatório, na ficha lá, e ele conversa comigo, me explica se está alta, se está baixa..."

mensagens de Ida (sintomas, sensações, estados press6ricos) e mensagens de volta ou respostas (condutas alimentares, condutas medicamentosas)...

Depoimento i):

"( $R)$ - Quando eu estou assim muito agitada, muito nervosa, comę̧a a me doer muito a nuca, assim eu já percebo que o negócio está um pouquinho alto, aí naquele dia eu não janto, se almoşo como um pouquinho, quer dizer, quanto menos comida eu como menos sal entra, né?

$$
\begin{aligned}
& \text { (P) - E daí? } \\
& (R) \text { - É isso aí. } \\
& (P) \text { - Daí volta a tomar o remédio? } \\
& (R) \text { - Não, o Clorana eu não dispenso. } \\
& \text { (P) - E o outro? } \\
& \text { (R) - O outro é um horário meio ruim... Mas se eu fico dois, }
\end{aligned}
$$
tres dias sem o Clorana, fico com as mãos inchadas, me incha logo os olhos, assim..."

\section{Depoimento a):}

"Então eu fico com aquele enjoo, aquele enjoo, em vez de tomar o remédio para o estômago, eu tomo o da pressão. E é exatamente o que sara. Ela se manifesta como enjôo." 
Uma doença crônica como a hipertensâo implica em dois tipos búsicos de relaçáo de comunicaçáo envolvendo o medicamento. Ou seja, quamoto o paciente hipertenso é obrigado a dar uma resposta medicamentosa diária ao seu organismo porque este organismo padece de pressåo alta, duas situaçð̄es comenicacionais são possíveis:

A) Numa, organismo as vezes emite as vezes não emite mensagens de doença, para o receptor/ paciente (porque está emitindo mensagens - a pressāo alta - diretamente para o sistema de escuta do receptor/médico).

Neste último caso, o silêncio do emissor/organismo, do ponto de vista da escuta do Ego, pode não ser interpretado, por este Ego, como representando saúde, porque ele sabe que o seu sistema leigo de escuta da doença, às vezes não capaz de detectar a presença desta.

\section{Depoimento c):}

"(P) - E se não tomar (o medicamento) de vez em quando, o que acontece?

(R) - Ah, eu vou medir... Às vezes está bem, estou disposta, vou lá medīi a pressão está 19,21. Parece que estou tão bem, né? Chego lá e ela está 21... e eu como 21 de pressão eu me sinto parece joia, parece que estou no céu.(...)"E às vezes também tem hora que eu estou com a pressão alta e não sinto nada. Não tenho nada Não tenho dor de cabeça, não tenho nada. E está alta."

Isto implica em admitir a presença - dentro de uma relaçāo habitual de comunicação envolvendo a saúde-doença, em que o emissor orgarismo emite mensagens de doença detectadas pelo sistema de escuta do Ego - de uma outra relação de comunicação envolvendo, diretamente, emissores orgânicos e 
receptores do segundo tipo, ou seja a instancia medica com seu sistema de escuta tecnica e tecnológica dos organismos.

$$
\text { depoimento h): }
$$

"(P) - A sra toma remédio porque não está se sentindo

bem?

(R) - Não eu estou me sentindo bem. Então porque eu tomo, né? Eu preciso falar com o Dr... Dr.: eu posso tirar o Higroton? Agora eu poderia experimentar, né? Tirar para ver o que acontece, né?"

$\mathrm{Na}$ hipertensão pode haver então, às vezes, o poderíamos chamar de "pane de comunicação" entre o organismo e o Ego.

Vemos, por este depoimento, que o indivíduo, colocado diante do fato, dificilmente comprensível, em termos de lógica do consumo de mercadorias e da lógica do consumo da mercadoria medicamento, de um modo geral (lógica essa que supõe um mal estar antecedente, o consumo do medicamento e o bem estar consequente) coloca em questão a sua conduta chegando mesmo a imaginar um teste empírico (..."eu poderia experimentar... para ver o que acontece"...).

B) Um outro tipo de relaçāo de comunicaçāo o paciente hipertenso não sente sintomas e toma diariamente o medicamento. Nesse caso ele é necessariamente alguém que é doente para o "outro" : para o médico, para a ciência, para a medicina, para a sociedade medicalizada.

Com efeito, na ausência de uma comprovação empirica traduzível em sensações suas, este comportamento (consumir medicamentos diariamente) só pode estar associado à crença e à obediência à palavra: da ciência, da . 
medicina, do médico, enfim, da Ordem Médica.

Como imaginar, com efeito, uma situaçåo na qual os atores do processo de comunicaçăo que envolve a saúde, a doença, a vida, a morte, o dia a dia, do indiv̛́duo, são o emissor/organismo e a mensagem/medicamento e o receptor/médico, sendo que o maior interessado nisso, o próprio indivíduo, é um mero implementador de um processo que lhe é estranho?

Parece claro que isto implica numa crença total na verdade médica: viver combatendo diariamente com medicamentos e restrições alimentares, um inimigo que não se manifesta orgânicamente, ou seja sem nenhum testemunho empírico (legível pelo leigo) que justifique este combate, supōe, correspondentemente, a crença absoluta na palavra do médico.

Esta obediência pode se concretizar pela adoção da medicina como crença ,do médico com o sacerdote e do medicamento como símbolo de saúde, no contexto de uma religião secularizada, de tal modo que o paciente aliene completamente a sua vontade e o controle de seu organismo:

depoimento g):

"(P) - O sr. sente alguma coisa?

(R) - Normalmente não sinto nada. Porque o Dr... mesmo, ele, quando eu vou lá, ele fica dizendo isso aí, que eu não sinto nada (...).

(P) - Como é que o sr. toma remédio e não sente nada?

(R) - Eu sim, porque o Dr... ele mede a pressão, ele me diz que a pressão está alta, ele conta para mim que a pressão está alta, entāo eu sigo... continuo tomando os remédios e quando ele marca o dia de voltar lá eu volto, para ele me examinar." 
Como pode-se perceber por este depoimento o paciente aliena o seu proprio sentir em favor do médico: "ele fica dizendo", isso al, "que eu não sinto nadan

$\mathrm{Na}$ sequência do depoimento, fica patente a total submissão e passividade do paciente diante da Ordem Médica: ele mede... ele me diz... ele conta para mim... entäo eu sigo... ele marca.. eu volto... ele me examina.

O medicamento, no caso do paciente sem sintomas, que o consome diariamente, simboliza então a presença diária, no Ego do paciente, do Poder Médico, ou se se preferir uma formulação mais radical, o domínio do Ego do paciente por este Poder Médico.

Quando o paciente hipertenso sente sintomas, que ele atribui à sua hipertensāo, a sua relaçāo de comunicação com o Poder Médico pode se alterar (o que não quer dizer, evidentemente, que sempre se altere) pela presença destes sintomas entre o paciente e o médico.

Há, néste caso, uma relação a três: o paciente, seu organismo como emissor de sintomas (mensagens de saúde/doença) e o Poder Médico.

Parece claro que a existência deste tertius - o organismo emissor - permite relativizar o poder médico e a crença dele decorrente. 
depoimento b):

"(P) - Pode acontecer alguma coisa com a sra. se de vez em quando deixar de tomar o remédio?

(R) - Não. Pode ser que aconteça, não sei. Mas eu tenho esse pensamento. Porque eu não deixou muito tempo de tomar. É dois, tres dias, só. Depois eu tomo, dia sim, dia nāo, ou todo dia, conforme eu sinta, né? Depois eu paro dois, tres dias, mas não é sempre. As vezes eu passo um mês tomando bem, outras vezes paro um pouco. Quer dizer, eu não sou fanática de tomar todo dia o remédio, se eu acho que eu nāo preciso. Agora, quando eu preciso, eu tomo."

A presença ou ausência do sintoma permite que o depoente se auto atribua a capacidade regular a medicação em função da emissāo ou nāo de mensagens, que ele atribui à doença hipertensiva, pelo organismo.

Em síntese, a ausência de mensagens de doença emitidas pelo organismo para o paciente (onde portanto só há um receptor em cena: o médico) permite a presença, no campo de significaçōes, da crença, do poder absoluto, da obediência, enfim, do universo binário. Já a presença do organismo como emissor de mensagens de saúde/doença para o paciente (e, naturalmente, também para o médico), configurando a presença de dois receptores, introduz mais um elemento no campo de significações, consubstanciando assim um universo ternário, e portanto não absoluto, dando ensejo a manifestações - pertinentes ou não pertinentes, não vem ao caso, no momento - de livre arbítrio do paciente,como o comportamento de automedicar-se, por exemplo.

Neste contexto de relação de comunicação, o medicamento como símbolo de saúde é um fator que possibilita a emissão de 
mensagens de saúde emitidas pelo Ego do paciente como resposta a mensagens de doença (sintomas) emitidas pelo seu organismo.

O que torna o problema complicado, num quadro de hipertensão, é que o organismo não se comporta como um emissor de mensagens (do tipo: "estou doente", "estou sadio"; "estou hipertenso", "estou normotenso") que seja sempre um sujeito "leal" ou transparente para o Ego que lhe corresponde, tornando problemático para este Ego, o exercício da "liberdade de medicar-se" ou seja de produzir, através do medicamento, a sua própria saúde,no quadro de uma sociedade de consumo regida pela lógica do EN (Estado de Necessidade) - P (Produto) - ES (Estado de Satisfação).

O que este exemplo da relação de comunicação na hipertensāo nos revela, no que toca ao problema que nos ocupa especificamente, qual seja, o medicamento no contexto da relação de comunicação envolvendo o tema da saúde/doença?

Que o papel e o estatuto do medicamento, hoje, nas sociedades de consumo como a nossa é problemático na medida em que ele é um objeto dúplice.
a) uma mercadoria simbólica
b) um agente quimioterápico.

Enquanto mercadoria simbólica, o medicamento existe no contexto de uma sociedade de consumo - como mensagem-resposta de saúde no quadro de uma relaçao de comunicaçāo entre o emissor-organismo do indivíduo como fonte de mensagem-necessidade e o seu Ego como receptor. 
Ocorre que o medicamento é também um agente quimioterápico e, nesta qualidade, existe no contexto de uma relaçăo de comunicaçăo entre o emissor-organismo do individuo nåo como fonte de mensagem-necessidade mas como fonte de mensagens tecnico-especializadas, indicativas de um estado $x$ situado em algum lugar do contínuo saúde-doença. Estas mensagens" " são dirigidas para o Ego do médico, que as decodifica e interpreta.

Ora, na prática, no dia a dia (como a análise do papel do medicamento na hipertensão sugere) estes dois processos "comunicacionais" são um s6 processo. Dito de outro modo, o que o problema do medicamento na hipertensão indica é que este medicamento é, não apenas na hipertensão mas de uma maneira geral, ao mesmo tempo, mercadoria simbblica e agente quimioterápico e que o processo comunicacional no qual está inserido é extremamente complexo.

Nesta linha de análise, como indicamos no inf́cio deste

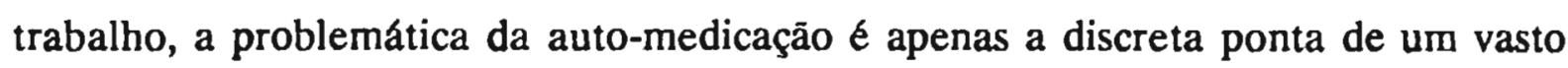
"iceberg" submerso.

\footnotetext{
- Passando ou não pelo Ego do indivíduo. Com efeito, do ponto de vista do médico e da medicina, este não é um receptor mas uma extensão do organismo, a ser lido e interpretado pelo médico: a fala do indivíduo, na anamnese, tem o mesmo status "comunicacional" que, por exemplo, a sua pulsação, a sua pressão arterial, etc.
} 


\section{III.14 - O hipertenso como consumidor}

exemplar de medicamento 
Após a tomada de contato com a análise destes depoimentos de pacientes hipertensos é necessário reiterar algo que já foi dito sobre o "status do paciente hipertenso no trabalho" (2.1.1.), onde se afirma que estes depoimentos representam uma contribuiçăo do hipertenso para o sentido do medicamento".

Assim, reiteramos que, aqui, a vivência dos pacientes hipertensos fornecem dados, exemplos de caracteristicas que acreditamos serem gerais, acerca do sentido que envolve o medicamento, do ponto de vista dos individuos.

Evidentemente, se a pretensão fosse estudar o paciente hipertenso (ou o diabético, o aidetico, o consumidor eventual de analgésicos, o indivíduo de "fé" macrobiótica, "ideologicamente" avessso a qualquer medicamento,etc.), se a pretensão fosse estudá-lo na sua especificidade, poderia ser considerado como um atribuidor de sentido particular ao medicamento. Mas, certamente, o hipertenso não foi visto sob esta 6tica, neste trabalho.

Apenas para ilustrar esta colocaçāo, diríamos, em relação aos sub-temas derivados da ańlise dos depoimentos, que, por exemplo:

- a questão geral da eficiência/eficácia simbólica - que foi amplamente discutida na análise que se fez da frase-slogan:"tomou Doril a dor sumiu" e nas análises do conceito de rapidez - presente nas propagandas de medicamentos traduz-se, nos depoimentos dos hipertensos, entre outras, na temática associada à oposição :"cura x controle";

- a questão geral do remédio como "mal necessário" (inserida no sub tema:"o medicamento, ambiguidade e moral") brota, no relato do hipertenso, em função do seu convívio permanente com o medicamento (ou seja, por 
razסes que ,metaforicamente, poderfamos chamar de "quantitativas") pode perfeitamente estar também presente naquele individuo que, por força de algum acontecimento particularmente perturbador, recorre a um calmante ou naquela măe que $e$ compelida a dar um antibiótico para o filho pequeno acometido de uma infecçáo (ou seja, por razōes que, também metaforicamente, poderlamos chamar de "qualitativas");

- não apenas o hipertenso pode sentir-se um "deficiente químico" e atribuir sentido ao medicamento considerando esta condição.Esta sensação e o sentido que lhe corresponde podem também, perfeitamente, estar presentes naqueles consumidores "assíduos" de laxante, a que se refere HAFEN (38),que se auto-medicam nesta direção porque crêem constituir anormalidade não evacuar todos os dias.

Em síntese poderíamos dizer -e isto parece um truismoque o particular, o individual, pode ser entendido seja como sentido único, específico, idiossincrático, seja como exemplo ou ilustração de um sentido geral.

Especificamente, no caso do paciente hipertenso, diríamos que ele pode ser visto, na qualidade de atribuidor de sentido ao medicamento, seja como um consumidor particular de medicamento, seja como um consumidor exemplar de medicamento. Obviamente, a opção adotada neste trabalho foi a segunda. 
IV - CONCLUSÕES E RECOMENDAÇõES 
IV.1 - Eixos temáticos 
Como se observa facilmente, este trabalho deu lugar, com base na perspectiva térica de análise, ao levantamento de uma temática variada que cerca o medicamento hoje, em nossa sociedade e cultura.

E necessário, pois, tentar organizar a referida temática, sob a forma de eixos temáticos agregadores, que permitam a elaboração de propostas de tarefas, no que toca à elaboração de trabalhos científicos que, por sua vez, darão lugar a propostas de atividades de natureza educativa e assistencial a serem desenvolvidas na rede pública de saúde.

Nesse sentido, do trabalho como um todo ressaltam os seguintes seis eixos temáticos:

1) $O$ medicamento e a oposição: artificial $x$ natural.

2) O medicamento no contexto de uma relação de comunicaçāo.

3) O medicamento como símbolo ambíguo de saúde e doença.

4) O medicamento e a moral: obediência e transgressão; autonomia e heteronomia.

5) O medicamento e o desejo: eficiência e eficácia simbólica.

6) O medicamento e a relação de consumo.

Com estes seis eixos busca-se uma das sinteses possíveis* da temática associada ao medicamento como objeto da Educaçāo em Saúde Pública.

\footnotetext{
* Evidentemente, sendo a realidade polissêmica e permitindo, portanto, várias leituras legítimas, outros eixos ou conjunto de eixos são possíveis.
} 
IV.2 - Hipoteses 


\section{A) Preámbulo.}

As hipoteses relativas aos seis eixos temáticos constituem, portanto, parte das tarefas acima levantadas.

Cada uma destas hipóteses são compostas de duas partes. $\mathrm{Na}$ primeira parte procura-se descrever, genericamente, o conteúdo do eixo temático (utilizando,nesta descrição,frequentemente, "citações" de trechos do capítulo III, para indicar que as hipóteses são um trabalho sobre esta "matéria prima") .Tal descriçāo tem o fito de tornar este conteúdo mais explícito. $\mathrm{Na}$ segunda parte procura-se expressar o eixo em forma de hipotese.

As hipóteses tem algumas características que precisam ser destacadas:

a) Elas se referem aos usuários. A opção pelo usuário nāo implica, obviamente, que apenas estes possam ser objeto de hipóteses. As duas outras faces do tripé constituido pelos sujeitos atribuidores de sentido ao medicamento, ou seja o ponto de vista do social e o ponto de vista do médico podem também, evidentemente, ser objeto de hipoteses.

Parece-nos contudo que, para a Educação em Saúde Pública, o usuário é o sujeito prioritário por ser ele o elemento mais influenciável do tripé, ou que apresenta grau maior de mutabilidade.

b) Elas consideram o usuário de medicamentos como apresentando uma tripla face: 


\section{b.1 - paciente \\ b.2 - individuo \\ b.3 - consumidor}

O usuário de medicamentos é paciente enquanto pertence a categoria dos indivíduos doentes (crônicos ou agudos); o usuário é indivíduo enquanto membro de uma cultura, de uma sociedade e o usuário é consumidor, enquanto individuo inserido numa relação de consumo de mercadorias.

Evidentemente, todo usuário de medicamentos possui estas tres facetas, em maior ou menor grau. Assim, se algumas hipóteses se referem ao usuário na sua tripla face, outras a ele se referem enquanto portador, em maior ou menor grau, de uma ou outra destas facetas.

c) Mesmo dizendo respeito, fundamentalmente, ao usuário, as hipóteses pressupõe que este,na qualidade de portador do ponto de vista do indivíduo vivendo numa dada sociedade,está, sempre, envolvido com o ponto de vista do social e com o ponto de vista dos médicos, em relaçōes de submissão, rebeldia, hegemonia,etc.

B) Hipóteses.

1) O medicamento e a oposição artificial versus natural.

No campo da saúde/doença, em nossa cultura, o Homem parece ainda estar vivendo um conflito entre a sua condição de criatura da vida, da natureza e criador de vida, de natureza. 
Como consequência, a relaçăo significante significado, no m=un matureza, como coisas feitas de uma mesma materia prima, e na

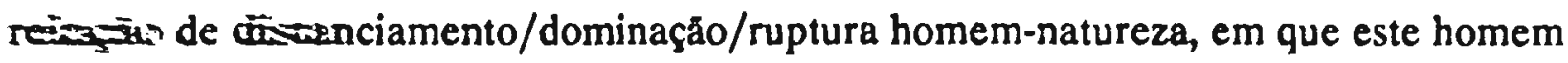
spresc comi Senhor do Corpo, entendido como máquina.

Esta problemática tem reflexos no mercado de bens de corsmo de sañ de (é a oposição "produto natural x produto químico), expressando a fac simbolice de uma competição mercadológica ou - dentro da visão do ideológico que aciotamios em que infra-estrutura e super estrutura não são compartimentos eswerçues - a mercadológica de uma competição no plano do simbólico.

Hipótese: O medicamento "químico" é vivido pelos

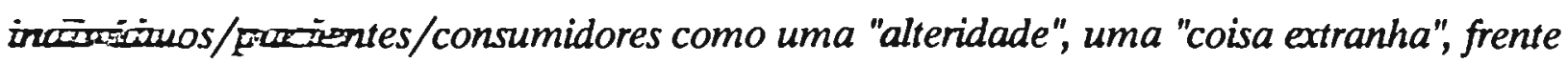
à Drespisem o reflexo ou reinterpretação, nos individuos, da oposição: natural $x$

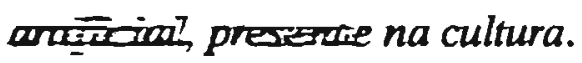

2) O medicamento e a relação de comunicação.

Num contexto de relação de comunicação, usando o me-inamence como símbolo que lhe permite "falar saúde", na linguagem da saúde corrse açăo social (o que é coisa muito distinta de falar,usando palavras como simioios, sotare a saúde como tema) o paciente é capaz de emitir mensagens de saúñ respose a mensagens de doença (sintomas) emitidas pelo seu organismo.

\footnotetext{
- Enr cone uma cralidade material, funcionando como significante de saúde, pode "imitar" a natureza (por emplo, esas de árvore, nos "medicamentos naturais") ou "imitar" a civilização tecnologica (por mañ monte de plático contendo grânulos, nos medicamentos "químicos").
} 
O médico, neste contexto, figura também como um emissor de respostas, só que de natureza diferente porque as "questóes" que lhe são colocadas provém da escuta ou alscuta do "outro" (o organismo do paciente).

Colocar o problema da saúde/doença em termos de relação de comunicação implica, entre outras, na questão crucial, nos dias de hoje: para quem fala o organismo? Para o seu Ego? E/ou para o gigantesco aparelho tecnológico de escuta, de visão (tomógrafos, a parafernália dos exames de laboratório, ultrassonografia, etc.), que se vem desenvolvendo, historicamente, de maneira exponencial? Isto implica a desqualificação progressiva dos indivíduos comuns como intérpretes ou decodificadores das mensagens de saúde /doença emitidas pelo seu organismo?

$\mathrm{Na}$ hipertensão o problema do medicamento, para o indivíduo, considerado na qualidade de consumidor, pode se tornar complicado porque o seu organismo pode não se comportar como um emissor de mensagens (do tipo: "estou doente", "estou sadio"; "estou hipertenso", "estou normotenso") que seja sempre "leal" ou transparente para Ego que lhe corresponde, tornando problemático, para este Ego, o exercício da "liberdade de medicar-se" ou seja, de produzir, através do consumo do medicamento, a sua própria saúde como mensagem.

Hipótese: $O$ medicamento é vivido pelos indivíduos, consumidores, pacientes, como uma mensagem-resposta de saúde a uma mensagem de doença emitida pelo seu organismo, no contexto de uma relação de comunicação em que figuram, também, o médico e os aparatos tecnológicos de asculta do organismo.

3) O medicamento como símbolo ambíguo de saúde e doença (ou como objeto bom e mau). 
A ambiguidade que 0 medicamento representa para 0 individuo advém do fato de que ele indica, ou significa, ao mesmo tempo, o preenchimento de algo que falta a este indivsduo (ou seja, a saúde perdida e recuperada no medicamento) e o fato mesmo de que algo lhe falta (a doença).

Esta ambiguidade do medicamento está também ligada ao fato dele ser vivido pelo paciente, ao mesmo tempo como cura (ou alívio) e intoxicação. Curioso verificar que do ponto de vista do social e do ponto de vista médico esta intoxicaçāo (ou o lado mau do medicamento: o efeito colateral, a contra indicaçāo) não aparece como intrínseco ao medicamento mas como uma potencialidade negativa, controlável pelo saber e pela prática médica, como algo que "só é mau fora das mãos do médico": este lado mau do medicamento aparece então como extrínseco a ele, como uma espécie de punição da qual o paciente que se auto medica, reduzido à condição de "criança arteira", pode ser vítima.

Hipótese: $O$ medicamento é vivenciado pelos seus consumidores como significando, ao mesmo tempo, o acesso à saúde nele concentrada e como testemunho de um estado de doença, ou como manifestação concreta do fato de que a saúde não está onde "deveria" estar, ou seja, no organismo, mas fora dele, no medicamento. Em uma palavra, o medicamento é a saúde fora de lugar.

4) O medicamento e a moral: obediência e transgressão; autonomia e heteronomia.

O medicamento aparece, no mundo do paciente, como um símbolo frágil porque pertencente à ordem dos seres humanos, ordem esta contestável, porque seus membros perderam a característica anterior de representar, no campo da saúde, uma vontade superior, permitindo assim, pelo menos 
virtualmente, a divergência já que o terreno do embate situa-se agora, totalmente na terra.

A hipertensăo oferece um exemplo claro do problema moral da obediência $\mathrm{x}$ transgressão e da autonomia $\mathrm{x}$ heteronomia. Aqui o medicamento pode assumir sentido distinto para o médico e para o paciente. A hipertensão, para o médico, pode ser vista sobretudo como um valor numérico (que é um símbolo, ou representante, ou expressão, na cultura médica, da hipertensão). Esta se inscreve, para ele, na perspectiva temporal da consulta e no espaço do organismo alheio como suporte de uma pressão.

Para o paciente, a hipertensão pode estar sendo representada, simbolizada, expressada, sobretudo, por um sintoma, por uma sensação corporal, que se inscreve na temporalidade do seu dia a dia de paciente e no espaço do seu organismo como suporte desta sensação.

Pontos de vista distintos, portanto, que se refletem em percepções e usos distintos do medicamento, sugerindo, para a Educação em Saúde a questão de saber se na hipertensão - e alhures - a problemática do uso do medicamento pode ser colocada simplesmente em termos de cumprimento ou descumprimento das recomendaçōes médicas.

Hipótese: Para o paciente, a problemática da obediência ou transgressão das ordens médicas, no que se refere ao medicamento, deve ser vista no contexto da autonomia e heteronomia, em que se chocam a perspectiva do paciente e do médico frente à saúde e à doença, buscando o paciente utilizar o medicamento como instrumento desta autonomia, ou seja do controle do seu próprio corpo. 
5) O medicamento e o desejo: eficiência e eficácia simbolica (o medicamento como "objeto bom"*.

"Tomou Doril, a dor sumiu" é a frase/slogan que resume bem a problemática da eficiência (rapidez de resposta: tomou Doril - ato contínuo - a dor sumiu)e da eficácia (a produção da saúde, o "sumiço" da dor) simbólica associada ao consumo do medicamento.

No caso da hipertensão, a eficiência e a eficácia simbólica menor do medicamento que controla em comparação com o que cura decorre de sua incapacidade (e da frustraçāo a ela associada) de eliminar,de uma vez por todas, o Ser doente, já que a sua ação se limita ao Estar doente.

O medicamento pode ser entendido num contexto "desejante" (em termos da Psicologia), em que o Desejo encontra-se com a Possibilidade - através das "magic bullets" de que fala DIXON (27) - de rapidamente, instantaneamente, magicamente (eficiência) realizar a "morte" da dor, do desconforto e o triunfo da vida, do prazer (eficácia).

Hipótese: $O$ medicamento é vivido pelo indivíduo/paciente/consumidor, no contexto do desejo de obtenção da máxima eficiência e eficácia na eliminação da doença (da dor) e na obtenção da saúde (do prazer).

- É claro, pois, que a hipótese 5 exlclui a hipótese 3 e vice versa. 
6) O medicamento e a relaçáo de consumo.

A problemática da hipertensáo serve, desta vez, para ilustrar a questáo do consumo de medicamentos associada à questáo da necessidade.

Com efeito, paciente crônico deve consumir cronicamente o medicamento. É preciso portanto que esta ingestão crônica do medicamento perfaça um sentido para o individuo. Posto que o medicamento é uma mercadoria, este sentido pode se expressar sob a forma de necessidade, que a mercadoria medicamento deve satisfazer.

Alguns pacientes passam entāo a viver a hipertensão como uma necessidade e consequentemente o uso do medicamento para o enfrentamento de uma condiçāo - a pressão alta - transforma-se em uso do medicamento para o enfrentamento de uma situação, ou seja, dos sintomas, ou do que os pacientes creem ser os sintomas, da pressão alta: tonturas, náuseas, enjoos, inchaço, nervosismo..

Hipbtese: $O$ paciente produz o sentido do medicamento influenciado pela sua condição de portador de sintomas ou sensaçoes, que são "semantizados" pelo sistema social inclusivo (e internalizados pelo paciente) como necessidades. Portanto, o consumidor "necessitado" busca "respostas" sob a forma de mercadorias como o medicamento que "resolvem" ou consomem, estas necessidades. 
IV.3 - Conclusão Geral 
IV.3.1 - o Sentido da Saúde e a Educaçáo em Saride.

Enquanto prática de intervençăo sobre individuos e grupos, a Educaçáo em Saúde Pública está, necessariamente, lidando como sentido da saúde.

Ora, este sentido $e$ uma entidade complexa e enquanto tal deve ser tratada, teórica e metodologicamente, pela Educação em Saúde.

Dizer que este sentido $\varepsilon$ uma entidade complexa equivale a dizer, pelo menos, que:

a) ele não se dá a conhecer facilmente, pelos indivíduos:

b) é necessário dar condições (de clima psicologico, de confiança, de transparência, de identificação) para que os indivíduos revelem o seu sentir e seu pensar profundos;

c) este sentir e pensar precisam ser analisados de tal forma que desta análise resultem pontos de vista de categorias de indivíduos (ou pacientes ou consumidores) e não de indivíduos isolados;

d) estes pontos de vista de categorias de indivíduos precisam ser confrontados com os pontos de vista do social e do médico.

Lidar com o Sentido da Saúde implica também, sempre, um engajamento ideológico, mesmo que o educador dele não esteja consciente. 
Assim sendo, sob pena de trair sua vocaça maior, ou seja a luta pela instauraçáo da Saúde como património do Homem (e năo de uma corporacho profissional, de um governo, de um sistema social e ideologico) (60) a Educaçáo em Saúde, na qualidade de meta-intervençăo* , năo pode exposar nenhum dos sentidos que emanam dos pontos de vista (da sociedade, do indivíduo e do médico) sobre a saúde, salvo, evidentemente, se estes pontos de vista coinciderem com os seus.

* Entende-se por "metạ intervenção" o fato de ser a Educação em Saúde a responsável pela dimensão educativa da atividade de saude como um todo, o que, desde logo, implica na recusa em considerá-la como linha auxiliar da intervenção médica, odontológica, de enfermagem, de nutrição, etc. 


\section{IV.3.2 - Sentide global e sentido particular.}

$\mathrm{Na}$ busca do sentido do medicamento atualmente, em nosso país pode-se entende-lo* como uma das expressões mais nítidas de um processo de reificaçāo mercadológica/simbolizaçāo da saúde, que se traduz por uma hipertrofia da sua dimensão orgânica.

Concentradamente, em seu estado mais puro, este processo expressa, no entanto, apenas o ponto de vista do social (representado pelas forças sociais hegemônicas) como instância atribuidora de sentido ao medicamento.

O sentido global do medicamento** é na nossa sociedade e na nossa cultura, portanto, mais do que isto já que envolve outras instâncias atribuidoras de sentido. Este sentido global é composto pelo ponto de vista do social interagindo com o ponto de vista dos indivíduos/pacientes e com o ponto de vista dos médicos (e/ou demais dispensadores oficiais e extra oficiais de assistência à saúde), configurando relações complexas de hegemonia, de alianças, de transgressão, de submissão, de poder, de contra poder e outras. O sentido global do medicamento é, portanto, uma resultante histórica destas relações.Chamemos a este sentido global: sentido global/global. Ele configura o que acreditamos ser uma verdade genérica, que diz respeito a um social genérico (a ideologia dominante) e a atores genéricos (o médico, o paciente).

* O que não quer dizer que o medicamento seja...Como afirma ECO: " $E$ de fato diferente dizer que um objeto é essentialiter (em itálicos no original) alguma coisa ou que deve ser visto sub-ratione (em itálicos no original)desta alguma coisa".(pag.5).

** Sentido global não deve ser confundido com sentido exaustivo; com efeito, não se cogitou, absolutamente, neste trabalho, de buscar qualquer tipo de definição exaustiva do medicamento mas de analisá-lo segundo uma ótica que se acredita pertinente para os propósitos da Educação em Saúde Pública. Nessa medida, o medicamento enquanto objeto das ciências a ele vinculadas (medicina, farmacologia, bioquímica) s6 nos interessou na medida em que a 6tica adotada o requeriu. 
Esta verdade genérica define, digamos assim, um conjunto A, composto pelo enfoque dialético numa dada conjuntura histórico-social, no tratamento do medicamento como objeto tébrico - prático da educação em saúde pública.

O presente trabalho representa uma contribuição na tentativa de definir os contornos deste enfoque.Algo que poderíamos chamar, utilizando a terminologia de ALTHUSSER (2) de "genralidade III preliminar".

Como se trata de um trabalho exploratório, de geração de hip6́teses, é necessário, evidentemente, testar o referido enfoque.

O teste - em populaçōes representativas de indivíduos/pacientes/consumidores - diz respeito tanto ao enfoque quanto à temática levantada.

A testagem deve permitir que este Conjunto A dê lugar através de pesquisas particulares de natureza demonstrativa - a sub-conjuntos a', a"...e que cada sub conjunto deste conjunto maior permita detalhar, tanto quanto possível, cada um dos tres grandes atribuidores de sentido ao medicamento: o social, o médico(e/ou outros profissionais de saúde) e o paciente (ou indivíduo ou consumidor), com ênfase neste último, bem como as suas variadas e variáveis interrelaçōes.

As pesquisas particulares implicam, desta forma, o que poderíamos chamar (comparando com o sentido global/global) de sentido global/particular, ou, "althusserianamente", "generalidade III". Ou seja, elas envolvem este sentido global, considerado necessário e inclusivo, mas submetem-no ao necessário teste empírico. 
As pesquisas particulares deverăo, assim, permitir a retroalimentaçăo do conjunto $A$, fazendo com que ele possa ir se transformando, progressivamente num repositório de princípios gerais sobre o Sentido do Medicamento para a educaçáo em saude como teoria e prática. 
IV.4 - Recomendações 


\section{É claro que de um trabalho exploratorio como o presente} só podem derivar diretamente propostas de investigaçáo e năo de Intervençáo.

Deste modo,em função do fato das "recomendaçōes",pelo menos na área da Saúde Pública e da Educação em Saúde Pública constituirem, quase sempre, propostas de intervençāo, não é possível, aqui, como se faz habitualmente, listar um elenco de recomendaçōes.

E possivel ,no entanto,definir as grandes linhas de um conjunto interseccional que envolva investigação e intervenção.

Este conjunto seria composto por investigações/intervenções, seguindo o modelo da pesquisa-ação ou pesquisa participante ,que poderiam ser desenvolvidas em Centros de Saúde, Hospitais, Creches, Escolas, dentro ou fora do quadro dos projetos de Integraçāo Docente Assistencia (70).

Nessa linha,os seis temas agregadores podem constituir objeto destas investigaçōes/intervenções.

A título de sugestão - sem a pretençāo de esgotar o material temático levantado neste trabalho - sugerimos, além dos seis grandes temas agregadores, os seguintes temas e sub temas de pesquisa e/ou intervençāo:

- medicamento e alimentação : discussão/investigaçāo sobre os CAHPs associados aos dois objetos como mercadorias /símbolos de saúde em geral e em situações espećficas por exemplo: vitamina nas frutas $x$ vitamina nos remédios; dieta $\mathrm{x}$ medicamento na hipertensão. 
- os "loci" da saúde : discussão/ investigaçáo sobre os CAHPs associados aos diversos "loci" da saúde: na mente, no corpo, no objeto de saúde (entre eles, o medicamento), no social.

Parece claro que ,neste caso, poder-se-a combinar ,com resultados potencialmente interessantes, a perspectiva da Semiotica aplicada à saúde pública com a perspectiva que adota o modelo "Locus of Control".

- análise/intervençāo em torno dos CAHPs associados às expectativas-geradas socialmente- que cercam o medicamento visto como instrumento de "reposição imediata" da saúde e as repercuçōes disto na interção médico paciente.

- discussão/intervenção, tendo como população alvo os profissionais de saúde,sobre os usos extra terapêuticos do medicamento na prática clínica : o medicamento como símbolo ,para o profissional de saúde.

- discussão sobre a possibilidade de introdução ,na rede,de práticas alternativas de saúde dentro de um sistema social, de uma cultura e de um modelo de assistência de saúde decorrentes desta sociedade e desta cultura , que tem no consumo de objetos/ símbolo de saúde a sua pedra angular. Confronto entre: mercadoria alternativa, nova moda consumista $\mathrm{x}$ alternativa à mercadoria, nova perspectiva de sociedade, de cultura.(fatores que possibilitam).

Este conjunto interseccional pode dar lugar,no campo da Saúde Pública e da Educação em Saúde Pública,a uma ciência menos acadêmica e a uma prática menos emergencial que, por sua vez, podem dar nascimento a um terceiro caminho, situado entre estas duas polaridades que,sem negarem ( a ciência 
acadêmica é necessária e a prática emergencial também) estariam contribuindo para o enriquecimento da Saúde Pública como praxis *

\footnotetext{
"Afirma CANDEIAS (16) :" A interação entre a pesquisa e a prática representa assunto relevante na área de Saúde Pública,razão pela qual a utilização da pesquisa na prática e da prática na pesquisa exige e merece especial atenção por parte dos investigadores e profissionais de saúde, quando se visa a alcançar maior produtividade em ambos os setores" (pag. 11.).
} 
REFERÊNCIAS BIBLIOGRÁFICAS 


\section{REEERENCIAS BIBLIOGRAELCĀS}

1) ALTHUSSER.L. Idéologies et Aparreils Idéologiques d'etat. Paris, La Pensée, 151, 1970.

2) ALTHUSSER,L. et all. Dialética e Ciências Sociais. Rio de Janeiro, Zahar, 1967.

3) BARROS,M.B.A. Saúde e Classe Social: um estudo sobre Morbidade e Consumo de Medicamentos.Ribeirão Preto,FM/USP, 1983 (Tese de Doutoramento).

4) BARTHES,R. Mytologies. Paris, Seuil, 1957.

5) BAUDRILLARD,J. Le Systeme des objets: la consommation des signes. Paris, Denoel Gonthier, 1968.

6) BAUDRILLARD,J. Pour une critique de l'économie politique du signe.Paris, Gallimard, 1972.

7) BECKER,H.S. The Relevance of Life Histories. In DENZIN,N.K. Sociological Methods a Sourcebook. Chicago.Aldine Publs.,1970, pag.419-28.

8) BERLINGUER,G. Entrevista. IN: "PROPOSTA" RADIS-FIOCRUZ; 2, 11, 1988)

9) BODENHEIMER,T.S. La Industria Farmaceutica Internacional y La Salud de la Poblacion Mundial. Cuadernos Medico Sociales, 24: 21-35,1983.

10) BOLTANSKY,L. As. Classes Sociais e o Corpo.Rio de Janeiro, Graal, 1979. 
11) BOURDIEU,P. ET PASSERON,J.C. La Reproduction.Paris, Editions de Minuit, 1970.

12) BRUYNE,P. Dinamica da Pesquisa em Ciências Sociais (2a Ediçăo) Rio de Janeiro, Francisco Alves, 1977.

13) BUSH,P.J. E RABIN,B.L. Who's using nonprescribed medicines. Medical Care, 12: 14 - 1014-23, 1976.

14) CABRAL DE BARROS, J.A. A Medicalização da Clientela Previdenciaria. São Paulo, 1982. FMUSP (Dissertação Mestrado).

15) CALDEIRA ,T.P. A Politica dos outros. O cotidiano dos moradores da periferia e o que pensam do poder e dos poderosos. São Paulo, Brasiliense, 1984.

16) CANDEIAS, N.M.F. Educação em Saúde na Prevenção do Risco de Desmame Precoce. Sāo Paulo, FSP/USP, 1981 (Tese de Livre-Docencia).

17) CENEVIVA, B.M.P. Efeitos adversos: riscos da antibiótico- terapia. Ciência e Cultura, 3: 4 , 1985.

18) CHASSANGNON,CH. E MEYER,C. Reflexions sur la Pathologie Yatrogene. Médicine et Hygiene, 41: 2352-54, 1983.

19) CLEARY, H.P. Health Education: the role and functions of the specialist and the generalist.Rev. Saúde Publ.,São Paulo, 22 (1): 64-72, 1968.

20) COMO PERDER PESO E GANHAR SAÚdE: A DIETA IDEAL. Revista Manchete. 28/5/1988. 
21) COMAROFF, J. A Bitter Pill to swallow: Placebo Therapy in General Pratice Social.Rev., 76-96, 1976

22) "CONFESSE: DE VEZ EM QUANDO VOCE DA UMA DE MEDICO". Shopping Newz,City News. 27/5/1984.

23) CORDEIRO,H. A Industria da Saúde no Brasil. Rio de Janeiro, Graal, CEBES, 1980.

24) CHITWOOD,S. Cosmética Natural. (3a.ED). São Palo,Ground, 1987.

25) DANHIER, A. ET ALL. Prescripcion y Dispensacion de Quimioterapeuticos Boletin De La Oficina Sanitária Panamericana, 97 (6): 478-90, 1984.

26) DENZIN,N.K. Sociological Methods: a sourcebook. Chicago. Aldine Publs., 1970.

27) DIXON,B. Além das balas mágicas. São Paulo, T.A,Queiroz/ /EDUSP, 1981.

28) ECO,U. As formas do conteúdo. São Paulo, Perspectiva, EDUSP, 1974.

29) ECO,U. O Signo. (2a ed.), Lisboa, Presença, 1981.

30) ENCONTRO POR MELHORES CONDIÇÕES DE SAÚDE, 1. Textos De • Saúde Pública.APSP. São Paulo, 1983.

31) FRANCO,R.C.S. ET AL. Consumo de medicamentos em um grupo populacional da área urbana de Salvador-BA. Revista Baiana de Saúde Pública, 13/14 (4/1): 113121. $1986 / 1987$. 
32) GIOVANNI,G. A questâo dos remédios no Brasil: produçắo e consumo. Săo Paulo, Polis, 1980.

33) GOLDMAN,L. A reificaçăo das relações sociais.In: FORACCHI,M.M. \& MARTINS,J.S. Sociologia e Sociedade. Rio de Janeiro. Livros Técnicos e Cientfficos, 1980.

34) GRAHN,J.L. Relationship of consumers perception of drug to drugs use. Pub. Health Reports, 99 (1) 85-90-1983.

35) GREEN,L.W. ET ALL. Diretrizes para o componente educativo de Programa de Saúde Materno Infantil. Health Education. 21(3); 1978. (Trad. Mimeografado)

36) GRIFFITHS,A. Recours aux soins et consommation de médiquements. Rev. Epidem. Et. Santé Publique, 31: 73-98. 1983.

37) HAAK,H. Pharmaceuticals in two brazilian villages: lay practices and perceptions. Soc. Sci. Med., 27(12) .1415-1427. 1988

38) HAFEN,B.G. Medicine and drugs: problems and risks use and abuse. 2a. ed. Philadelphia. Lea and Febiger, 1978.

39) HORTON,J. Anomia e alienação: um problema na ideologia da sociologia. IN: FORACCHI,M,M, E MARTINS,L.S. Sociologia e Sociedade, Rio de Janeiro, Livros Técnicos e Científicos, 1980.

40) JAKOBSON,R. Essais de Linguistique Génerale. PARIS, 1963.

41) JOHNSON,R.E. ET AL Reported use on nonprescribed drugs in Health 
Maintenance. AM. J. Hosp. Pharm., 33: 1249-1254. 1976.

42) JOHNSON,R.E. Health Status and Social factors in Nonprescribed Drug Use. Med. Care, 21 (2): 223-225. 1983.

43) KOROLKOVAS,A. A poluição medicamentosa. O Estado de São Paulo, $3 / 6 / 1983$.

44) LAMDMAN,J. Evitando a saúde e promovendo a doença (4a. ed.) Rio de Janeiro.Ed.Guanabara. 1986.

45) LEFEVRE,F. A oferta e a procura de saúde imediata através do medicamento: Proposta de um campo de pesquisa. Rev. Saúde Pública, S.Paulo, 21(1): 64-7, 1987.

46) LEFEVRE,F. A função simbólica dos medicamentos. Rev. Saúde Pública, 17, 500-3, 1983.

47) LUDKE,M. E ANDRE,M.E.D.A. Pesquisa em educação, abordagens qualitativas. São Paulo, EPU., 1986.

48) LUZ,M.T. As instituiçōes médicas no Brasil. Rio de Janeiro, GRAAL, 1979.

49) MACRORIE,R. Maaman's Dilemma: factors influencing thecompliance of patiens to prescribed drugs in Chronic Diseases With Particular Reference to Leprosy.Lepr.Rev. 52 (2): 143-152, 1985.

50) MAGALDI,C. Políticas de Saúde no Brasil. Mimeo.

51) MELROSE,D. Anarquia nas farmácias. Notícias PROCON, 1 (6) 1985. 
52) METZ,C. Langage et cinema. Paris, LAROUSSE, 1970.

53) MICHEL,J.M. Why people like medicines? A perspective from Africa. LANCET, 1 (8422), 1985.

54) MORAES FILHO,J.P. \& BONBONATTI,T.A. A Ação Transcendente Dos Medicamentos. Rev. Bras. Clin.Terap., 15, 264- 265, 1986.

55) "NA PUBLICIDADE, REDATOR DEVE TRANSFORMAR PRODUTO EM DESEJO". Folha de São Paulo, 15/3/1987.

56) PEREIRA,J.C. Medicina, Saúde e Sociedade. In: Estudos de Saúde Coletiva - 4. Rio de Janeiro, ABRASCO, 29-37.1986.

57) PECK,C.L E KING,N.J. Compliance and the doctor - patient relationship. Drugs, 30: 78-84, 1985

58) PIERCE,C.S. La ciencia de la semiotica. Buenos Aires. Nueva Vision, 1974.

59) PIERCE,C.S. Semiotica e filosofia. (2a ED.), São Paulo. CULTRIX/EDUSP, 1975.

60) PILON,A.F. Desenvolvimento da educação em saúde: uma atualizaçāo de conceitos. São Paulo. Faculdade de Saúde Pública, mimeo.

61) QUEIROZ, M.S. O paradigma mecanista da medicina ocidental moderna:uma perspectiva antropológica. Rev. Saúde Pública. 20 (4): 309-17, 1986.

62) QUEIROZ,M.P. Histórias de vida e depoimentos pessoais. Sociologia, 15 (1): 8- 
24, 1985.

63) QUEIROZ,M.P. Relatos orais: do "indizfvel" ao "dizfvel". Ciencia e Cultura, 39(3), 272-286, 1987.

64) RAW,I. Labirinto de remédios. Revista VEJA, 19/8/1987.

65) SÁ,D.B.Drogas/seus estímulos. Jornal do Brasil, 1/12/86.

66) SALLES,J.M. Efeitos adversos do uso de antibióticos. Hilea Médica. Belém, 3 (1): 3-27, 1981.

67) SANTAELla,L O que é semi6tica. (5a Ed.), Sāo Paulo. Brasiliense, 1987.

68) SANI,A.C.O.B. Intoxicaçāo crônica causada por analgésicos. Jornal do C.R.F., 8 (124), 1985.

69) SASSAKY,T.H. Prescrição: uma análise institucional. São Paulo. Fac. Saúde Pública/USP, 1984 (Tese de Doutoramento).

70) SILVA,M.E.L. Entrevista aberta.USP/FSP,Mimeo.

71) SIMÕES,M.J. e FARACHE FILHO,A. Consumo de medicamentos em região do Estado de São Paulo (Brasil), 1985. Rev. de Saúde Publ., S.Paulo, 22 (6): 494-9, 1988.

72 SOUZA, A.M.A. Integração docente assistencial. Mimeo, 1984

73) SZYLLEJKO,OJ. The use of unprescribed medicine in warsaw during the years 
1970-1980. Drug intelligence and clinical pharmacy, 18 (9), 1984.

74) TEMPORĀO,J.G. A propaganda de medicamentos e o mito da saúde. Rio de Janeiro. GRAAL, 1987.

75) "TODO REMÉDIO E VENENO". Vida Integral, Julho, 1987.

76) TODOROV,T. ET ALL. Linguagem e motivação: uma prespectiva semiológica. Porto Alegre, Globo, 1977.

77) UM GOLPE DA CIENCIA NA RAIZ DA DOR. Revista Veja.19/10/1988.

78) USO INDEVIDO DE ANTIBIOTICOS. Bol. Epidem., 14 (26): 273- 277, 1982

79) VERON,E. A produção do sentido. São Paulo CULTRIX EDUSP, 1980.

80) WAITZKIN,H. The micropolitics of medicine: a contextual analysis.IN: Journ of Health Services, 14 (3),1984.

81) WAITZKIN,H. Information Giving In Medical Care.J. Health. Soc. Behav., 26 (2), 1985

82) WOLPE,P.R. Medicine, Technology, and lived relations. Perspect Biol. Med., 28 (2), 1985. 
ANEXO 1 
Roteiro de Entrevista Semi Aberta com Pacientes Hipertensos 
A) Apresentaçăo da pesquisa e do pesquisador.

1) Como e quando você descobriu que é hipertenso?

2) Para você que 6 hipertenso, o que o remédio significa em sua vida?

3) Se tivesse que escolher:mexer na alimentação ou tomar remédio, qual escolheria e porque?

4) Como é ,para você, ter que tomar remédio a vida toda?

5) Você acha que acontece alguma coisa com você se deixar de vez em quando de tomar o remédio?

6) Porque o remédio consegue baixar a sua pressão?

7) O que é mais importante para você: o remédio ou o médico? Porque? 


\section{B)Identificaçăo:}

- idade

- bairro

- estado civil

- tipo de residência : alugada, própria,cedida

- atividade no momento

- ocupação do cônjuge

- renda familiar (aproximada) 
ANEXO 2 


\section{MATERIA DOCUMENTAL}

- "Slogan"da campanha anti-polio.

- Capa da Revista "Saúde".

- Propaganda da Amico.

- Propaganda "Saúde Total"(jornal).

- Propaganda "Turismo Saúde"(jornal).

- Propaganda em farmácia.

- Propaganda da "Termo Gel" (ônibus).

- "Slogan" da Blue Life (propaganda de rádio).

-"Slogan" da Amil (propaganda de televisão).

- Adesivo da Golden Cross.

- Adesivo da Saúde Bradesco. 
- Sub título da Revista Pais e Filhos.

- "Slogan" de Yacult (propaganda de televisåo).

- Artigo da Revista Manchete.

- Folheto publicitário da Bio da Danone.

- Folheto publicitário das cápsulas de óleo cru de fígado de bacalhau e óleo de germe de trigo.

- Folheto publicitário das vitaminas Fontovit.

- Publicidade do medicamento "Cytotec" (periódico).109

- Publicidade do medicamento "Iloban" (peródico ).

- Propaganda de produto homeopático para emagrecer..

- Publicidade de "Fibrapur" (periódico )

- Publicidade do medicamento "Tamarine" (periódico ).

- Publicidade do medicamento "Florantil" (perídico).

- "Slogan" publicitário do medicamento "Doril" (várias midias) 
- Publicidade do medicamento "Ladogal" (periódico).

- Publicidade do medicamento "Mio-Citalgin" (periódico).

- Publicidade do medicamento "Dexa-citoneurin" (peri6dico).

- Publicidade do medicamento "Flanax" (periódico).

- Publicidade do medicamento "Buferin" (periódico).

- Publicidade de anti-ácido(propaganda de televisão).

- Publicidade de medicamento contra torcicolo (propaganda de televisão).

- Publicidade de pastilha contra tosse (propaganda de televisão).

- Quatro depoimentos de clientes do Centro de Saúde Geraldo de Paula Souza (fase de pré teste do formulário).

- Bula do medicamento "Binotal". 
ANEXO 3 
em Paris, a Danone

selecionou, entre vários

CONHEÇA BIO POR DENTRO.

Bio de Danone representa uma nova geraçào de produtos láctens frescos

Bio é um leire

naturalmente fermentado. através do microorganismo Bifidobacterium, comercialmente conhecido como Bifidus Alivo.

Após profundas pesquisas no campo da microbiologia. desenvolvidas no Cento Intemacional de Pesquisa Daniel Carasso*. lipos de Bifidobacterium, a especie longum, mais adap lada a seus produtos $e$ às necessidades dos consumidores

O Bifidus possui a característica de ser atjvo no organismo. sendo que a espécie longum resiste melhor à passagem pelo ambiente ácido do estómago Ele permanece vivo. ativo e numeroso. fixando-se posteriormente no intestinu. onde exercerá suas propriedades benéficas ao homem, pois adapta-se perfeitamente à temperatura do $\operatorname{cor} 0$, de $37^{\circ} \mathrm{C}$

O Bifidus Alivo é conhecido pela sua alta característica imunológica em relaçāo às infecçōes intestinais, uma vez que ele está presente nomalmente no leite matemo.

- Danjel Carasso $t$ fitho do fundador da

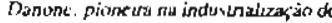
ugure ne mundo nrodem.

\section{BIO AJUDA A DIGESTÃO E PROTEGE A FLORA INTESTINAL.}

A nora láctica viva do $B$ io de Danone faciliti a digestáo, pois apresenti proteínas pré-digeridas, que melboram o tránsito gastrico e o ben-estar digestivn
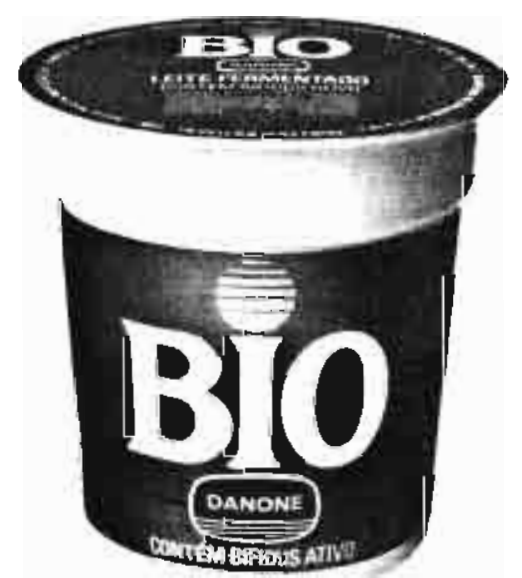

Bio de Danonc atua:

- na regulagem do trânsito intestinal:

- na proteçáo da flora intestinal:

- na reposiçāo da flora após tratamento com antibiólicos:

- no combate à constipaçáa e diarréia:

- na inibiçāo da proliferaçáo de gemes patogênicos;

- na desintoxicaçāo inlestinal.

Bioé altamente nutritiv ajuda a melhor assimilaçā do ferro no organismo. além de ser excelente font de cácio e proteinas de alta qualidade, o que favorece a mineralizaçāo ossea. 


\section{PRODUTOS NATURAIS DE ALTA QUALIDADE}

\section{Cápsulas de}

ÓLEO DE ALHO CRU ÓLEO DE FIGADO DE BACALHAU OLEO DE GERME DE TRIGO

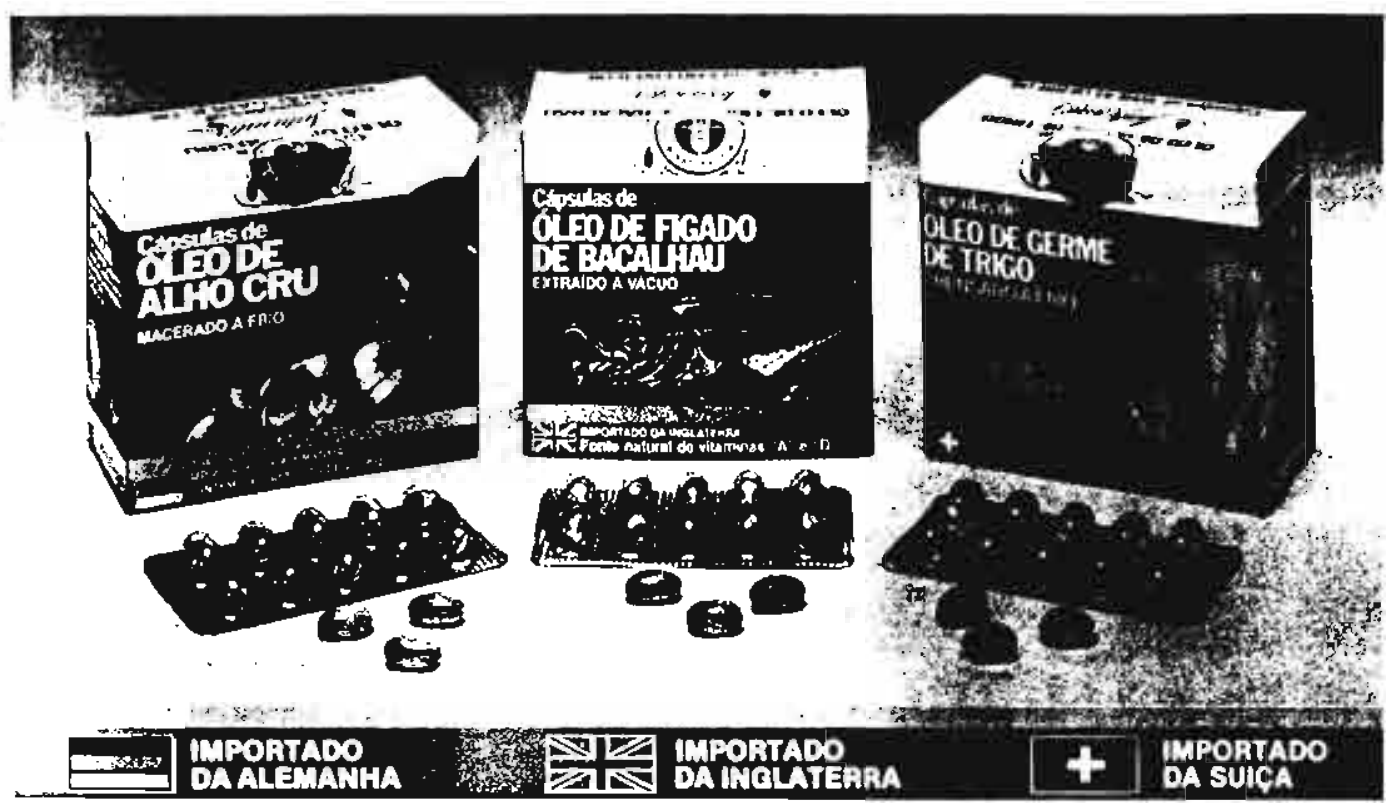

\section{O SEGREDO DA VIDA LONGA E SAUDÁVEL}

A antiga expressão "Vocé tem a ida. de de suas arterias" seguramente é válida hoje e será sempre. De fato, artérias elásticas e pulsantes, livres de depósitos de gorduras, garante uma circulação ativa do sangue para alimentar adequadamente as células com oxigénio e nutrientes que prolongam sua vida útil, promovendo assim maior longevidade para todo nosso corpo.

O Olleo de Alho Crú, o Óleo de Germe de Trigo e o Óleo de Flgado de Baca-
Ihau Naturalis, ricos em nutrientes nobres, tém ação protetora sobre as artérias e proporcionam melhor nutrição e oxigenação das células, evitan. do desta forma os fatores que determinam o envelhecimento precoce do nosso organismo.

Com o firme proposito de apresentar sempre o máximo em qualidade, a NATURALIS está Importando estes produtos diretamente de fontes sele cionadas na Europa, consideradas as melhores do mercado mundial. 


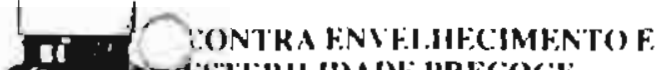

- TSTERIIIDADE. PRECOCF.

Previne o envelhec imento precece evilander oxidaçás prematura das células. prolongundos. assim, suas vidas üleis. Protege contra afeçioes neuro-musculares. Impede a degenere scència testicular e cspermática, a atrofia dos canais seminais, a azoospermia e a esterilidade precoce

FACILITA A DIGFSTẢo. Enzima extraldo do látex do mamáo, é excelente coadjuvante da dizestán. Transforma as proteínas ingeridas em amino-ácidos essenciais so organismo.

eliminando, concomitantementc. as sensaçoos vivos, faz parte da Natureza. Ele é a própria Natureza e dela breviveu por milênios. Foi nsumindo substâncias naturais que creveu sua história no Universo. istoria que nos mostra a vitamina mo substância natural que equilibra funçóes vitais do organismo. as vitaminas, para que sejam cazes, devem ser tomadas puras e h doses certas. sim sāo as vitaminas naturais PNTOVIT, produtos puros, dosados laborados com alta tecnologia para tirar da Natureza só o que ela tem de m. constituinte importante das células do cérebro e

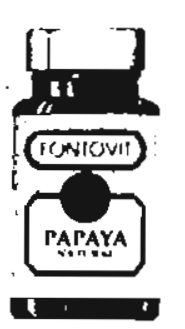

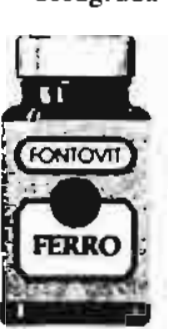

CONTRA ANEMIAS.

Constituinte essencial dos glóbulos vermelhos do sangue, previne anemias fortalecendo o sangue. Indicado inclusive nas menstruaçóes abundantes e prolongadas.

FACILTTA A QUEIMA DE GORDURAS. Agente lipotrópico, distribui homogeneamente as gorduras do organismo, evitando sua deposiçáo em apenas algumas regiỏes, conseqüeniemente facilitando sua queima. Previne a queda de pèlos e cabelos provocada por dermatites. E de todo o sistema nervoso.
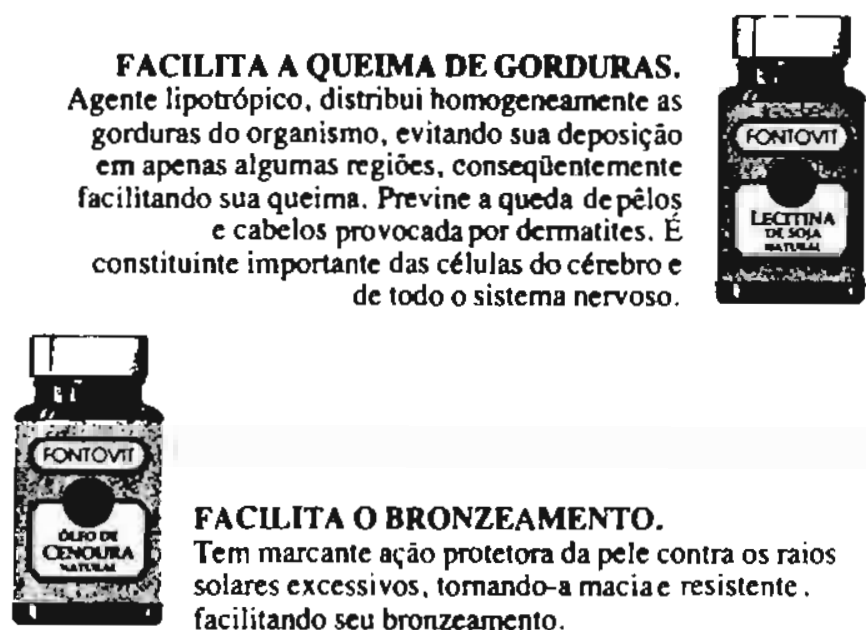

FACILITA O BRONZEAMENTO Tem marcante ação protetora da pele contra os ráios solares excessivos, tomando-a maciae resistente. facilitando seu bronzeamento.

PARA O SISTEMA NERVOSO. Fonlc natural da vitamina $E$. por sua açăo anti-oxidante protege as células do cérebro, do sistema nervoso

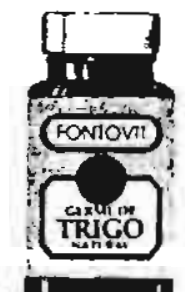

EMBF.LEZA A PELE.

Contém 4nog do seu pesn em priteínas escenclas ao desenvolvimento c manutençio do organismo animial, além de se consuituir na maior fonte narural das vitaminas do complexo $B$. Complemento importante pora normalizacio des funçöes inteslinais. Melhon a pek

COMBATE A FADIGA FISICA. MENTAL E SEXUAL. Obtido das raizes da planta asiática "Panar ginseng": indicado nos casos de debilidade ffsica. mental e das funçōes vitais do organismo incluindo-se as da esfera sexual. Combare a fadiga. a hipotonia c a neurastenia.
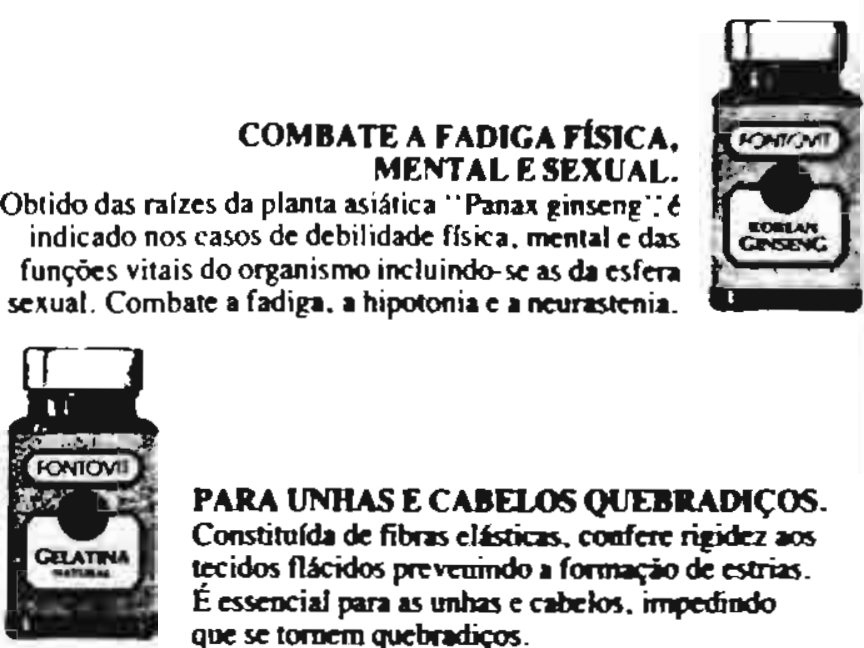

PARA UNHAS E CABELOS QUEBRADIÇOS Constitulda de fibres el terioss, confere rizidez as tecidos flácidos pre veumdo a formacio de estrias. É essencial para as untras e cabelos. impedindo que se tornem quebradicos.

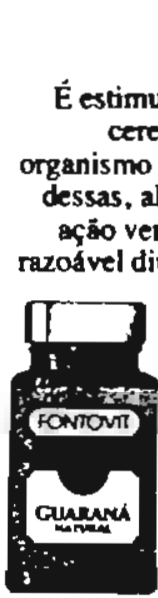

ATVA A MEMÓRIA E FREVTE RESTRIADOS. estimulante da circulaçio sanquifnea perifterica $e$ cerebral ativando a memoria e coaferindo wo

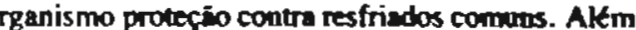
ssas, alguns dos seus constituintes térn matante acho vermicids, eliminando vermes intestinuis. $\mathbf{E}$

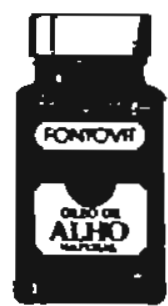

TÔNICO VTTALIZANTE

Com marcante acio energtica e vitalizante conferte ao organismo sensaçäo de bem esta e vitalidede. Normalizador das funçōes intestimais $t$ administrado tambem como cometor da prisio de ventere.

PARA PELE, VISÃO E CONSER VACÁO DOS DENTES. É a responstuvel pela elasticidade e miriez di pele. Sem ela, a pele se torma ispera. quetradica $\mathrm{c}$ sajeito a micoses e eczemes. Imprescindivel para minorar os efeilos da cegueira notuma. Ammaztiada no fizado. protege-o contra intoxicaçoes. normalizando inchusive a secreçäo scidl do estômigo. Na criança, controlta o 

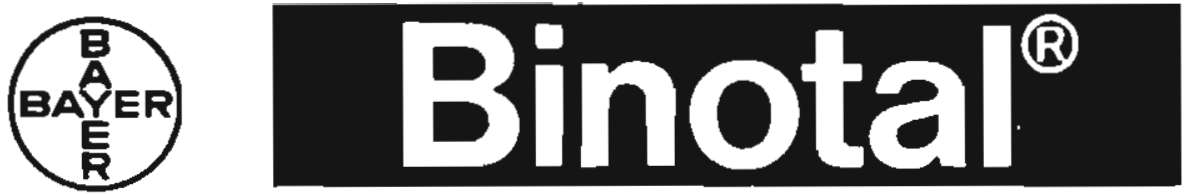

Ampicilina triidratada - Ampicilina sódica

\section{INDICAÇOES E PROPRIEDADES}

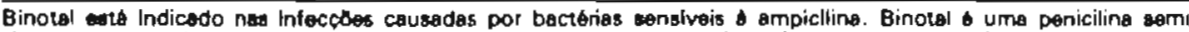

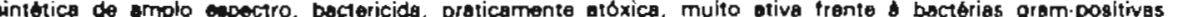
grem-nogativas.

\section{APRESENTACAO E COMPOSICAO}

Formas orala - Compoalça: Ampicllina

Cópsulas $250 \mathrm{mg}$. caixas com 12 cApsules $(250 \mathrm{mg})$. Copsulas $500 \mathrm{mg}$. coixas com 6 a 18 cápsulas $(600 \mathrm{mg})$ Comprimidos $250 \mathrm{mg}$. colxes com 12 comprimidos $(250 \mathrm{mg}$ ). Comprimidos $500 \mathrm{mg}$. caixes com 6.18 comprimi-

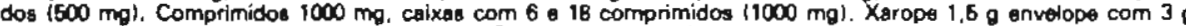
de granuledo e vidro com $58 \mathrm{ml}$ de diluents $(125 \mathrm{mg}$ por $5 \mathrm{mll}$. Xarope 3.0 g envelope com 6 a de granulado vidro com $66 \mathrm{ml}$ de dluente $250 \mathrm{mg}$ por $5 \mathrm{ml}$ )

Formas injoturets - Camposiço: Amplefline

Frasco ampola 0.25 g. calxas com 25 le asco ampolas de $0.25 \mathrm{~g}$ - 25 ampalas de $2.5 \mathrm{ml}$ de agui nara miecáo 40.25 al Frasco ampola 0.5 g. caxes com 1 lesco-ampola de $0.59+1$ ampala

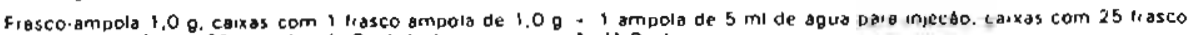

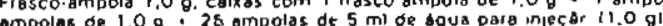

\section{CONTRA-INDICACOES. PRECAUÇOES E EFEITOS COLATERAIS}

- Hipersensibilidade a penicilina ou derivados e As cefolosporinas

- Disturbios gestrointestineis leves e ocasionais regridem espentaneamente com a interrupcao da mediceça, ou masmo com a sur continuaço.

POSOLOGIA E MODO DE USAR

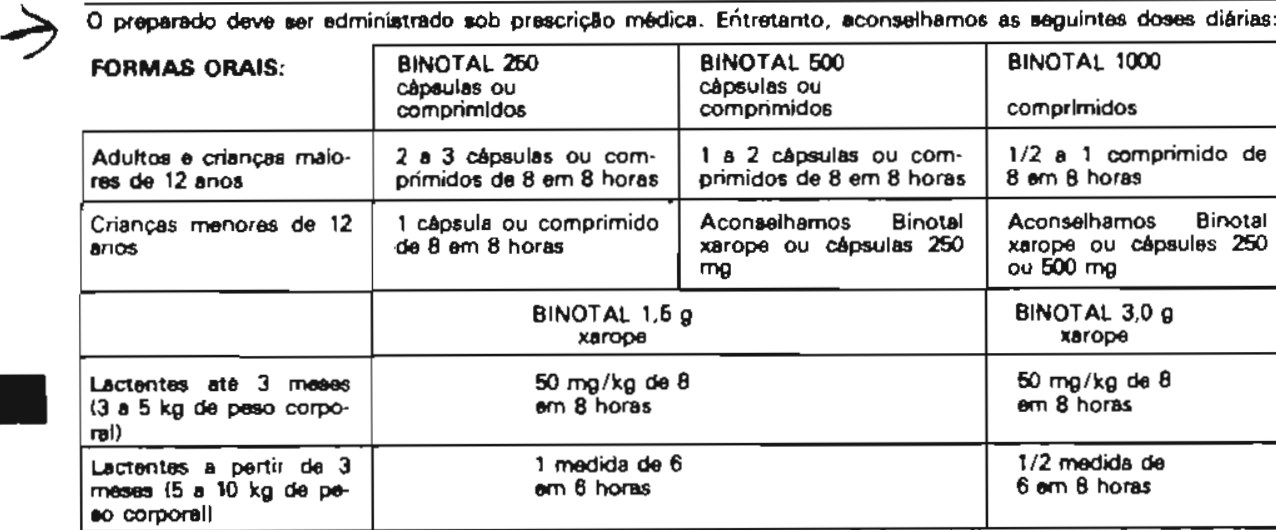

